\title{
When Two Worlds Collide: Norval Morrisseau and the Erotic
}

\section{A thesis submitted to the Faculty of Graduate Studies and Research in the partial}

fulfillment of the requirement for the degree of Master of Arts.

Faculty of Arts and Social Sciences

Carleton University, Ottawa, Canada

By Michelle McGeough
March 2006

(C) Michelle McGeough 


$\begin{array}{ll}\begin{array}{l}\text { Library and } \\ \text { Archives Canada }\end{array} & \begin{array}{l}\text { Bibliothèque et } \\ \text { Archives Canada }\end{array} \\ \begin{array}{l}\text { Published Heritage } \\ \text { Branch }\end{array} & \begin{array}{l}\text { Direction du } \\ \text { Patrimoine de l'édition }\end{array} \\ \begin{array}{l}\text { 395 Wellington Street } \\ \text { Ottawa ON K1A 0N4 }\end{array} & \begin{array}{l}\text { 395, rue Wellington } \\ \text { Ottana ON K1A ON4 } \\ \text { Canada Oa }\end{array}\end{array}$

Your file Votre référence ISBN: 978-0-494-23308-5 Our file Notre référence ISBN: $978-0-494-23308-5$

NOTICE:

The author has granted a nonexclusive license allowing Library and Archives Canada to reproduce, publish, archive, preserve, conserve, communicate to the public by telecommunication or on the Internet, loan, distribute and sell theses worldwide, for commercial or noncommercial purposes, in microform, paper, electronic and/or any other formats.

The author retains copyright ownership and moral rights in this thesis. Neither the thesis nor substantial extracts from it may be printed or otherwise reproduced without the author's permission.
AVIS:

L'auteur a accordé une licence non exclusive permettant à la Bibliothèque et Archives Canada de reproduire, publier, archiver, sauvegarder, conserver, transmettre au public par télécommunication ou par l'Internet, prêter, distribuer et vendre des thèses partout dans le monde, à des fins commerciales ou autres, sur support microforme, papier, électronique et/ou autres formats.

L'auteur conserve la propriété du droit d'auteur et des droits moraux qui protège cette thèse. $\mathrm{Ni}$ la thèse ni des extraits substantiels de celle-ci ne doivent être imprimés ou autrement reproduits sans son autorisation.
In compliance with the Canadian

Privacy Act some supporting forms may have been removed from this thesis.

While these forms may be included in the document page count, their removal does not represent any loss of content from the thesis.
Conformément à la loi canadienne sur la protection de la vie privée, quelques formulaires secondaires ont été enlevés de cette thèse.

Bien que ces formulaires aient inclus dans la pagination, il n'y aura aucun contenu manquant. 


\section{Abstract:}

Norval Morrisseau, the founder of the Woodlands School of painting, has painted thousands of canvases in a career that spans five decades. Throughout his career he has consistently created and added to a body of erotic work that is seldom, if ever, viewed by the general public. My inquiry into his erotic depictions stems from a desire to determine what these images reveal about how sexuality is considered in the worldview of the Anishnaabe people in comparison to that of Euro-Canadians.

I argue that Norval Morrisseau's erotic depictions appear to replicate EuroCanadian patriarchal representations of the body, but from another perspective they are also informed by and reflect an Anishnaabe worldview. They are thus sites of resistance that critique and question sexual hierarchies, social divisions and western mythologies that control and manage sexuality and pleasure. Drawing on the writings of contemporary Anishnaabe scholars and the oral tradition of the Anishnaabe people, I compare and demonstrate the fundamental differences between these two worldviews in relation to sexuality and desire. To this end I contend that because Norval Morrisseau's erotic depictions demonstrate a different way of knowing and looking, western mythologies regarding sexuality and desire are revealed as being historical developments that over time have been transformed to appear naturalized. 


\section{Acknowledgements:}

There are always so many people to thank for their assistance and guidance whenever one undertakes such a task as this, and many individuals who were generous and giving of the time, support and encouragement. First and foremost I wish to thank Norval Morrisseau for sharing his vision. I am very grateful to Gabor and Michele Vadas for their time and willingness to meet with me. I also wish to extend my gratitude to my advisor Dr. Ruth B. Phillips, whose patience, encouragement and insight contributed to this endeavor more than I can ever express. I also wish to acknowledge my thesis defense committee for their insight. Many thanks go to Amy Rose and Ann deStecher, for proofreading the painfully disorganized and random thoughts. Agnes Huang's combination of brilliant mind and word smithing were a godsend and saved my sanity. To Maria Victoria Guigetti, I owe many thanks for listening to my many diatribes on theory, and also to Rosalie Favell for just listening. To my colleagues, thank you for the stimulating conversations and reminding me of why we do this. Thanks to Mickey Fry who through his determination and focus was an example to me. To my Family I thank you for your words of encouragement, the laughter and love. Most of all I wish to acknowledge two ordinary people who lived extraordinary lives; my parents, who know of worlds I can only visit in my dreamings. 


\section{Table of Contents:}

List of Illustrations

Chapter 1: Introduction

Chapter 2: The Female Nude

Chapter 3: The Male Nude

Chapter 4: The Alternative

Chapter 5: The Conclusion

Appendix A

Bibliography $v-v i$

$1-24$

$25-45$

$46-70$

$71-91$

$92-95$

$96-116$

$117-122$ 


\section{List Of Illustrations:}

Figure1.1 Artist in Union with Mother Earth (1972), Acrylic on canvas. $77.5 \mathrm{~cm} \mathrm{x}$ $116.8 \mathrm{~cm}$,. Private Collection M. Mason. Toronto, Ont. Reproduced from

Figure1.2 Man and Woman( n.d.) 187.9 x 137.2.Acrylic on canvas. Glenbow Museum Collection. Calgary, Alberta .986.226.16

Figure 2.1The Great Spent Mother: Mother of All Serpents (1972) Acrylic on paper $37.8 \mathrm{~cm}$ x $50.2 \mathrm{~cm}$.. Royal Ontario Museum Collection

Figure 2.2 Medicine Wheel. Reproduced From D'Arcy Rheault. Midéwiwin Organization of Knowledge. Unpublished FC 500 Paper.Trent University, January 1997

Figure 2.3 Temptation and Fall (1510) Fresco, Michelangelo. Sistine Chapel, Vatican, Rome

Figure 2.4 Mother Earth (1975) Acrylic on canvas. Private Collection. Reproduced from the book. The Art of Norval Morrisseau. Page 124

Figure 2.5 Virgin Mary with Christ Child and St. John the Baptist (1973) $101.6 \mathrm{~cm} \times 81.3 \mathrm{~cm}$. Acrylic on canvas. Department of Indian Affairs Indian Art Centre. Reproduced from the book The Art of Norval Morrisseau. Page 101

Figure 2.6 Artist Wife and Daughter(1975) Acrylic on masonite. $101.6 \mathrm{~cm} \times 81.3$ $\mathrm{cm}$. Reproduced from the book The Art of Norval Morrisseau. Page 123

Figure 2.7 Woman. Circa 1960 Acrylic on canvas. Reproduced from the exhibition catalogue Norval Morrisseau and the Development of Woodland School of Painting. Maslak McCleod Gallery 2000. Page 17

Figure 3.1 Self Portrait of Indian Artist.(1985)Acrylic on canvas. Art Gallery of Hamilton Collection. 85MOR114 \#87

Figure 3.2 Phintias Satyr and Nymph (c510). Detail of red figure cup Badisches Landesmuseum, Karlsruhe. Reproduced from Abigial SolomonGodeau's Male Trouble: A Crisis in Representation. Page 181

Figure 3.3 Phallic Figure. Petroglyph (n.k.) Reproduced from the book Sacred Art of the Algonkians: A Study of the Peterborough Petroglyphs by Joan and Romas Vasokas. Page 84 
Figure 3.4 Untitled(1990's) Ink on paper. Private Collection of Gabor and Michele Vadas. Nanaimo, B.C.

Figure 3.5 Petroglyphs Shaman (n.k.) Reproduced from the book Sacred Art of the Algonkians: A Study of the Peterborough Petroglyphs by Joan and Romas Vasokas. Page 91

Figure 3.6 Man Changing into Thunderbird (1958-60). $63 \mathrm{~cm} \times 101.3 \mathrm{~cm}$ Watercolour and ink on birchbark. Canadian Museum of Civilization. Hull, P.Q. III-G-1099

Figure 3.7 Phallic God in Disguise (1972) Acrylic on canvas. Reproduced from the book The Art of Norval Morrisseau. Page 69.

Figure 3.8 Untitled (n.k.) Acrylic on canvas. Private Collection of Gabor and Michele Vadas. Nanaimo, B.C.

Figure 4.1 Indian Erotic Fantasy (n.d.) Acrylic on canvas. $257.8 \mathrm{~cm} \times 152.4 \mathrm{~cm}$ Glenbow Museum Collection. Calgary, Alberta. 986.226.35

Figure 4.2 Life Figures (n.k.) Acrylic on canvas. Art Gallery of Hamilton. 85MOR117 \#81

Figure 4.3 Untitled (1999) Ink on paper. Private Collection of Gabor and Michele Vadas. Nanaimo. B.C. 


\section{Preface:}

I heard Coyote outside the window of my apartment last night. I shouldn't be surprised -after all this is Ottawa -and every time I pick up the newspaper, I see her handy work in the headlines. I really don't mind her coming to visit and it's not that coyote is that bad. She is kind of like the relative who wears animal skin prints, big hair and leaves bright red lipstick stains on your coffee cups and the side of your face. She is a part of your life and there isn't too much you can do about it.

One of the nice things about living in an old house converted into apartments is that each room has some character, and other than pipes that rattle the only draw back is the lack of sound proofing. In my building you can hear someone coming up the stairway as soon as they open the front door, which can be advantageous especially if your personality leans towards the antisocial side of the continuum, which I must admit I sometimes occupy. I always make a conscious decision as to whether or not I will answer a knock on the door, because of this I have long since mastered the art of silencing myself and willing my body to not betray my presence on those anti -social occasions .

The night Coyote knocked on my door was one of those occasions. As I stood behind the closed door I suddenly saw flashes of light, like small firecrackers as everything around me began to melt. I realized that I had been holding my breath as I felt myself falling unable to stop the rush of the floor, my last coherent 
thought was. "Shit there is no way she didn't hear that." I had no idea how long I was out for but when I came to Mickey was licking my face, and his distant relative, Coyote was banging on the other side of the door.

"Is everything ok in there?" I heard her ask.

I slowly got to my knees and moved toward my fate. I opened the door. Silently hoping she wouldn't be staying too long, but I knew better. At first I saw the grin on her face, then my eyes slowly wondered down the length of her body and stopping at the two suitcases by her feet. I kidded myself that the size of the suitcases was not an indication of the intended length of her stay.

"Hi there" was all she said as she bounded forward and embraced me in a death grip. I found myself once again struggling for my breath.

"l' $m$ in town for a couple of days." she continued, brushing by me, as she left her suitcases in the hallway for me to claim.

Picking them up, I followed her into my own home, thinking to myself, what was Coyote up to?

My progress towards the guest room was blocked. Something on my desk had caught Coyote's attention, a computer print out of a painting from my desk. She turned toward me and waved the image under my nose.

"So, I see you what you do in your spare time," Coyote said in a mocking tone Dropping one of the suitcases at my feet, I reached for the image of the nude painting and grabbed it out of her hand. Placing it back on top of its' proper file. I replied 'it's not a hobby, it's part of my research on Norval Morrisseau's erotic artwork." 
"Hmmm," she said, "You can get a degree in that?"

I felt a little defensive and I heard it in my reply. "It's actually a degree in art history." I told her.

"Oh," she said, moving her head up and down, "And you got a scholarship to study this art history."

I was not sure if she was being sarcastic, asking a question or stating a fact at that point.

But I snapped "Yes, so what is your point? My frustrations were evident. "Jeese, I was just teasing." she said.

I felt guilty and contrite about my display of frustration so I explained, "Look, I'm sorry," I said as I pointed to the piles of images. "I know that these aren't just erotic images, there's something very different about them." I laid a dozen or more images out for her to see. "I have been looking at this work and trying to uncover a key or a pattern that will give me some idea about what Morrisseau is trying to say in his erotic depictions." I told her.

Coyote picked up an image from the pile, and she looked at it for a moment. She nodded her head up and down then placed the image back down on the desk. "What do you mean"? she asked.

I said to her, "Well, you know how South Asian Indian art has the tradition of the Kuma Sutra, and African art has the tradition of the phallus. "Well, I am trying to figure out what erotic tradition does Aboriginal art has?

As the statement came out of my mouth I could see Coyote breaking into a grin so big I thought her face would disappear, all I saw was teeth. She reached out 
and put a hand on my shoulder, leaning forward as she looked into my eyes. I sensed her mirth when she said, "Darling, what we have is an oral tradition." "What do you mean"? I asked her. I was unsure if she was just making a really bad joke or if there was some merit to what she was saying.

She must have sensed my confusion because she took my hand and led me towards the couch saying, "Come sit down, I have a few stories to tell you...." 


\section{Introduction: When Two Worlds Collide: Norval Morrisseau and the Erotic.}

Whatever is unnamed, undepicted in images, whatever is omitted from biography, censored in collections of letters, whatever is misnamed as something else, made difficult-to-come-by, whatever is buried in the memory by the collapse of meaning under an inadequate or lying language — this will become, not merely unspoken, but unspeakable. ${ }^{1}$

Adrienne Rich

Norval Morrisseau's contributions to the art world are monumental. As the founder of the Woodlands School of painting, and as the initiator of a career that has spanned five decades, his influence is visible in the artwork of generations of Aboriginal artists. Throughout his career he has consistently created and added to a body of erotic work, but this genre of his artistic practice has until recently been largely ignored. Historically, Aboriginal people did not consider the erotic as a separate category of expression as it is within the Euro-Canadian artistic tradition. Rather oral traditions often incorporated what Europeans considered erotic elements. Morrisseau's depictions of the legends early in his career reflect his awareness of this traditional approach.

It is difficult to determine how many erotic works by Morrisseau exist. He was by all accounts a prolific painter especially in the early years of his career, ${ }^{2}$ but he has explored both the female nude and the male nude throughout his career.

1 www.womenshistory.about.com./cs/quotes/a/qu_adrienerich.htm. Accessed10.02.2006

2 This is especially problematic as Morrisseau did not document many of his paintings and no records appear to have been kept with the exception of 
These works raise some very interesting questions regarding the ideologies and assumptions embodied by the nude. It is my contention that Norval Morrisseau's erotic imagery makes visible notions of the body, sexuality and gender very different from those of the mainstream, which reflect western European sensibilities. I argue that Morrisseau's depictions of the erotic unmask and challenge the authority of mainstream society's meta-narratives regarding the body, sexuality and gender.

\section{Western Theory}

Throughout this thesis I have utilized key western theorizations to both illustrate the historic development of western notions of sexuality and gender and how these notions have become part of mainstream meta-narratives. I use western theory to demonstrate how western ideas of the body, gender and sexuality are embodied in western representations of the nude. The theories of Michel Foucault and Roland Barthes demonstrate that these representations are historical constructs and reflect a particular worldview. By juxtaposing Morrisseau's interpretation of the nude, I reveal how his depictions are capable of revealing a different understanding. Using writings by Anishnaabe ${ }^{3}$ and nonAnishnaabe scholars regarding the Anishnaabe worldview, my analysis of Morrisseau's imagery confirms that Morrisseau's depiction of the nude has it roots firmly established in an Anishnaabe worldview.

those by his agents.

3 Anishnaabe, Ojibwa, Ojibway and Chippewa refer to the same group of people. They speak a language that belongs to the Algonquian language family. Ojibwa is a common term in Canada while Chippewa is more commonly used in the Untied States. Anishnaabe is the term the people use to describe themselves. 
Michel Foucault's work on the construction of sexuality and gender has been particularly important. Foucault writes in the History of Sexuality (1990), that prior to the rise of the bourgeoisie the ruling class justified its control and power by the formation of alliances; one's power was determined by one's bloodline. ${ }^{4}$ The deployment of sexuality was a way in which the bourgeoisie marked and maintained its distinctiveness from other classes. With the rise to power of the middle class in Europe in the 17th Century the power over life and death formerly held by the aristocratic lord over his vassals was replaced with a power over life exercised by the middle class in the interest of self-affirmation and preservation. The controls placed on sex were intended to ensure the bourgeoisie's health and longevity. Sex became something to be approached calmly and with control, to be studied rationally, and to be analyzed and classified. As Foucault states, this control was deployed in four areas: the sexuality of children, women, married couples and the sexuality "perverse." Sexual desire became something to be controlled and regulated. Foucault writes: "The society that emerged in the nineteenth century...put into operation an entire machinery for producing true discourse concerning it [and] also set out to formulate the uniform truth of sex. ${ }^{66}$ This resulted in a prescriptive delineation of the kinds of sensations and pleasures that were permissible and not permissible as well specific definitions of gender and sexuality. This delineation is also reflected in the judicial system's

\footnotetext{
4 Michel Foucault. History of Sexuality: An Introduction. trans. Robert Hurley. Vol. 1 (New York: Vintage Books, 1990)

5 Michel Foucault. History of Sexuality. 38

6 Michel Foucault. History of Sexuality. 69
} 
differentiation between pornographic and the erotic. Although the definitions of each have been legally challenged and revised over the years, the notion of community standards continues to be a decisive factor in distinguishing the erotic from the pornographic. In the contemporary period we are increasingly made aware that what is considered and affront in one community may not be in another. Although my argument cannot be reduced to a question of pornography versus eroticism, I want to underscore the relevance of community standards to my discussion.

Although I recognize that Foucault's analysis, does not represent the most recent theorization of sexuality and that it has been criticized as being "scrupulously ethnocentric"7 because of its failure to address issues of race and gender. His arguments are important because they continue to inform much contemporary theory and because his insights into the development of sexuality in early Western societies are relevant to the notions of sexuality, the body and gender brought to the Anishnaabe by Roman Catholic missionaries. As anthropologist Ann Laura Stoler, points out these notions were inextricably bound to the imperial project; ruling colonies "entailed colonizing bodies and minds. ${ }^{8}$ For Aboriginal people in North America the residential school was the one of the most important tools used to eradicate traditional Aboriginal beliefs and practices. Many Aboriginal children who attended residential schools were subjected to emotional, and physical

\footnotetext{
7 James Clifford quoted in Ann Laura Stoler. Race and the Education of Desire: Foucault's History and the Colonial Order of Things. Durharn: Duke University Press, 1995),14.

8 Stoler. Race and the Education of Desire, 4.
} 
abuse. Some including, Norval Morrisseau were also sexually abused. ${ }^{9}$ It is important to recognize that this traumatic experience maybe reflected in Morrisseau's treatment of erotic themes in his art. However the degree to which it has affected his choice of subject matter would require specialized psychological knowledge and is beyond the scope of this thesis.

Roland Barthes's discussion of mythology is also useful to my project. Barthes describes the process by which mythologies are transformed and how ideology becomes naturalized. In Mythologies, Barthes writes, "Myth hides nothing and flaunts nothing: it distorts: myth is neither a lie nor a confession: it is an inflexion. The principle function of myth is to transform history into nature." ${ }^{10}$ His theorization is very useful in explaining how ideologies of the middle class have been generated and reinforced through popular culture. His observations are particularly useful in demonstrating how the nude embodies and reinforces middle class values and ideologies regarding the body, sexuality and gender. Although Barthes's theories are based on his observations of post-war France, his insight into the role that mass media plays in propagating the values and beliefs of the middle class remains relevant.

Lynda Nead's theorizations are particularly helpful in examining the female nude within a western art history. Her book The Female Nude: Art, Obscenity and Sexuality provides a comprehensive examination of the meanings, and cultural

9 this disclosure was made by Morrisseau adopted son Gabor Vadas quoted in the film Norval Morrisseau: A Separate Reality. 2004 10 Roland Barthes. Mythologies. 1957. (London:Vintage, 1993), 129. 
assumptions that are transmitted by the depiction of the female nude within a patriarchical culture. Abigail Solomon-Godeau and Edward Lucie Smith on the other hand examine the connotations associated with the male nude. These scholars show how representations of the female and male nude, propagate the ideologies of the mainstream reinforcing prescriptive definitions of permitted and non-permitted pleasures, as well as gender and sexuality.

\section{Anishnaabe Theory}

In order to compare and contrast the ways in which Norval Morrisseau's depictions of the nude question the authority of mainstream meta-narratives, I have drawn on the work of both non-Anishnaabe scholars and Anishnaabe scholars. Anthropologists Irving Hallowell and Ruth Landes conducted fieldwork among the Anishnaabe people during the 1930's and 1940's. Their observations provide insight into the Anishnaabe worldview. It is ironic that their sojourns among the Anishnaabe communities of both Canada and the United States coincided with the enactment of some of the most aggressive assimilation policies of these governments, formulated as an attempt to eradicate the traditional belief systems of the people.

It is perhaps a testament to the resilience of the Anishnaabe people and culture that in 1965 Norval Morrisseau would publish the book Legends of My People: The Great Ojibway. This book is a collection of stories Morrisseau obtained from Anishnaabe community members and gives the reader a glimpse into 
Anishnaabe cosmology from an Anishnaabe perspective. This understanding has been supplemented with the writings of Anishnaabe scholar Basil Johnston and the more contemporary unpublished writings of Anishnaabe scholar D'Arcy Rheault. Although the research by anthropologists Will Roscoe and Sabine Lang are general studies of the fluidity of gender within Aboriginal cultures, ${ }^{11}$ their work acknowledges the presence and acceptance of this understanding within the Anishnaabe community, at least historically.

\section{Anishnaabe Cosmology}

The need to create order out of chaos is as fundamental to human beings as the act of breathing. It is necessary for our survival to create a sense of power and control over our destiny, to establish meaning in our lives. According to Hallowell all societies develop a worldview, it is the way in which the values and goals of a culture are affirmed. ${ }^{12}$ In this section I will discuss some of the basic tenets of the Anishnaabe worldview.

\section{The Division of the World}

The image of the divided circle best exemplifies the division of the Anishnaabe world. Donald Robinson notes that in Morrisseau's work "the divided circle represents all the dualities in the world, such as night day, good and evil. ${ }^{13}$ It is a world in which the sky world and the underworld exist together and maintain a

11 Aboriginal refers to status, non-status, Indian, Métis and Inuit.

12 A. Irving Hallowall. The Ojibwa of Berens River, Manitoba Ethnography into History. ed Jennifer H Brown (Toronto: Harcourt Brace College Publishers, 1992), 80.

13 Donald Robinson. "Tales of Copper Thunderbird." Norval Morrisseau Travels to the House of Invention (Toronto: Key Porter Books, 1997 ), 89. 
delicate balance. It is a world in which good and evil are seen as opposite sides of the same coin. Just as the thunderbird is considered to be a powerful being and a protector of the Anishnaabe, the thunderbird is also capable of destructive acts. This understanding is different from a western worldview, where this duality is rigidly divided. Divisions within the Anishnaabe world that do exist are differentiated in terms of animate and inanimate, unlike a western world view that divides the world into either masculine or feminine.

\section{Other-than- human-beings}

Hallowell termed the non-human persons who are believed by Anishnaabe to share the universe with humans as "other-than-human-beings. ${ }^{.14}$ In the creation myth those other-than-humans occupied the earth prior to the Anishnaabe. Consequently, they are referred to as the Grandfathers and Grandmothers. As Basil Johnston points out, those other-than-humans understand their place within the world instinctively whereas humans must learn their way. ${ }^{15}$ Anishnaabe scholar D'Arcy Rheault explains that human beings are considered as weak and must rely upon the kindness and assistance of those other-than-humans for their survival. Those-other-human-beings understood their purpose instinctively whereas humans had to learn how to acquire this information. As a result those other-than-humans or the animal beings as they are sometimes referred to, are considered to be superior to humans. As Rheault notes:

Humans are considered the weak being in the world. They need a great

14 this term recognizes that both communication and understanding is possible between human beings and those other-than-human-being . They share the same moral and values as Humans. For more information see Hallowell, The Ojibwa of Berens River. 80-99.

15 Basil Johnston. Ojibway Heritage. (Toronto: McClelland and Stewart,1976), 52. 
deal of help in finding the potential of their life paths, and even more help in learning to actualize it. They are not necessarily in tune with their intuitive abilities, and as such, struggle somewhat. It is taught that the clans came about due to the human being's fragility and with the animal world taking pity on them and adopting them to help them along. ${ }^{16}$

Rheault's statement underscores the importance of building and maintaining relationships between humans and other-than-humans-being. The personal guardian spirit however should not be confused with the do'dem (clan) animal or other-than-human-being, which according to Hallowell functions as a direct guide to interpersonal relations, and patterns of social behavior including sexual and marital relationships. ${ }^{17}$ Johnston reports that clans correspond to five functions of society; these are leadership, defense, sustenance, learning and medicine. ${ }^{18}$ According to D'Arcy Rheault there are six clans among the Anishnaabe: the Bear (medicine), Fish (philosophers and poets), Deer (mediators), the Bird (teachers and spiritual leaders), Loon and Crane (leadership). ${ }^{19}$

\section{The Vision Quest}

Fundamental to the Anishnaabe worldview is the belief that everyone is endowed with powers and gifts. Basil Johnston writes "every person is to seek a dream or vision with the expanse of his or her soul spirit being, and having attained it bring it, into fulfillment and reality." ${ }^{20}$ Through dreams and the vision quest one receives guidance through a guardian or animal spirit on how to obtain

\footnotetext{
16 D'Arcy Rheault, “Midèwiwin Organization of Knowledge.” (FC. 500 Unpublished paper Peterborough: Trent University. 1997 ), 14.

17 Hallowell. The Ojibway of Beren River, 50.

18 Johnston. Ojibway Heritage, 60.

19 Rheault. Midèwiwin Organization of Knowledge, 23.

20 Basil Johnston. The Manitous: The Spiritual World of the Ojibway. (New York: Harper Collins, 1995 ), 3.
} 
fulfillment. ${ }^{21}$ Anthropologist Irving Hallowell observed that among the Anishnaabe a human being was able to benefit both directly and indirectly from the superior knowledge and power possessed by those other than human beings. ${ }^{22}$ The vision quest is a rite of passage undertaken by young adolescent males, under the direction of an older male. It is believed that those other-than-humanbeings will see the young man, take pity upon him and come to his aid. This rite not only helps the adolescent identify his guide(s), but it establishes a relationship between the young adolescent and his spiritual guide that will continue throughout his life. As Armand Ruffo writes in his essay "Norval Morrisseau: Man Changing into Thunderbird," some of the beings are more powerful than others, "whoever dreams of such a snake will have the power to become a great shaman, to move through the four levels of the Midèwiwin, Grand medicine society. ${ }^{.23}$

\section{Shamanism}

As the excerpt from Ruffo's essay indicates, some Anishnaabe people through their dreams and vision quest establish strong ties with other-than-humanbeings and receive special powers and abilities that would separate them from others. These individuals are the Shamans. These powers are not bestowed upon the individual without expectations; the relationship is reciprocal, and, as

21 Johnston. Ojibway Heritage, 15

22 Hallowall. The Ojibwa of Berens River, 82.

23 Armond Ruffo. "Norval Morrisseau Man Changing into Thunderbird." Norval Morrisseau: Shaman Artist. Ed. Greg Hill. (Ortawa: National Gallery of Canada, 2006), 80 . 
Hallowell points out, obligations can take a variety of forms. ${ }^{24}$ Greg Hill observes one of the special abilities of the shaman is the capability to soul travel, consequently the Shaman sees the world very differently than those who do not possess such abilities. ${ }^{25}$ The ability to soul travel is possible because embodiment is seen as a temporary state. Humans and those-other-thanhuman are capable of metamorphosis.

\section{Transformation and Metamorphosis}

One of the most important tenets of the Anishnaabe worldview for the purposes of this thesis is the idea that the body is a temporary housing for the soul or essence of a being. Hallowell writes that the body is not a necessary condition for experience; the locus of personal identity and experience is the soul, which may be detached from the body. ${ }^{26}$ One's outward appearance can change and enable a metamorphosis to occur at will. But as Hallowell explains, this ability can only be acquired with the help and sanction of other-than-human-beings. To have this ability to change shape is a sign of someone who possesses a high order of power and indicates that this person shares in a very special relationship with other-than-human-beings. ${ }^{27}$ Anthropologist Sabine Lang feels that this contributes to the commonly held notion among many Aboriginal cultures that one's biological sex does not predetermine his or her gender. ${ }^{28}$

\footnotetext{
24 Hallowell. The Ojibwa of Berens River, 92.

25 Greg A.Hill. “Norval Morrisseau Shaman Artist” Norval Morrisseau Shaman Artist. (Ottawa: National Gallery of Canada, 2006), 27

26 Hallowell. The Ojibway of Berens River, 85.

27 A. Irving Hallowell. “Ojibwa Ontology, Behavior and Worldview.” in Irving Hallowell Contributions to Anthropology. Ed Stanley Diamond (Chicago

: University of Chicago Press, 1976), 377.

28 Sabine Lang. "Various kinds of Two-Spirited People: Gender Variance and Homosexuality in Native American Communities." in Two-Spirit People:
} 


\section{Literature Review}

There have been a number of books published about Morrisseau and his artwork, however very little attention was paid to his erotic work until the late 1990's. The choice of imagery that was made public though books reinforced the notion that Morrisseau was a tortured soul, controlled by his passions, and also reinscribed western notions of the body, gender and sexuality. ${ }^{29}$ In the book produced by Morrisseau's agent Jack Pollock and Lister Sinclair, The Art of Norval Morrisseau (1979), demonstrates this tendency. One image included in that publication included there. Artist in Union with Mother Earth (1975) depicts a male figure, which we assume is Morrisseau because of the title, engaged in a sexually intimate act with a female figure. (figure 1.1) As I will show, this manner of presenting the work buries its meaning.

In the mid 1980's there was a decisive shift in the way Norval Morrisseau's artwork was being discussed. Up until that time there had been numerous newspaper and magazine articles about Morrisseau that seemed to focus more on his personality than on a critical examination of this artwork. This change becomes visible with the exhibition Norval Morrisseau and the Emergence of the Image Makers that was co-curated by Elizabeth McLuhan and Tom Hill. ${ }^{30}$

Native American Gender Identity, Sexuality and Spirituality. Ed. Sue-Ellen Jacobs, Wesley Thomas and Sabine Lang. (Urbana: University of Illinois Press, 1997), 114

29 This same fate was shared by Morrisseau's contemporary Daphne Odjig as seen her collaboration with Herbert Schwarz that resulted in the publishing of a collection of erotic stories entitled Tales from the Smokehouse. The absence of sexualities that differ from the socially sanctioned; in effect silences these alternative understandings

30 McLuhan, Elizabeth and Tom Hill. Norval Morrisseau and Emergence of the Image Makers.(Toronto: Methuen, 1984) 
Elizabeth McLuhan's essay in the exhibition catalogue recognizes Morrisseau's contribution to contemporary Aboriginal art while acknowledging its roots. Her discussion chronicles the development of his style, while her analyses of the works utilize the lexicon of art history. In doing so she firmly establishes Morrisseau within the canon of Canadian contemporary art. Others would follow in the rigorous examination of Morrisseau's work established by McLuhan: Joanna Doherty's (1984) unpublished masters thesis is aptly titled $A n$ Examination of the Sources of Ojibway and non-Ojibway Elements in Norval Morrisseau's Art (1982). ${ }^{31}$ Curtis J. Collins' unpublished master's thesis entitled Janvier and Morrisseau:Transcending a Canadian Discourse $(1994)^{32}$ examines both Alex Janvier and Norval Morrisseau's oeuvre in terms of its ability to transcend the exclusivist definition of modern painting in Canada.

Art Historian Ruth Phillips has written several essays on Morrisseau. In her essay "Invoking Magic: Norval Morrisseau 's Art and Discursive Constructions of Art, Anthropology and the Postcolonial," Phillips traces a social history of Morrisseau's art work to illustrate how the academic domains of art history and anthropology overlap yet remain distinct. Her investigation also argues that Morrisseau's artwork is a postcolonial intervention that utilizes shifts and overlaps between these disciplines, and thereby inserts him into the canons of 
art history. ${ }^{33}$ In her essay “Morrisseau's Entrance: Negotiating Primitivism, Modernism and Anishnaabe Tradition," Phillips attributes Morrisseau's success to what she describes as a convergence between his desire for the recognition and respect of the Anishnaabe worldview and visual traditions and the aspirations of his patrons to insert Anishnaabe material culture into the art historical discourse..$^{34}$

Morrisseau's place within this canon has been affirmed by the National Gallery of Canada's exhibition Norval Morrisseau; Shaman Artist. It is the first time that an Aboriginal artist has been recognized by the premier Canadian art institution with a solo exhibition. Curator Greg Hill's essay "Norval Morrisseau: Shaman Artist." acknowledges that Morrisseau's indigenous background has not confined or defined Morrisseau's artistic expression. As Hill observes, Morrisseau has continued to open himself to opportunities to explore the worlds beyond his beginnings to gain new insights. ${ }^{35}$ This was not confined to his art practice but his personal life as well. These explorations along with his Anishnaabe beliefs regarding sexuality the body and gender have consistently found their way into his artistic expression.

\section{Methodology}

When I began this inquiry I had the good fortune of being a practicum student at

33 Ruth Phillips. "Invoking Magic; Norval Morrisseau Art and Discursive Constructions of Art, Anthropology and the Postcolonial." Anthropologie, objets, et esthetiques. Eds., Brigitte Derlon and Michele Coquet (Paris: Centre National de Recherche Scientifique, 2005). 34 Ruth Phillips. "Morrisseau's Entrance: Negotiating Primitivism, Modemism and Anishnaabe Tradition." Norval Morrisseau Shaman Artist. Ed. Greg Hill. ( Ottawa: National Gallery of Canada. 2006), 42-60. 
the National Gallery of Canada. My assignment was to assist curator Greg Hill by performing research and administrative duties. At the time he was in the preliminary planning stage of the National Gallery's exhibition Norval Morrisseau; Shaman Artist. One of my tasks as a practicum student was to determine how many images by Morrisseau were in public collections, I began with the Canadian Heritage Information Network, Artefacts site. It is limited in that not all of Canada's public institutions have their entire collections entered in the database, and often the information provided consists only of the title, medium, dimensions and accession number. I then approached the Department of Indian Affairs Indian Art Centre (INAC), the Canada Council Art Bank and the Canadian Museum of Civilization (CMC) in Hull. The latter two institutions were able to produce printouts that provided both a description of the works in their collection as well as a small image. When cataloguing images for the Hill, I noted any erotic images, photocopied or took digital images. Hill also took digital images of erotic work he came across while visiting public institutions that he thought would be of interest for this project. From the images collected, I selected the images discussed in this thesis based on whether or not the image critiqued western representations and western constructs regarding the body, sexuality and gender. Although I did not include private collections with the exception of Morrisseau's own, the Artefact database, INAC, CMC and other institutions I searched comprise the major public collections of Morrisseau's work.

In the fall on 2005 I was able to meet with Gabor and Michele Vadas and Norval

35 Hill. Norval Morrisseau Shaman Artist. 12-41 
Morrisseau in Nanaimo, British Columbia. Morrisseau, who has had a stroke and suffers from Parkinson's disease, finds it difficult to communicate. My intent was to interview Vadas about Morrisseau's erotic artwork. Instead of an interview I received permission to photograph the Vadas's private collection of erotic imagery. The public has never viewed this imagery and presently it is not available to the public, I was given permission to use the images for my research and educational purposes only. I also had the opportunity to interview Lee Ann Martin, one of the curators of the exhibition Exposed: the Aesthetics of Aboriginal Art for another project, but I have included some of her insights in this thesis.

As I mentioned, very little has been written about Morrisseau's erotic work until 1999. Two exhibitions, the Glenbow Museum's, The Art of Norval Morrisseau, the Writings of Basil Johnston and Lee Ann Martin and Morgan Wood's exhibition Exposed: Aesthetics of Aboriginal Art are very important in terms of this inquiry. Martin and Wood's exhibition was the major catalyst for this inquiry. This project is in a way a continuation of the dialogue Exposed began. Although the Glenbow's exhibition did not focus on the erotic, it did acknowledged an Anishnaabe worldview where understandings regarding the universe, the body and the relationship between other-than-human-being and humans differ from the western mainstream.

The Glenbow Museum's, The Art of Norval Morrisseau, the Writings of Basil Johnston juxtaposes the imagery of an Anishnaabe visual artist with the prose of 
an Anishnaabe writer. In doing so we see how these art forms not only complement but also inform each other. This is especially evident in the prose that appeared with Morrisseau's image Man and Woman (n.d)( figure1.2). The prose by Basil Johnston reads as follows:

\section{K'ZAUGI-IN}

\section{LOVE YOU}

\section{MYSOUL IS OPEN FOR YOU ${ }^{36}$}

Alone I was lost in the world of dream

I dreamed and I dreamed of you

I created you of dream

But with each dream

Left my dream and I was alone once more

Without a dream

But one evening

You emerged from the world of dream

And entered my world

A dream no longer dream

A dream become reality

Our hearts and spirits met

You took my hand in yours

And whispered "I love you"

To give me all your love and being

And invite me to enter your heart and soul

Hands locked in hand, hearts entwined

We set out upon the path of life

Our dreams now one

Our steps true and measured

Your love mine; mine yours

To help me know myself, the world.

You and Kitchi- Manitou

And to walk on into the world of dream

and beyond

36 Basil Johnston. "K'zaugi-in I Love You My Soul is Open For You." in The Art of Norval Morrisseau, The Writing of Basil Johnston. (Calgary:

Glenbow Museum,1999), 12. 
The prose is self-evident in that it speaks of love for another being. The ambiguity of the language prevents the reader from making the assumption that it is between two human beings or for that matter two beings of opposite sex. The image that accompanies this prose depicts the androgyny that posseses both human characteristics and those of the merman. ${ }^{37}$ The juxtaposition of this image with this particular text disrupts and critiques western constructs on many levels, in addition to a general recognition of a worldview that is unique and different from that of the mainstream. Although the theme of this exhibition was not an exploration of the erotic, it, along with the exhibition Exposed: the Aesthetics of Aboriginal Art, provided a framework and a methodology on which I have based my inquiry.

As curators Lee Ann Martin and Morgan Wood point out prior to their exhibition Exposed: the Aesthetics of Aboriginal Art, the absence of erotic expression was indicative of a reluctance, by those in positions of power in Canada's cultural institutions, to provide equal opportunities to express alternative understandings regarding sexuality and gender from those of the mainstream. ${ }^{38}$ Not only did their exhibition bring to the forefront and openly address this legacy of oppression, but it also addressed the effects of the Residential school experience in silencing indigenous perspectives. Many Aboriginal people have internalized Judeo-Christian beliefs and attitudes towards sexuality. Martin and Wood, being Aboriginal women, understood this legacy intimately and were careful not to

37 the merman is other- than- human- being that provide safe passage for Anishnaabe while traveling on water. From Norval Morrisseau. Legends of My People: The Great Ojibway. Hand written manuscript. (Calgary: Glenbow Museum archives),19. 
repeat the pattern of suppression. The exhibition explored the variance of sexual identities within the Aboriginal community and became a watershed that leads others such as myself to undertake an exploration of the erotic from an Aboriginal perspective.

In the wake of Exposed: the Aesthetics of Aboriginal Art came the publication of an important anthology of erotic stories entitled Without Reservation: Indigenous Erotic edited by Kateri Akiwenzie-Damm and published in 2003. Although the stories are largely contemporary, Akiwenzie-Damm presents them as a means to counteract stereotypes and misconceptions. Like this inquiry, my intent is to reclaim the erotic and give voice to what has almost become the unspeakable.

\section{The Chapters}

I begin each chapter with a story, not only to acknowledge the role the oral traditions play in inspiring Morrisseau's imagery, but also to establish that the erotic has a long history and to explore the role stories play within all Aboriginal cultures. As Basil Johnston has written, "the sole teaching aid of the Anishinauback was the story. For every event, belief, animal or Manitou, there was a story. ${ }^{39}$ These stories have ancient beginnings and speak of a world and understandings that existed before time. ${ }^{40}$ Indigenous knowledge is carried in them.

38 Lee Ann Martin. Personal communication. March 19, 2004.

39 Johnston. The Manitous, 171.

40 Although these stories are not Anishnaabe, two of the stories Old Coyote Man and Coyote Woman are from the Blackfoot nation and the are stories from the tribe groups that belong to the Algonkian language grouping. The language spoken by the Anishnaabe belongs to this family of languages. 
In Chapter 2, I discuss the female nude. I contend that even though Morrisseau's imagery seemingly reinscribes western notions about women, upon a closer examination of his imagery a very different understanding emerges. For example the depiction of woman as serpent within western art historical conventions implies a female sexuality that is out of control and uncontained. Within a patriarchical society this image of the autoerotic female is a menacing threat. I interpret Morrisseau's image of the Great Serpent Mother: Mother of all Serpents in terms of his metaphorical use of colour and his depiction of the female serpent in Anishnaabe oral traditions in order to show that women as serpents do not share in the sinister Biblical connotation of their western sisters.

In Chapter 3, I discuss the male nude. I argue that Morrisseau's depictions speak of masculinities that transcend the active/ passive binary found in the western historical construction of the male nude. This binary is composed of the hypervirile male and the feminized ephebic. Like the female nude in Western culture the binary embodies an ideology that defines sexuality in terms of a strict distinction of heterosexual and homosexual. Morrisseau's depiction of the male nude merges and blurs the boundaries, depicting the hyper-virile male as a nurturer. With his disproportionally large penis, Morrisseau's male nude flaunts his implied animality and sexual appetite.

In the final chapter the examination of Morrisseau's depictions of other genders 
helps reveals the constructed nature of sexuality and gender. The expression of gender in terms of sexual practice within the Anishnaabe culture was not prescriptive in the same way as western social constructs. It is well documented that in many Aboriginal cultures gender is not determined solely by one's biological sex. Morrisseau questions the exclusive terms in which one's gendered identity within western construction is conceived. His work also illustrates the belief found among Aboriginal cultures that non-reproductive sex is valuable for both its production of pleasure and emotional rewards, whereas other imagery discussed in this chapter reinforces and reaffirms the interrelationships been humans and those-other-than-humans. This imagery unmasks the differences between the worldview of the Anishnaabe people and that of the mainstream regarding sexuality.

Throughout my discussion I make use of binary oppositions that come from the Western worldview. Although such binaries can be seen as too rigid, I would also argue that the permeability of these opposed categories is often a function of one's social position, race, class and gender. In this thesis I look back over a course of a career that has spanned five decades during which attitudes towards sexuality, gender in Western societies have undergone profound changes. Although we live today in much more tolerant times, Morrisseau's concerns were formed in a much more repressive era. 


\section{Old Man Coyote Meets Coyote Woman ${ }^{41}$ \\ (Blackfoot)}

In the beginning there were only two human beings in this world-Old man

Coyote and Coyote Women. Old Man Coyote lived on one side of the world and Coyote Woman the other. By chance they met.

"How strange," said Old Man Coyote. "We are exactly alike."

"I don't know about that, "said Coyote Woman. "You are holding a bag. What's in it?" Old Man Coyote reached into his bag and brought out a penis. "This odd thing."

"It is indeed an odd thing," said Coyote Woman. "It looks funny. What it is for?" "I don't know, "said Old Man Coyote. "I don't know what to use it for. What do you have in your bag?"

Coyote Woman dug deep into her bag and came up with a vagina. "You see," she said

"We are not alike. We carry different things in our bags. Where should we put them?"

"I think we should put them in our navels," said Old Man Coyote" The navel seems to be a good place for them."

\footnotetext{
41 The Blackfoot are also known as the Siksikas. Their language belongs to the Algonquian family. This version of the story is from Richard Erdoes and Alfonso Ortiz. American Indian Trickster Tales. (New York: Penguin Books, 1999), 61-63. Another version of this story was collected during the years 1903-07 translated by D.C. Duvall and Clark Wissler. Their version appears in Mythology of the Black foot Indians. (Lincoln: University of Nebraska Press, 1995)
} 
"No I think not," said Coyote Woman, "I think we should stick them between our legs. Then they will be out of the way."

"Well alright" said Old Man Coyote. "Let's put them there." They placed these things between their legs.

"You know," said Coyote Woman. 'It seems to me that the strange thing you have there would fit this odd thing of mine."

"Well you might be right," said Old Man Coyote. 'Let's find out."

Coyote stuck his penis into Coyote Woman's vagina

"Um, that feels good," said Coyote Woman.

"You are right." Said Old Man Coyote. "It feels good, indeed. I have never felt this way before."

"Neither have I." Said Coyote Woman. "It occurred to me that this might be the way to make other human beings. It would be nice to have company. "It certainly would," said Old Man Coyote. "Just you and me could become boring."

"Well in case doing what we just did should result in bringing forth more human beings, what should they be like?" Said Coyote Woman.

"Well I think they should have eyes and mouth going up and down."

"No. no," said Coyote Woman. "Then they would not see well and food would dribble out of the lower corner of their mouths. Let's have their eyes and mouths go crosswise."

"I think that the men should order the women about," said Old Man Coyote, "and that women should obey them." 
"We'll see about that," said Coyote Woman. "I think that the women should pretend to obey, but in reality it should be the other around." "I can't agree to this," said Old man Coyote.

"Why quarrel?" said Coyote woman. "Let's just wait and see how it will work out." "Alright, let's wait and see. How should men live?"

"The men should hunt, kill buffalo and bears, and bring the meat to the women. They should protect the women at all times."

"Well, that could be dangerous for the men," said Old Man Coyote. "A buffalo bull or a bear could kill a man." Is it fair to put men in such danger? What should the women do in return?"

"Why, let the women do the work," said Coyote Woman. "Let them cook, fetch water and scrape and tan hides with buffalo brains. Let them do all these things while the men take a rest from hunting."

"Well, then we agree upon everything." Said Old Man Coyote. "Then it's settled.' "Yes, " said Coyote Women. "And why don't you stick that funny thing of yours between my legs again." 


\section{Chapter One: The Female Nude Form}

More than any other theme, the nude could demonstrate that art originates in and is sustained by male erotic energy. This is why many "seminal" works of the period are nudes. When an artist had some new or major artistic statement to make, when he wanted to authenticate to himself or others his identity as an artist, or when he wanted to get back to "basics" he turned to the nude. ${ }^{42}$

Carol Duncan

The Department of Indian Affairs wanted at one time to give me art lessons but, in my own opinion, this would have spoiled me, as nobody else could teach this kind of painting and perhaps I would have learned something else to corrupt my style.

Norval Morrisseau

Can a male artist from a different culture produce a different understanding of female sexuality through his depiction of the female form? If it is possible to produce a different understanding of female sexuality, what does that say with regard to the authority of a patriarchal sexual hierarchy and its myths regarding women's sexuality? In this chapter I explore these possibilities through the artwork of Norval Morrisseau.

The inspiration Morrisseau gained from the Anishnaabe legends he heard as a child and as an adult is clearly evident in his depiction of the nude or semi-nude

42 Carol Duncan quoted in Lynda Nead's Female Nude; Art, Obscenity and Sexuality (London: Routledge Press, 1992$), 45$.

43 Lister Sinclair and Jack Pollock. The Art of Norval Morrisseau. (Toronto: Methuen Publications, 1979), 22. 
female form, which was not restricted to the human form. ${ }^{44}$ As Overhalt and Calicott observe:

They mirror a series of complex interrelationships among a variety of kinds of persons: spirits and men, spirits and animals, spirit and spirits, men and men, men and animals, men and inanimate objects. ....also that animals are said to possess what we would normally consider to be human qualities: they can speak and plot complicated strategies and they have human emotions. ${ }^{45}$

Although their omission of women in this passage reflects the androcentricity of the 1980's, the authors observations do reveal the relation between animals and humans in the Anishnaabe worldview. These notions about the world are manifested in many of Morrisseau's depictions of the semi-nude or nude female form and provide a framework for examining Morrisseau's visual interpretations of Anishnaabe legends. The paintings I will discuss range from what western conventions consider to be allegorical representations, such as Mother Earth or Mother of All Serpents, to more direct representation of the human female nude. I have chosen these works because, as cultural historian Bram Dijkstra points out, since the 1900's the subject matter of Mother Earth and woman as serpent can best be described as evidence of a social paranoia regarding women which is a legacy that "still festers among us." 46

Morrisseau often revisited these subjects and themes, producing not just one painting, but several representations of Mother Earth and the Mother of All

\footnotetext{
44 See Morrisseau 's. Legends of My People. The Great Ojibway.

45 Thomas Overholt and J Baird Callicott. Clothed -In - Fur and Other Tales: An Introduction to a Ojibwa Worldview (Washington, D.C.: University Press of America,1982), 143.

46 Bram Dijkstra. Idols of Perversity: Fantasies of Feminine Evil in Fin-de-Sielcle Culture. (New York: Oxford University Press, 1986), ix.
} 
Serpents. My focus is not only on how his depictions differ from those of western artists but also what informs the differences among his versions. While Morrisseau may be producing images depicting the female nude, like western artists, a different understanding of the world and of women inspires his iconography.

The Great Serpent Mother: Mother of All the Serpents of the World. (1972) (see figure 2.1) is a two dimensional image of a woman in profile. Her hair is worn down and a portion of it fashioned into a small ponytail. Her lower torso is that of a serpent. Using heavy black form lines to define the outline of the female figure and to differentiate the inner world from the outer world, Morrisseau then subdivided the lower part of the figure with a red line forming "ovoid" filled with flat opaque yellow tone. These yellow ovoid shapes are treated graphically with what appears to be small black hatch marks. The figure appears to be kneeling or in a coiled position with the tail curving up and behind the figure. At the point where the tail curves behind the figure there is an ovoid shape subdivided by red lines and filled with a flat opaque green; this shape may be referring to the sacred meigis shell of the Midèwiwin medicine society. Ovoids are also used to depict an inner reality along with the eternal reality. On either side of the figure's tail is a smaller serpent. Here, Morrisseau uses the same method of the heavy form line and a red line to create ovoid shapes that are subdivided by green lines. The tails of the serpents are white and subdivided with small black lines, perhaps denoting that these are rattlesnakes. This same 
graphic treatment is used on the other two serpents in the image, one curves along the contour of the female figure's body with its' head parallel to the figure's breast while the other serpent appears to rest on her shoulder. Using a red line, each serpent is either connected to the female figure or to another serpent. From the beak -like mouth of the female figure a tongue protrudes. According to Mary B Southcott, the use of this design element indicates speech. ${ }^{48}$

In examining the imagery of The Great Serpent Mother and her offspring, the number of metaphors Morrisseau employs and his use of colour are striking. As I stated previously the use of colour as a metaphor has always been employed among the Anishnaabe. Morrisseau has always asserted that his use of colour is instinctive. In an interview in the 1970's with Art Magazine writer James Stephens, Morrisseau said that: "I do have a feeling for those colours. Each one has a meaning to me but I can not bring out that meaning to explain it." ${ }^{49}$ It is likely that the meanings Morrisseau associates with colours were influenced by the traditional teachings he learnt from his maternal Grandfather, who was a sixth generation Midèwiwin shaman. Among the Anishnaabe people colour is used as a metaphor for numerous concepts/beliefs within their cosmology. This is evident in the Midèwiwin origin tale recorded by anthropologist Ruth Landes from her informant, Hole in the Sky. He explains the symbolic representation of colour used in the Midèwiwin society as follows:

Our Grandfather [Bear] was black in colour at the Earth's bottom layer,

47 The term ovoid is used to describe an elliptical shape. The term was first coined by Bill Holm in his analysis of the art of the NorthWest Coast. 48 Mary E Southcott. The Sound of the Drum; The Sacred Art of the Anishnaabe. (Erin: The Boston Mills Press. 1984),43.

49 James Stephens. "Interview with Norval Morrisseau." (Art magazine. Vol. 5 no.18. 1974.), 29. 
representing woods and sticks lying there dead and bare. At the next layer he turned red, being surrounded by growing things-flowers and leaves. At the third level he was yellow, for the growing things had changed colour with the changing season. At the fourth level he was white, for snow. Also the colour represents the cardinal directions; east winds are black, south winds are red, west ones are yellow and north winds are white. We midè folk paint ourselves after them, for their pity.

The metaphoric use of colour is further substantiated. In the 1970's Edward Benton Banai, a respected member of the Midèwiwin society, published a series of children's books about the Midèwiwin teachings in The Mishomis Book. ${ }^{51}$ Throughout the narratives Benton Banai recounts the metaphorical associations illustrated by the four colours of the medicine wheel. As Anishnaabe scholar D'Arcy Rheault explains, the medicine wheel is a tool that assists a person in understanding the complexities of creation. ${ }^{52}$ (figure 2.2) Although Rheault states that there is no definitive medicine wheel, each of the four colours used is associated with: a direction, a medicine, a power, a human aspect and a sacred animal. ${ }^{53}$ Although colour symbolism is continually being reinterpreted what is evident is that colour is understood as being meaningful and an intricate part of the image's narrative. By using this medicine wheel as explained by Rheault to examine Morrisseau's use of colour, a multilayered narrative unfolds. ${ }^{54}$ In Morrisseau's image Serpent Mother, Mother of All Serpents he employs the primary colours; red, yellow, black and the secondary colour green. The colour red is associated the eastern cardinal point, its power is knowledge and

\footnotetext{
50 Ruth Landes. Ojibwa Religion and The Midèwiwin.(Ann Arbor: The University of Wisconsin Press.1968), 181.

51 Edward Benton Banai.. The Mishomis Book. (Saint Paul: Minnesota. Indian Country Press, INC. 1981)

52 Rheault. Midèwiwin Organization of Knowledge,8.

53 Rheault. Midèwiwin Organization of Knowledge, 8.

54 These were teachings the author received in 1981 in preparation for a ceremony.
} 
kindness. It is the direction that is associated with the element of fire. The colour yellow is linked with the southern cardinal point; the power associated with this direction is sharing and renewal, the human aspect is the body and the element is earth. Morrisseau's use of black for the form lines can be seen as a metaphor for truth and honesty as these powers are associated with the colour black and the western cardinal direction. Emotions are the human aspect associated with this direction and the element is water. The colour green is linked with Mother Earth and a downward direction. According to Rheault "it is here that one learns about their place in the world. ${ }^{.55}$

If we interpret this painting in terms of Morrisseau's use of colour, what we see is an image that is about kindness, knowledge, and sharing, all attributes that are considered to be human qualities. It is also an image about learning our place in the world as represented by the smaller serpent forms. The red lines that connect the figures to one another are illustrative of the interconnection between the mother figure and the offspring. Within the Anishnaabe worldview the serpent or snake is considered sacred. Morrisseau writes in The Legends of My People: the Great Ojibway that "the emblem in the Ojibway tribe was a horned snake, for any Ojibwa who dreamed of a horned snake or serpent he was considered to be a medicine man and to have knowledge of medicine. ${ }^{56}$ Anishnaabe scholar Basil Johnston writes that each animal has certain traits and symbolizes an ideal 
that is to be "sought, attained and perpetuated" by human beings. For example the trait to be embodied by the water snake is willingness, whereas the ideals symbolized by the rattlesnake are patience and slowness to anger. ${ }^{57}$

The female nude and the male artist have a long relationship within western art historical tradition. The belief that one's artistic talents or skills are directly related to one's ability to depict the nude is still very much part of the art education practices of institutions responsible for formerly training artists. Every art student at some point in his or her formal art training has found himself or herself in a life drawing class, standing in front of a blank paper and a nude model, while the professor expounds the virtues of the long historical tradition on which the student is about to embark. Today, the model may be a female or male subject, but throughout history this has not always been the case.

Nevertheless for art students the depiction of the nude is the test of their ability as artists in the western tradition, this is the proverbial yardstick. Because of this unspoken understanding the fear wells up in their belly. Although drawing the nude is considered as a rite of passage, art historian Lynda Nead points out, quoting Raymond Williams, "tradition has a duel meaning; it describes both a handing down of knowledge, or passing on of doctrine and a surrender or betrayal." ${ }^{\prime 58}$ Her observation reflects the ways in which a tradition such as the depiction of the female nudes' inclusion into western art education is not

57 Johnston. Ojibway Heritage, 53.

58 Nead. The Female Nude, 44. 
questioned and is continually reenacted without question.

As Lynda Nead observed in Female Nude: Art, Obscenity and Sexuality, "More than any other subject, the female nude connotes art...it is the icon of western culture, a symbol of civilization and accomplishment." ${ }^{59}$ Yet the depiction of the female form throughout western history has come under scrutiny for various reasons. It is not the intent of my discussion to offer a survey of the female nude, rather, it is to examine how a society's attitudes, beliefs and ultimately its worldview is revealed in the artist's depiction of the female form.

In the 20th Century the debate about depictions of the female form has ranged from differentiating between the nude and the naked, to examining and questioning the power and politics inherent in depictions of the female form within a patriarchical society. The latter signaled a departure from the neo-Kantian argument that works of art are not affected by political or social realities. Since the 1960's much of the discussion regarding the representation of the female form has examined how artistic practices and art institutions are "implicated in the production and reproduction of sexual positions in a way that manage desire and pleasure, fuel fantasies and situate the viewer." ${ }^{60}$

As Foucault pointed out, with the rise of the middle class, power was deployed

59 Nead. The Female Nude, 1.

60 Pollock, Griselda "Screening the Seventies." In The Feminism and Visual Cultural Reader. Ed by Amelia Jones.

(London: Routhedge Press, 2003), 81. 
through sexuality and occurred in a number of ways. What occurred in the western world was the establishment of a sexual hierarchy that "asserts the primacy of the masculine over the feminine, ${ }^{, 61}$ and the normalization of specific constructed definitions of gender and sexuality are of primary importance. As gender theorist Judith Butler points out in Gender Trouble: Feminism and the Subversion of Identity:

In the philosophic tradition that begins with Plato and continues through Descartes, Husserl and Sartre, the ontological distinction between soul (conscious, mind) and body invariably supports relations of political and psychic subordination and hierarchy... the cultural association of mind with masculinity and the body with femininity are well documented within the field of philosophy and feminism. Artistic production and the discourse surrounding it reveals this hierarchy and is especially evident in the female nude."62

By the late $19^{\text {th }}$ century, Nead reports that we begin to see a proliferation of the female nude, which she attributes to a shift in the definition of femininity and female sexuality. This shift she believes is related to the construction of an ideal of femininity based on economic dependence and passivity. ${ }^{63}$ Although Nead does not attribute this development solely to the rise of the bourgeoisie, she observes that it is the development of the deployment of power through the control of women's sexuality that is of interest at this juncture. What becomes evident is the way in which the female nude is called into service to demonstrate that form (the male) is preferred over matter (the female) ${ }^{64}$ This is very apparent in the art historical discourse and criticism of the 20th century. Nead cites art historian Kenneth Clark's The Nude: A Study in Ideal Form as an example of how

61 Nead. The Female Nude, 23.

62 Judith Butler. Gender Trouble: Feminism and the Subversion of Identity. (New York: Routhledge Press, 1999), 17.

63 Nead. The Female Nude, 48. 
discourse surrounding artistic production illustrates this point. I would also add that Clark's "examination" of the female nude is a reinscription of the triumph of culture (male) over nature (female) and ultimately the transcendence of mind over body under the guise of ascetic contemplation. This is underscored by Clark's description of the nude:

... the nude gains enduring value from the fact that it reconciles several contrary states. It takes interestingly the most sensual and immediately interesting object, the human body, and puts it out of reach of time and desire; it takes the most purely rational concept of which mankind is capable, mathematical order, and it takes the vague fears of the unknown and sweetens them by showing that the gods are like men maybe worshipped for their life giving beauty rather than their death-dealing powers. ${ }^{65}$

Although Clark is speaking about the nude in general, he encapsulates what the nude symbolizes in a patriarchical worldview - a worldview which divides the world into binary opposites: nature/culture, order / disorder, active/passive, rationality/irrationality, objectification/ subjectivity, and controlled /uncontrolled, to name a few. On so many levels, Clark's treatise on the nude substantiates art historian Laura Mulvey's assertion that within a patriarchal worldview "woman is never the maker of meaning, but the bearer of meaning." ${ }^{\text {66 }}$ It is a meaning that affirms that "woman" in the phallocentric worldview is defined in terms of negation.

Consequently, in the western artistic tradition, the metaphoric meaning of the snake and the female nude is much more sinister, compared to the Anishnaabe

64 Nead. The Female Nude, 23.

65 Kenneth Clark. The Nude: A Study in Ideal Form, (London, Murray.1956), 25.

66 Laura Mulvey "Visual Pleasure in Narrative Cinema" in The Feminism and Visual Cultural Reader. Ed. Amelia Jones. (London: Routledge Press. 2003), 43. 
worldview. For example the serpent who tempts Eve in Michangelo's Temptation and Fall (1510) is a semi-nude female figure with the lower torso of a snake wrapped around a tree, placing the forbidden fruit in the outstretched hand of Eve. (figure 2.3) The message is undoubtedly the role of women in the downfall of men, a sentiment that transcends time. In his discussion of the proliferation of misogynistic imagery during the fin-de-siècle, Dijkstra writes,

... the doings of Eve in paradise, and her being tempted by Satan, now became to be explained almost exclusively as a factor of her assumed general similarity, in terms of instincts and desire, to that most licentious primal length of living matter known to man, that seemly perpetually tumescent creeper which had kept man's loins from being the peaceful bower of spiritual bliss he dreamt it might be: the serpent. ${ }^{67}$

Indeed the association of woman with serpent has come to represent the autoerotic, the detached phallus, or the woman that does not conform to the patriarchical ideal of womanhood. But it also recalls a time when the prevailing belief was in an "organic cosmos with a living female earth."

The equating of woman and nature became symbolic of what man must control and overcome if he is to transcend and evolve. Within the construct of Cartesian dualism, women were associated with the body, emotion, the primitive and animality, and thus diametrically opposed to the association made between man and reason. Beginning with the scientific revolution, western society no longer saw itself as belonging to the natural world and began divorcing itself from any dependence on the biosphere. In doing so, "Western society denied women's

67 Dijkstra, Idols of Perversity, 305.

68 Carolyn Merchant. The Death of Nature: Women, Ecology and the Scientific Revolution. (San Francisco: Harper, 1980), xvi. 
activity and indeed the whole sphere of reproduction. ${ }^{69}$ Women and nature became what eco-philosopher Val Plumwood describes as the background to which all men's activity took place. ${ }^{70}$ This is particularly evident in the depiction of the female nude. Although women were often depicted as passive, the patriarchical society feared that women's civility was only a pretense. An apparent contradiction is embedded in the identification of land and women as virginal yet a voracious succubus. The female nude embodies western man's fears and anxieties while the passive female nude becomes a projection of the phallocentric desire to control and contain women's sexuality. As a result within the western artistic tradition the female nude is depicted as submissive and passive, or she is depicted in such a way that she embodies patriarch's fear of female power.

In contrast, Morrisseau's depiction of the earth as feminine illustrates some very different notions regarding the association of earth, women and the feminine demonstrated in his painting Mother Earth (1975)(figure 2.4). ${ }^{71}$ In this acrylic on canvas painting from a private collection, a depiction of a female form is shown in Morrisseau's characteristic combination of frontal view with a side facial profile. On a background of brilliant red his black arabesque form lines separate the elements from each other while also indicating the interconnection among them. The predominate element is the image of a nude female form as indicated by her bare breasts and stylized depiction of female genitalia. She appears to be sitting

69 Val Plumwood. Feminism and the Mastery of Nature.(London:Routledge,1993), 21

70 Plumwood. Feminism and the Mastery of Nature, 21. 
cross-legged, which exposes her genitals, depicted as a red circle with small yellow dots. The circle is then divided by two black elongated lines perpendicular to each other to depict the vulva. The space between the two black lines depicting the labia minor is yellow, while her breasts are yellow and sienna red like the rest of her body. Her arms cross in front of her body, while her right hand seems to be in the process of transforming into a bird. On her wrist and upper arms she wears what appear to be arm and wristbands painted in dark green that almost appears black. Around her neck she wears medicine bags in colours of blue, black and dark green. The figure's long black hair is worn loosely, falling over her right shoulder with ear locks on either side of her face. These ear locks appear to be wrapped or bound by coloured bands at the upper and lower portions. On her head she wears an ornate headdress constructed of ovoid shapes filled with flat opaque colours of red, green, blue, yellow and purple. In the upper left corner is a yellow circle outlined with a black form line and black lines radiating outward. Two of these black-radiating lines connect to two human heads, both of which are shown in profile. One head is depicted with an elongated body painted blue with black forming lines creating a graphic design depicting what appear to be ribs. He / she is devoid of any limbs and faces the female form. Both this human figure and the female form with their beak like mouths appear to be conversing. On the back of the human figure are two heads, one positioned above the other, facing outward and away from the central imagery. This seemingly odd combination of human heads and a limbless body appears to be resting or supported by the head of a bear. Below the bear

71 Sinclear and Pollock. The Art of Norval Morrisseau. 125 
Morrisseau once again employs a circle motif, its contour defined by a black form line and filled with a flat opaque medium blue colour. Similar to the other circle, three black lines emanate from the circular form joining the bear to a fish upon which the female form appears to be sitting. The graphic design of the fish illustrates what Mary Beth Southcott has described as cloisonnism ${ }^{72}$ of deep reds, purple, greens and blues. Above the fish's tail fin and nestled beside the left leg of the mother earth figure is a bird that resembles a loon, which also demonstrates Morrisseau's use of cloisonné-like graphic treatment.

This image of Mother Earth, humans, and other-than-human-beings illustrates Anishnaabe notions of the connection between the earth and women and also of the interconnections marking relationships between the humans and the otherthan-human-beings. The imagery of the bear, fish and loon carry with them a plethora of references within Anishnaabe oral tradition which tells us of a time when the humans first came to live on this earth. Not knowing how to survive they looked to those they considered as their older brothers and sisters, known as those other-than-human-beings, to teach them what they needed to know to live and thrive. In Ojibway Heritage, Basil Johnston writes that "man was dependent upon the animals for his food, clothing and tools; man was also dependent upon animals for knowledge of the world, life and himself." ${ }^{73}$ This is how the formations of clans or kinship nindoodemag ${ }^{74}$ came into being, which is differentiated from an individual's personal spiritual guide that also takes the form

72 Southcott. The Sound of the Drum, 46.

73 Johnston. Objiway Heritage, 52. 
of an animal. The nindoodemag are equated with the basic social units needed to function as a community, and Johnston outlines these as leadership, defense, substance, learning and healers. ${ }^{75}$ Membership in a kinship clan was patrilineal; Morrisseau's maternal grandfather's do'dem was the bear and Morrisseau's own do'dem is the loon. In an interview, Morrisseau stated that he adopted the bear as his do'dem out of respect for his grandfather and this was also his own personal guardian or protector. ${ }^{76}$ The bear is a very important figure in the Anishnaabe worldview, for it is told that Bear brought the Midèwiwin ceremony and teachings to the Anishnaabe people. In an interview with gallery owner Donald Robinson, Morrisseau relates to him that while on his vision quest as a young boy, it was a bear that came to him. ${ }^{77}$

In Mother Earth, I believe that the presence of the loon, fish and bear can be interpreted as being representational of nindoodemag. Rheault states that the loon clan represents responsibility and leadership, the fish clan signifies philosophers, poets and the intellectuals, and the bear clan is associated with medicine people and healers, representing protectors and keepers of vision. ${ }^{78} \quad$ । believe that it is possible to see the presence of these animal totems along with the depiction of human beings as being representative of the sky world, the earth world and underworld. This interpretation would underscore the interconnection and interdependence between these worlds. The notion that humans are the

\footnotetext{
74 The singular form of nindoodemag is do'dem

75 Johnston. Ojibway Heritage, 60.

76 Norval Morrisseau Artist File. National Gallery of Canada
} 
most dependent is manifested in this image by the absence of limbs on the human forms. This is augmented by lack of hair, which can be seen as symbolic of infancy and a time of life in which we are very dependent upon others to help meet our physical needs.

The symbol of the sun, referred to as Father sun, signifies the cyclical and linear nature of time; the pathway of the sun marks the passage of time. Basil Johnston informs us that this comparison of man-father goes beyond the apparent and the physical, to signify the relationship of the sun in its role in the reproductive cycle of planets and animals, which human beings rely on for substance. ${ }^{79}$ Morrisseau employs the circle motif in two other instances and both can be viewed as referring to woman or female. In his depiction of the fertility of Mother Earth, the female figure's genitals are accentuated by his use of colour and graphic design. The colours used can be interpreted in terms of the medicine wheel, as explained previously. Red is associated with knowledge and kindness while the colour yellow is linked with sharing and renewal. The sacredness of the earth's fertility is further demonstrated by the employment of what Southcott has termed sacred dots, which she believes to be associated with the sacred megis shell. ${ }^{80}$ Morrisseau's graphic treatment of the female genitalia in Mother Earth is consistent with a number of his erotic images. He uses the circle as a symbol to develop the narrative interconnections of his images.

77 Donald C. Robinson. Norval Morrisseau Honoring First Nations. (Toronto: Kinsman Robinson Gallery), 7.

78 Rheault. Midèwiwin Organization of Knowledge, 23.

79 Johnston. Ojibway Heritage, 23.

80 Southcott. Sound of the Drum, 38. 
Subtle differences in the graphic treatments distinguish one interpretation from another, as illustrated by the second circle in Mother Earth that is filled with an opaque blue colour. Southcott's discussion of the significance of Anishnaabe iconography presents the circle as symbolizing perfection, completeness and continuity. It also represents woman or female. ${ }^{81}$ This graphic treatment of the circle differs from the divided circle, which is employed to symbolize Morrisseau's view of the world as a series of balanced dualities— good and evil, day and night, heaven and earth etc. ${ }^{82}$ These are not seen as separate entities of being, "either or," but rather, as a recognition that good and evil exists with everything.

In this painting of Mother Earth the image of the nude female form is thus depicted with the same degree of reverence and sacredness that Morrisseau affords to a number of other images of women such as his Virgin Mary with Christ Child and St John the Baptist (1973)( figure. 2.5) and the image Artist's Wife with Daughter (1975)( figure 2.6). Both of these paintings also allude pictorially to an association of the sacred with mothers and the act of creation. This association is also found in the Ojibway language. In Jordan Paper's discussion of feminine spirituality in Native American religions, he observes that the word for Earth - aki and the word for vagina, akitun share the same root: aki. The addition of the suffix tun specifies movement. Consequently, the Earth is translated literally as a still vagina or conversely the female vagina is translated

81 Southcott. Sound of the Drum, 40.

82 Sinclair and Pollock. The Art of Norval Morrisseau, 56. 
as an active earth. ${ }^{83}$ From this we can infer that the feminine as illustrated in Morrisseau's depiction of Mother Earth does not reinforce the western notion of the earth, or woman as the passive background against which all men's activity takes place. Rather, Morrisseau's depiction of the female form speaks of an active sexuality which is profoundly creative and gives us a glimpse of woman as an autonomous sexual being who is both a subject and an object of desire.

It is the active sexual aspect of woman that is the subject of Morrisseau's painting entitled Woman (circa 1960) (See figure 2.7). Painted in acrylics, this two- dimensional image is an example of Morrisseau's more economical use of line and detail. On a coloured background of blocks of dark and light green, a nude woman is depicted in a stylized replication of a classical reclining nude pose. The female form is portrayed using a combination of a side profile with partial frontal view of her body. Her lower limbs disappear out of the frame and off the canvas. Around her neck she appears to be wearing a necklace or medicine pouch. Although the figure's long hair is loosely piled on her head and secured with a red band, thick strands of hair cascade over her shoulders and are held in place by blue ties. On her face is a series of black dots-one above the other, following the outline of her cheekbone and tracing a line down toward her mouth to her chin, perhaps depicting a facial tattoo? Her arms reach underneath her knees while her hands grip her thighs as she holds open her legs to reveal her genitals. Pubic hair seems to radiate from her genitals and, as in

83 Jordon Paper. "Through the Earth Darkly: The Female Sprit in Native American Religions." Religion In Native North America. Ed by Christopher Vecesey (Moscow, Idaho: University of Idaho Press, 1990), 14. 
Morrisseau's other erotic images, there are sacred dots painted on the genital area. The negative space created by thick black lines, which form her torso, against the background, is painted orange instead of green, perhaps alluding to a heightened state of arousal. Resting on the figure's thigh and arm are two birds outlined in thick black form lines and filled with an opaque blue colour. Within these blue forms, thin form lines curve to create a spiral representing an x-ray image of the birds' interior. The presence of these birds at first seems out of place. However, the eyes of the birds are composed of a circle within a circle indicating that the birds are otherworldly. ${ }^{84}$ They also create a focal point, countering Morrisseau's positioning of the female form and her averted gaze, which create a directional line that leads the eye away from the image. This directional line produces a feeling that there is more occurring beyond the spectator's vision, outside the picture frame. This creates a tension that cannot be resolved; the spectator becomes aware that he/she can only be a spectator. In John Berger's sense, Morrisseau's Woman typifies the naked in that we as spectator can only witness the relationship as she presents herself and desire for her lover. Woman is an expression of the figure's sexuality, not the spectator's; she is different from the nude because it is her will and intentions that are revealed. ${ }^{85}$ It is perhaps for this reason that Peter Goodard described this image as a "lusty naked woman." ${ }^{86}$ It is not clear if he is referring to her lustiness as description of her physical condition or robust state of health or in terms of her

84 Southcott. The Sound of the Drum, 41.

85 John Berger. The Art of Seeing. (London: BBC/Pelican, 1972), 54.

86 Peter Goddard as quoted in Norval Morrisseau and the Development of the Woodlands School of Art 1960-1980. (Toronto: Maslak McCleod Gallery ),15. 
apparent state of arousal.

Although Berger states that the naked is free of patriarchal conventions, his statement is somewhat problematic when applied to Morrisseau's Woman, as this image makes what is considered private within a western worldview into something very public. As Lynda Nead points out, it is the space in which an image is viewed that differentiates between the erotic and pornographic. ${ }^{87}$ The distinctions between public and private are not as stringent or strictly policed within the Anishnaabe community as they are in cultures influenced by western Judeo-Christian ideologies and beliefs. Although Landes's observations regarding the Anishnaabe written during the 1930's are laced with judgmental rhetoric, as seen in her written description of Anishnaabe attitudes regarding sex, her statement reveals the community's attitude of the period.

Promiscuous love practiced between boys and girls exists not only because of the absence of adult supervision, but also because of the general attitude in the community regarding love and sex. These are considered very enjoyable, socially and sensuously. ${ }^{88}$

Many of the culture-hero myths contain a number of examples of this attitude of the community towards sex and love. While these stories are often told by men, Landes points out that: " Through the winter months older women often tell their life histories and devote a great amount of time and interest to elaborating their past affairs with lovers and husbands." ${ }^{.89}$

87 Nead. The Female Nude, 100.

88 Ruth Landes. The Ojibway Woman (New York: Columbia University Press, 1938), 42.

89 Landes. The Ojibway Woman, 42. 
Morrisseau brings this understanding to our attention in his painting Woman. Even if mainstream ideas regarding female sexuality have become ingrained, and what it means to be female is now defined in terms of a patriarchical social construct, Woman reminds us that this has not always been the Anishnaabe reality. Her tattoo marks her as speaking from a different time, a time that, ironically, feminists envision for the future where " beyond her maternal roles, the mother is also a woman, a subject, with a life, sex and desires of her own." ${ }^{90}$

Morrisseau's depictions of the female nude in its various incarnations appear to replicate the dominant patriarchical representations of woman, but when the imagery is examined in terms of an Anishnaabe worldview a different mythology and construct is revealed. Morrisseau bases much of his imagery on the legends and stories of the Anishnaabe people, stories meant not just to entertain but also to instruct the Anishnaabe on how to live. The stories are the Anishnaabe's truth, a truth that encompasses a cosmos where sexuality and desire are only one aspect of a being. Morrisseau's images are like mnemonic devices that remind the Anishnaabe of a different way of knowing. They enable us to begin to unravel and question the authority of patriarchical assumptions and the social construct of woman. 


\section{How Trickster Loses His Penis ${ }^{91}$}

As Trickster was walking along, he came to a particularly scenic land. Since he was getting sleepy, he decided to lay down and take a nap, so he laid under his blanket and went to sleep. After a while, he woke up and as he looked up he could see something floating above him.

He thought to himself, "Ah, yes! It is the chief's banner -- they always do thus when they are about to give a feast." Then he noticed that his blanket was missing and he suddenly realized that it was the blanket that was floating above him. It was high in the air because Trickster had had an erection during his sleep. He said to himself, "Thus it always is with me." Then he addressed his penis, "Younger brother, bring the blanket back before you lose it." Trickster took his penis in hand, and as it got softer, the blanket finally floated down. He took out the box in which he kept his penis and began to coil his member up and pack it away. Only when he had reached the tip did he finally retrieve his blanket. Trickster carried this box on his back.

Trickster once again set out on his travels. As he wandered aimlessly, he descended a slope until he came to a lake. On the opposite shore a group of pretty young women, a yûgiwi ${ }^{92}$ and her friends, were skinny dipping in the lake.

91 http:/www.hotcakencyclopedia.com/ho.Tricksters Penis.html accessed 4.01..2006. This story is not an Anishnaabe story but it is told among the Hocâk people also known as Winnebago. The Winnebego tribal lands are wedged between Algonquian speaking tribal groups. 92 Yûgiwi is Hocâk for princess. 
"Ah yes," Trickster said to himself, "my chance has come -- now I will get some sex." He took his member out of its box and gave it clear instructions: "My younger brother, you are to go straight for the yugigiwi and pass by the other women. Lodge right in her and no one else." Then he dropped it in the water, but it slid across the surface of the water, so Trickster called to it, "Little brother, come back! If you come up to them like that, you will scare them off." Trickster pulled his penis back and tied a stone around its neck and launched it again, but this time it dropped to the bottom of the lake, so he had to reel it back in again. Once again he tried, this time by tying a lighter stone to it, but the penis was too close to the surface and created a wake as it moved. "Come back, little brother, come back," Trickster shouted. Once he had reeled it in, he attached a stone of just the right weight, and sent it on its way again. This time his penis went right for the mark, but on its way it just barely grazed the other women. They yelled to the yûgiwi, "Get out of the water! Get out of the water, quick!" but the yûgiwi was just too slow to move and the penis lodged right in her just where Trickster wanted it. As the princess came out of the water, the penis was lodged right in her, and the other woman tugged hard to get it out, but could not dislodge it. The young women, who had no idea what had attacked their friend, ran to the village and returned with the strongest men they could find. These tried very hard to pull it out, but they could do nothing. However, one of the men said, "An old woman lives near here and she has knowledge of many things. Perhaps she can do something." So they ran off to get her. When she arrived, she immediately knew what was going on and told them, "This is Kunu, ${ }^{93}$ the one that they call

93 Kunu is Hocâk for Trickster 
'Trickster.' He is having sex with her, and all we are doing is intruding." She left, but came back soon after with an awl. She straddled the penis and pushed the awl in and out several times while she sang,

Kunu, if it is you; Pull it out, pull it out.

Then, unexpectedly, the penis jumped out with such force that the woman was thrown through the air. The woman was in a state of shock, but managed to get to her feet. As she stood there, Trickster laughed from the opposite bank and shouted, "You nasty old woman, why have you spoiled my fun? I was trying to have sex, but now the moment is ruined!" 


\section{Chapter Two: The Male Nude Form}

Biological sex, in this sense, is thus fundamentally distinguished from gender, which is conceived as a contingent, variable, and inescapably social ensemble of values, beliefs and behaviors projected and imposed upon the physical givens of sexual difference. ${ }^{94}$

Abigail Solomon-Godeau

In the painting we see the love of the male body. It is a sensuously beautiful body, encircled by serpents, Freudian symbols of sex. The heads of two serpents hiss before the man's face, and from the face of the man we read that it will be a long patient struggle. It is a face of acceptance, of humility - Despair has not conquered. ${ }^{95}$

Ann Daniel.

Depictions of the male nude have a history dating back to antiquity, even though whenever we think of the "nude" we have a propensity to equate this term solely with the female form. This is probably due to the proliferation of paintings of female nudes during the last 300 years. However, we have a tendency to forget that depicting the female nude was an anomaly prior to the rise of the middle class. As Lynda Nead points out "in very general terms, it can be said that the unclothed male model dominated the life class in European academics and studios up until the late eighteenth century." ${ }^{.96}$ It can be argued that the male nude unlike the female nude did not become an object of erotic contemplation until recently, when its value as a commodity within a consumer culture grew. Still, within patriarchal societies and even in a contemporary context the

94 Abigail Solomon-Godeau. Male Trouble: A Crisis in Representation. (London: Thames and Hudson. 1997), 19.

95 Ann Daniel. "Norval Morrisseau: Myth and Reality." The Challenge. (Montreal) 11, Dec 1966. National Gallery of Canada Artist File. 
objectified male body still signifies dangerous territory. On one level the male nude alludes to a recognition of the possibility of a female gaze, but according to Kenneth Mackinnon, the greater threat of the male nude is in "it's revelation of the homoerotic potential surrounding the viewing of male objects." ${ }^{.97}$

Historically, in the western art tradition the male nude, unlike the female nude, was always "embedded in narrative, myth or allegory," ${ }^{98}$ thus allowing it to transcend and disavow the erotic. Concurrently, culturally sanctioned representations of ideal manhood expressed by the male nude evolved into two social constructions which art historian Abigail Solomon-Godeau describes as "a heroic, virile and purposeful manhood understood as active and dominating, and a typically younger model - adolescent or ephebic, whose sensual and erotic appeal derives at least in part from its relative passivity." ${ }^{99}$ Art historian Edward Lucie Smith divides the feminized youth into sub-types that he terms as the "antimasculine male." This male nude is represented as the naked child, the pubescent youth, and the androgynous being. ${ }^{100}$ These sub-types activate discussions on a number of levels regarding male sexuality and its articulation in western society. First, they point to a western ideology that reduces sexuality to the dichotomous categories of heterosexuality or homosexuality. Second, these sub-types activate recognition of the male body as an object of erotic contemplation.

96 Nead. The Female Nude, 47.

97 Kenneth Mackinnon. Uneasy Pleasure: The Male as Erotic Object. (London: Cygnus Arts of Golden Cockerel Press. 1997$), 22$.

98 Solomon-Godeau. Male Trouble, 26.

99 Solomon-Godeau. Male Trouble, 26. 
Although the association of the male nude with the heroic and allegorical has historically allowed the male nude to elude erotic objectification, this is no longer always the case. In view of the feminist, gay and lesbian movements, new perspectives have been formulated regarding the male nude which reveal not only the instability of the binary construct of masculine and feminine, but of their dominance as well. Consequently, this has led to a reexamination of homo / heterosexual classifications of all sexuality. However, it is still questionable as to how far we have moved away from these social constructs, especially considering the cover photos found on men's health magazines and the flourishing of the metro-sexual male. Most important for the purposes of my discussion is the examination of how Norval Morrisseau's depiction of the male nude refuses to comply with the western social construct of masculinity as embodied in the representations mentioned above. I contend that because his depiction of the male nude often merges and blurs the boundaries between these archetypes, Morrisseau participates in what art historian Eve Kosofsky Sedgwick describes as an "endemic crisis of homo/heterosexual definitions."101

In contrast to the western worldview, the Anishnaabe traditionally have seen gender as being fluid and not fixed or determined by one's biological sex. Like many First Nations cultures there are words in their languages that describe this understanding. In the Anishnaabe language, for

100 Edward Lucie-Smith. Adam: The Male Figure in Art. (New York: Rizzoli.1998), 58.

101 Eve Kosofsky Sedgwick. Epistemology of the Closet. (Berkeley: University of Califomia Press, 1990), 1. 
example, the term agokwa is used to describe a biological male who performs gender roles of a woman. Conversely, the term for a biological woman, who performs the gender roles of a man, is okitcitakwe. ${ }^{102}$ Many early explorers and ethnographers were aware of these gender variances. This fluidity is noted by Peter Grant in his "The Sauteux Indians ${ }^{103}$ About 1804." published under the title of Les Bourgeois de la Compagnie du Nord-Quest. He writes:

I have known several instances of some men who by virtue of some extraordinary dream, had been affected to such a degree as to abandon every custom characteristic of their sex and adopt the dress and manners of a woman. They are never ridiculed or despised by the men on account of their new customs, but on the contrary respected as saints or beings the same degree inspired by the Manitou. . ${ }^{104}$

Will Roscoe's chart entitled Tribal Index of Alternative Gender Roles and

Sexuality indicates that the ethnographer Irving Hallowell observed alternative gender roles for both males and females among the Ojiway people in the 1930's and 40's. ${ }^{105}$ As well, anthropologist, Ruth Landes observed similar variances in gender roles for women during the same period and writes of these in her books. ${ }^{106}$ Although within a contemporary context these variances may seem normative, one must consider the time in which these observations of gender variation were written and the lack of comparative gender roles that were culturally sanctioned in western society at that time. One can say that that contemporary western society

\footnotetext{
102 Will Roscoe. The Changing Ones: Third and Fourth Genders in Native North America. (New York: St. Martin's Press, 1998 ), 237. 103 the Saulteaux are a branch of Ojibwa and are sometime referred to as the Plains Ojibway 104 Peter Grant “The Sauteux Indians About 1804." Les Bourgeois de la Compagnie du Nord-Quest Recits de Voyages, letters et rapports inedits relatifs au nord-ouest canadien. Vol..2, ed. L.R. Masson, (New York: Antiquarian Press, 1960.), 357. 105 Roscoe. The Changing Ones, 237.
} 
is only beginning to understand what many Aboriginal societies have known since time immemorial. Unlike the ethnographers of the past, who viewed these variations as pathological maladjustments, many Aboriginal societies including the Anishnaabe accommodated these variants. Morrisseau's depictions of the male nude are a testament to this understanding.

As I have noted, the male nude has a long but closeted history in terms of its recognition as an object of erotic contemplation. The arts of the Greeks and Romans attest to the eroticism of the male nude in ancient times. In fact one might venture to say that it is the only time in Western history when the male nude was openly appreciated for its eroticism. ${ }^{107}$ The influence of Fifth Century Greece is largely present in western art, as evidenced, by the established depictions of the male nude that continue to be replicated throughout history. Although Morrisseau's imagery is derived from Anishnaabe oral traditions, one gets the sense that there is a reinscription or at least recognition by Morrisseau of these archetypes. Morrisseau's images of the male nude exemplify his understanding of a "special language for the male penis," and his assertion that "it is the most sacred object in the spirit world." ${ }^{108}$ Yet, Morrisseau's depictions always take the viewer beyond the obvious pictorial representation to layers of deeper meaning. The images I will discuss illustrate Morrisseau's use of the archetypes established by western art historical conventions, as described by art

106 Ruth Landes. See her books entitled Ojiway Sociology and Ojiway Women for more information on this.

107 for more information see Andrew Stewart's Art, Desire, and the Body in Ancient Greece. 
historians Solomon-Godeau and Lucie Smith, along with the original insight drawn from basic tenets of the Anishnaabe worldview. This is particularly evident in his images of Shamans, and mythical beings in his self-portraits. These images recall the virile active heroic nude, a theme Morrisseau has revisited numerous times throughout his career such as seen in Self Portrait of an Indian Artist (1985) as well as a number of untitled images from the private collection of Michele and Gabor Vadas (Morrisseau's adopted son). (see figure 3.1). Unlike the western heroic male whose maturity is characterized by exaggerated masculine characteristics that emphasize the perfect male physique, Morrisseau focuses our attention on only one part of the male physique, the penis, featured in the erotic images he has created throughout his career. Morrisseau is consistent in depicting the male nude with a disproportionally large penis.

In comparison a long-standing protocol has governed the modest depiction of the classical western male penis. This disparity has been noted among western art historians, and they have offered several explanations for the historically diminutive size of the classical nude's penis. Solomon-Godeau states that its modest size is the result of a convention established in the fifth century BC. ${ }^{109}$ For Edward Lucie Smith this seems to indicate that the Greeks were not at ease with male nudity as originally thought and that the undersized penis was an indication of a wariness about giving full expression to the idea of male sexual

108 Lee Ann Martin. Exposed the Aesthetics of Aboriginal Erotic Art. Exhibition catalogue. (Regina: McKenzie Art Gallery, 1999 ), 43. 109 Solomon-Godeau. Male Trouble, 90. 
potency." ${ }^{110}$ However, as Solomon-Godeau points out, it is more probable that the representation of the male sex was a reflection of the tastes, beliefs and sexual practices of the period. In particular, for the Greeks, the socially sanctioned subject of desire for a man was not another man but an adolescent boy. According to art historian Eva Keuls, this was not limited to eroticism or aesthetics, but was a given a biological rationale. She notes that Aristotle theorized that the small penis was more fertile. ${ }^{111}$

On the other hand the Satyr (see figure 3.2)— the mythical half man and half beast was portrayed in a radically different manner in that his genitals are always depicted in extreme proportions as compared to the classical nude. SolomomGodeau, states that this was not testament to the Satyr's masculinity, but rather to his animality. ${ }^{112}$ The Satyr is thus the antithesis of the classical male nude whose animality and sexual appetite is sublimated and controlled. The mythical being was associated with instinct, and his large genitalia were an indication of his lack of civility. The remnants of this concept are still with us to this day and are indicated in the sexualized construction of cultural "Others". Researcher Irvin Schick points out that constructing the "Other" as sexually different-as possessing unrestrained, and uninhibited sexuality — results in both a fear of and fascination with the "Other." ${ }^{113}$ Whether or not Morrisseau was capitalizing on this "othering" to appeal to a non-Aboriginal audience is difficult to ascertain.

110 Lucie Smith. Adam: The Male Figure in Art, 21.

111 due to the distance the seed had to travel; a shorter distance meant that the seed would have less time to cool 112 Solomon-Godeau. Male Trouble, 182.

113 Irvin Schick. The Erotic Margin The Erotic Margin: Sexuality and Spatiality in Altertist Discourse.( London: Verso.1999), 168. 
However, one cannot ignore Anishnaabe conventions established in the pre contact tradition for depiction of shamans in petroglyph rock art, as illustrated in Phallic Figure (see figure 3.3) found at the Peterborough petroglyph site in Ontario. Morrisseau would have been exposed to this ancient art form by both his grandfather and friend and mentor Selywn Dewdney. Through his early mentors Esther and Joseph Weinstein and their extensive library, to which Morrisseau had access, he undoubtedly would have been aware to the arts of other non-western cultures, namely African art, where depictions of the phallus, like the vulva, were commonplace in fertility objects. ${ }^{114}$ Other influences include Picasso, who is renowned for his erotic depictions. As curator Greg Hill points out in his essay Norval Morrisseau: Shaman Artist, "Morrisseau admired Picasso 's work and his status as a great artist. "'115

In other world art, the representation of the large penis occurs as an indication of the creative powers posed by the male. The similarities between the Anishnaabe and African worldview and the association of the phallus with fertility and its metaphorical association with creation may have influenced Morrisseau's depiction of the large phallus. This is evident in an Untitled, 1990's drawing on paper from the Vadas collection (see figure 3.4). In this flat two-dimensional image a single male figure is shown in profile. He appears to be nude with the exception of his feet, which are, coloured a solid red. A graphic treatment may indicate moccasins. The lower portions of his legs from the knee downward are

114 Phillips. "Morrisseau's Entrance," 58.

115 Hill. "Norval Morrisseau: Shaman Artist.," 30. 
graphically treated with black horizontal lines, indicating leggings or perhaps tattoos or paint applied on to the body. This same graphic treatment appears on the arms, around the male figure's neck as well as the shaft of the penis. His circumcised penis is disproportionately large, and in a semi erect state, the head of his penis coloured red. The base of the penis and the scrotum are indicated with a black line outlining their contour from which smaller curled lines radiate, depicting pubic hair. Inside the contour line are numerous randomly arranged small black dots. Similar dots also appear on the shaft of the penis; however, here the placement is arranged in an orderly fashion of one in front of the other, perhaps indicating sperm and ejaculation. Sitting on the shaft of his penis is a small —human creature, whose hands and feet mirror the coloured graphic treatment of the larger male figure. Several other small human like creatures appear to be resting on the male figure's arms, in which all but one is in a seated position. All seven of these figures are uniform in that they do not have hair and they face the same direction as the large male figure. Each figure is shown in profile as the black contour line that outlines the eye continues vertically through the centre of the profiled body. The sex of these small beings is curiously omitted. On the head of the large central male figure, a black form line outlines a contour resembling the racks of moose antlers. These antlers are divided into two distinct areas, each coloured differently with the use of colour. The base of each antler is treated with black opaque ink while the remaining upper portion of the antler is then coloured with an opaque red. These antler-like shapes appear to be fashioned from the male figure's hair as small black hatch marks indicate 
hair being pulled away from the scalp, which is further demonstrated by two strands of long hair curling at the base of the neck. It is difficult to determine the significance of fashioning the hair in this manner. This along with the markings on the legs, arms and round the neck can be seen as indicators of the male figure's cultural identity and nationality. On the other hand, they may also be seen as merely symbolic, representing the qualities of endurance and strength that, according to Basil Johnston, are the traits the moose symbolizes for Anishnaabe. ${ }^{116}$

Along the back of the male figure are seven figures positioned, one beside the other, in a vertical line facing the viewer. I believe them to be what Morrisseau refers to as ancestral figures as they resemble figures found in Midèwiwin scrolls and shaman petrogyphs. (see figure 3.5) Three of the ancestral figures have horn-like appendages; one on either side of their head. The heads of these entities are composed of a circular shape, which encloses another smaller circle. The small circles are outlined with a black form line and filled with an opaque red colour, with a small black dot placed in the centre of each circle. The bodies of the ancestral figures' body are divided by a vertical line, which indicates a backbone, while three small horizontal lines intersect the vertical line at regular intervals. This $\mathrm{x}$-ray graphic treatment is a consistent design element used by Morrisseau. The same graphic treatment is applied to the rendering of the bear figure located in the bottom right hand corner of the image. Like the smaller human-like figures held by the male figure, the bear's body is divided by a thin

116 Johnston. Objiway Heritage. 5 
black horizontal line that runs from the circle that forms its eye through to the tail of the animal. Above this black line, on the upper portion of the bear, are small black hatch marks that indicate the bear's pelt. Below this line, there are six vertical lines placed at regular intervals; between each of these lines is a single red dot. The black lines curl inward to create a small spiral. Three vertical lines connect each spiral to the heavy black form line that traces the contour of the bear's body. The use of this visual element is a method demonstrating a very different concept regarding reality in which the known or visible is presented with what is normally not visible. ${ }^{117}$ In depicting both the internal and external realities these two states are seen as being equally important. In the upper right hand corner of the image is a butterfly. A black form line outlines the shape of the butterfly while thinner form lines not only reinforce the shape but are used in a decorative manner to enhance the design. This is especially evident on the wings of the butterfly where spiral lines are used to suggest detail. On the thorax, abdomen and bottom of the hind wings of the butterfly, Morrisseau repeats the same graphic treatment- small, short black lines he used on the male figure. The butterfly's eyes are indicated by circles outlined with a black form line, and filled with a red opaque colour.

Morrisseau's graphic treatment of the background of the image almost appears as an after-thought. In the top two-thirds of the white background we see a single or small groups of two or three black pine or spruce trees seemingly placed to balance the composition. Under these groupings of trees are two

117 Christopher Hume. “The New Age of Indian Art.” Maclean's Magazine. January 22, 1979. 27. 
slightly arched lines, one is black and the other is red. Directly above the nude male figure is a thin form line of red in the shape of a circle outlined, by another form line of black from this, seven smaller black lines radiating outward. It is this small visual element depicting the sun, that provides the greatest insight into what I believe is Morrisseau's visual narrative about creation.

Basil Johnston explains that the circle is considered to be a sign of perfection and is employed as a visual element in the art of Anishnaabe to represent the Creator-Kiche Manito. The presence of the circle is a reminder not only of the Kiche Manitou but can also be viewed as a mnemonic device reminding the viewer of the important role the sun plays in creation and sustaining life. The sun, along with the earth, is continually engaged in the process of creation as witnessed in the changing of seasons. But more importantly Morrisseau's drawing is imbued with the theme of creation and in particular of fatherhood. The male figure's prowess and fertility are suggested by the interplay of the visual elements such as the abundance of pubic hair, large penis and the small dots depicted on the scrotum and the shaft of the penis; which may signify sperm, while also implying Morrisseau's assertion of the sacredness of the penis in the spirit world. An interpretation based on Beth Southcott's statement that the employment of small dots to suggest the sacred is part of Anishnaabe artistic iconography. ${ }^{118}$ This is also an observation made by Elizabeth McLuhan in her analysis of Morrisseau's painting on birch bark Man Changing into Thunderbird

118 Southcott. Sound of the Drum, 80 . 
(1958-60) (see figure 3.6), she writes:

Already there is a foreshadowing of stylistic change in the self- conscious use of the zigzag emanating lines, empty and divided circles and dots, which transcend the decorative speckle effect to designate special power on the pendent medicine pouch around the eagles neck. ${ }^{119}$

This reading would also be consistent in view of Morrisseau's use of this same graphic treatment in his depiction of female genitals, as seen in the image discussed in the previous chapter entitled Mother Earth. For the Anishnaabe the act of creation is seen as an act of selflessness and generosity. ${ }^{120}$ Another testament to the creation motif are the numerous small human like creatures resting on the arms of the nude male figure, while one lone figure sits on the shaft of the male figures penis. Although these small beings could be interpreted as Missabikum (uk) -the little men of iron or metal who live among rocks and who are responsible for the images and inscription that are seen on stone, the presence of the butterfly along with the displayed interest in it by the small figures, implies a different reading. According to Anishnaabe belief, butterflies were placed on earth to make children happy and are seen as representing the spirit of children's play. ${ }^{121}$ Therefore it is more than likely that these small figures represent children.

Perhaps one of the most interesting features of this image is how Morrisseau brings together the past, present and future. The past is implied in the seven

119 McLuhan, Elizabeth "Norval Morrisseau and the Emergence of the Image Makers", in the Norval Morrisseau and the Emergence of the Image Makers exhib. cat. eds. Tom Hill and Elizabeth McLuhan, (Toronto: Art Gallery of Ontario, 1984), 32.

120 Johnston. The Manitous, 4.

121 Basil Johnston. Ojibway Language Lexicon for Beginners. (Ottawa: The Department of Indian Affairs. 1987), 24. 
figures positioned horizontally behind the male figure. As I mentioned before, their composition is stylistically reminiscent of figures drawn on the Midèwiwin scrolls, which are used by practitioners of the ancient society's ceremonies. The presentation of these figures can be seen as symbolically representing the seven grandfathers whom as Southcott writes, are central to Anishnaabe thought. ${ }^{122}$ Southcott explains that the first four Grandfathers represent the spirits of the four cardinal directions east, south, west and north. The fifth Grandfather represents the spirits who dwell in the four layers of the earth, while the sixth Grandfather represents the spirits that inhabit the four layers of the sky. The final Grandfather is fire. ${ }^{123}$ Another reading of presence of these seven figures could be an implied connection to gifts given to the Anishnaabe by the seven Grandfathers, which are wisdom, love, respect, bravery, honesty, humility and truth. ${ }^{124}$ This reading is augmented by the presence of the bear in the lower right hand corner of the image, as bear is a very powerful Manitou in Anishnaabe belief.

The Bear Manitou is a prevalent motif in Morrisseau's artwork. In several interviews given throughout his career Morrisseau reveals the importance of the bear in his own personal life as well as the bear's importance within the Anishnaabe worldview. The role the bear plays in terms of totems/clan differs from the role it occupies as a Manitou. ${ }^{125}$ As noted earlier Anishnaabe extended

122 Southcott. Sound of the Drum, 80.

123 Southcott. Sound of the Drum, 80.

124 Rheult. Midèwiwin Organization of Knowledge, 16.

125 Nancy Lou Paterson. "Shaking Tents and Medicine Snakes: Traditional Elements in Contemporary Woodland Indian Art."

(Artsmagazine Summer 1976.) 
family relationships are based on clans-clan membership is patrlineal. According to Rheault the six clans of the Anishnaabe are: The Bear, Fish, Deer, The Bird, Loon and Crane. ${ }^{126}$ Morrisseau also has a very personal spiritual connection with the bear.

I believe that this drawing from the Vadas collection speaks about the nurturing and creative role of the Anishnaabe male. He is depicted not only as a warrior but as a nurturer; the latter being a gender role that is viewed as feminine in a patriarchal society.

Morrisseau's image, Phallic God in Disguise (1972). (see figure 3.7), is much more striking and, at least on the surface, presents the male nude as powerful and menacing. The power of the shaman is underscored by Morrisseau, through his use of thick contour lines outlining large blocks of bold opaque colours. This painting was made into a limited edition print entitled the Other Side of Shaman. ${ }^{127}$ The title of the print gives us, perhaps some insight into the intent of the artist. Its depiction of aggressiveness and suggested violence implies a power that is almost sinister and lacking in benevolence. It is the antithesis of Clark's impassioned description the Greek male nude "in which the gods, like men, are worshipped for their life giving beauty rather than their death dealing powers."

126 Rheault. Midéwiwin Organization of Knowledge, 16.

127 This painting was made into a limited edition print entitled The Other Side of Shaman. The print is identified as a print $21 / 49$ in the collection of the Canadian Museum of Civilization catalogue number III-G-1500 128 Clark. The Nude, 25. 
These two examples of Morrisseau's male nudes, Phallic God in Disguise and The Other Side Of Shaman, bring to mind a Shaman that inhabits the stories collected by Landes in the 1930's. She reports that the evil shaman was more respected than the good shaman and that the most powerful shaman had achieved his status by playing on the fears of the community. ${ }^{129}$ According to Solomon-Godeau, in the western artistic tradition of the male nude, his strength and virility are implied by props, such as large swords. ${ }^{130}$ Morrisseau's Shaman is the antithesis of the western tradition of the male nudes whose bodies exemplify ultimate perfection in their strict adherence to the mathematical laws of proportion and balance. Morrisseau's Shaman stands before us in profile; his virility is demonstrated by the monumental size of his erect penis. From the base of the penis, pubic hair radiates wildly and in abundance. Again, as with his other images Morrisseau utilizes the $\mathrm{x}$-ray technique. It is curious that the Shaman's penis is the only element in this painting that is depicted using this graphic treatment. Morrisseau's applications of the small black dots that appear consistently on the genitals of his other erotic work are brought to our attention. The curving line that conforms to the interior form of the head of the penis and its spiral configuration is repeated in several of the other elements, such as the Shaman's headdress, one of three medicine pouches around the shaman's neck, and the area between the Shaman's erect penis and his belly. Morrisseau's repetition of the spiral graphic treatment in these elements differs from that of the

129 Landes. Ojibwa Religion, 9.

130 Solomon-Godeau. Male Trouble, 36. 
penis in that there is an additional element; he has applied a blue circle outlined by a red form line at the centre of each of the spirals. This not only creates a sense of balance but it directs the eyes' movement within the frame. We are immediately drawn to the white colour. Lister Sinclair wrote in the Art of Norval Morrisseau, that for Morrisseau, the use of the colour white in a composition is somewhat an anomaly, but when it is used it is to denote spirituality as it represents the totality of colour. ${ }^{131}$ The use of white in Phallic God in Disguise illustrates this point since Morrisseau uses this colour in one of three medicine bags that hangs from the Shaman's neck.

The shaman's body is not that of mere mortal consisting of flesh and blood. He projects an essence that is otherworldly, a reading that is enhanced by Morrisseau's choice of colour ${ }^{132}$ and the technique used in the rendering of the eye. The shaman's body is not the pink flesh of a human but grayish blue tone, and the Shaman's eye is composed of circles within circles, which, according to Southcott, is a graphic tool used by Anishnaabe artists to indicate beings that no longer inhabit our reality. ${ }^{133}$ The ability of the shaman to transform and take on other shapes is implied by the odd shaped appendage that resembles a bird's neck hanging downward from a position that is slightly obscured by the shaman's penis. The appendage contains a similar graphic treatment to that used in the depiction of the Shaman's eye. Again, the Shaman's power is enhanced further through with Morrisseau's use of colour.

131 Lister Sinclair and Jack Pollock. The Art of Norval Morrisseau, 58.

132 Morrisseau uses this same colour in the depiction of his ethereal spirit in the painting Portrait of the Artist with Spirit Self. 
Morrisseau also uses shapes and the interplay between the positive and negative space of the background to create what appears to be narrative that speaks to his belief in the sexual ambiguity of the shaman. In examining the relationship created by juxtaposing the raw sienna colour with ultramarine, it appears that a distinct shape emerges that mimics the gentle slope of a woman's breast and body shown in profile. This interpretation could be seen as the result of a viewer's overactive imagination, but this explanation is made more salient in view of Morrisseau's statement that "all shaman are homosexuals or at least bisexual." ${ }^{134}$ Morrisseau's depiction of androgyny is not confined to the shaman but also found in his depiction of other-than-human as well as human forms.

In an untitled and undated painting from the Vadas collection the androgyny is shown in human form. ${ }^{135}$ Within the conventions of western art history, androgyny has typically been expressed as adolescent or ephebic. In Morrisseau's work the androgyny is often represented as an individual who has both a penis and large breasts as seen in the detail of this untitled painting. (see figure 3.8) In this image, two figures sit facing one another against a background that is yellow in the centre, opaque dark blue on the left side of the image, and light blue colour on the right. Both figures are rendered in Morrisseau's characteristic manner of using a black line to trace the contours of the forms and filling these shapes with bright opaque colours. However, uncharacteristically, the

133 Southcott. Sound of the Drum, 41.

134 Lee Ann Martin and Morgan Wood. Exposed: Aesthetics of Aboriginal Erotic Art, 42. 
black form line is doubled with another colour. For the male nude on the right the black form line is doubled with a blue line with the exception of the head of his erect penis, where the blue form line is replaced by green and filled with an opaque red. The colours Morrisseau uses in the depiction of the head of this figure's penis mirror the colours used to portray the second figure, which are the complementary colours of red and green. The second figure's sex is ambiguous as he/she has both large breasts and is depicted with a flaccid penis. Both figures are adorned with an elaborate headdress type that mimics the head of a fish. Between the two figures is a vine-like plant in which some leaves seemingly metamorphose into birds. This design element is repeated in the depiction of the plant on the right side of the frame, whereas the birds are absent in third plant to the left of the image. These vine-like plants are a common motif in Morrisseau's work and can be interpreted as symbolic representations of the tree of life that so often appears in the sacred scrolls used in the Midèwiwin ceremony. Plants according to Anishnaabe belief were created prior to the animals and the Anishnaabe people. Their sacredness resides in the number of needs and uses, they fulfill; not only are plants food, but they are also medicine. ${ }^{136}$ Together with the birds and elaborate headdresses of the two figures, the sky world, the earth and the underworld are acknowledged and their interconnectivity is emphasized. Observing how Morrisseau's characteristic black form lines trace the contours of all these elements, one notes how the black line of one element flows into the form line of the other.

135 this image is part of the private collection of Gabor and Michele Vadas. No title was given or date. 136 Johnston. Ojibway Heritage, 33. 
Morrisseau's use of colour has always been highly suggestive, although the meanings are not always clearly defined. His use of the two shades of blue in this image are exceptions to this pattern. These two colours are very important to Morrisseau. Given to him in a vision; the light blue signifies the morning sky, while the darker blue is a metaphor for the evening sky, promising unwavering protection as well as spiritual sanction for his actions. Here the use of these two colours implies a spiritual sanction of the sexual intimacy between these two figures. The image depicts a sexually intimate gesture; the male /female nude reaching forward to touch the erect penis of the other male figure. What is curious is that it is the feminized male/female that appears to be initiating this exchange; he/she is not a passive participant. Morrisseau has also chosen to depict the anus of this being in a similar manner in which he depicts the female vagina. This can be seen as a reference to what ethnographers, and more recently anthropologists, have acknowledged as the presence of gender variant sexualities among Aboriginal people. This concept will be discussed in greater detail in connection with works by Morrisseau that explore this diversity in the following chapter.

As I have noted, the classic ephebic depictions in western art history are regulated by a tradition that dates back to ancient Greece, and served as a counter-narrative to the image of the virile-hyper masculine male. Together these culturally sanctioned masculinities reinforce a binary construction of male 
sexuality and the primacy of the masculine over the feminine that is still with us as other scholars have stated. The appreciation of the male body as an object of erotic contemplation has gone relatively undetected. As MacKinnon has pointed out, when the male nude's objectivity cannot be denied there is a tendency in western art practice to emphasize their activity as demonstrated by the virile hyper masculine representations. ${ }^{137}$ This explains the proliferation of the seminude male engaging in athletic endeavors and combat. These representations furthermore, spill over from elite cultural institutions such as the art gallery and museum into popular culture, as seen in action movies and video games. With the advent of the women's movement and the increased visibility of alternate sexual and gender identities a more rigorous examination of these constructions of masculinities has resulted. Solomon-Godeau points out that contemporary representations of the masculine " reveal significant correspondence to older visual paradigms of ideal masculinity." ${ }^{138}$

I have argued, in contrast, that Morrisseau's depiction of the male nude reinscribes neither the binary construct of the heroic virile male nor the feminized ephebic. In his images the male nude is exposed as a complex construction that combines the masculine and the feminine. The strict delineation in which the patriarchal order is grounded gives way to a more complex construction. His images deny western categorizations, and speak of a different understanding regarding the construct of male sexuality. His imagery reflects a continuum of

137 MacKinnon. Uneasy Pleasure, 22.

138 Solomon-Godeau. Male Trouble, 22. 
possibilities regarding gender identity, but he also explores how this is expressed in terms of desire and sexuality. As early as the 1970's, as we have seen in the image, Other Side of Shaman, Morrisseau questioned constructs in which sexualities must be identified as either heterosexual or homosexual. This will be the topic of the next chapter. 


\section{Trickster Marries Chief's Son. ${ }^{139}$}

Trickster now took an elk liver and made a vulva from it. Then he took some elk's kidneys and made breasts from them. Finally he put on a woman's dress. In this dress his friends enclosed him very firmly. The dresses he was using were those that the woman who had taken him for a raccoon had given him. He now stood there, transformed into a very pretty woman indeed. Then he let the fox have intercourse with him and make him pregnant, then the jaybird and finally, the nit. After that he proceeded to the village.

Now, at the end of the village, lived an old woman and she immediately addressed him saying, "My granddaughter, what is your purpose in traveling around like this? Certainly it is with some object in view that you are traveling!" And Trickster assured her it was, and replied, "Grandmother, I have come to court the chief's son." "Alright, my grand-daughter, I will inform the people about it." Then the old woman went outside and shouted, Ho! Ho! There is someone here who has come to court the chief's son." This, at least, is what the old woman seemed to be saying. Then the chief said to his daughters, "Ho! This clearly is what this woman wants and the reason for her coming; do, my

\footnotetext{
139 This story was recorded by Paul Radin in Winnebago hero cycles: A Study in Aboriginal Literature. Another version of this same story was collected by Victor Barnouw between 1941 and 1944 and recorded in Wisconsin Chippewa Myths and Tales And Their Relation to Chippewa Life. (Madison: University of Wisconsin Press. 1977), 106.
} 
daughters, go and bring your sister-in-law here." Then they went after her. She certainly was a very handsome woman. The chief's son liked her very much. Immediately they prepared dried corn for her and they boiled slit bear-ribs. That was why Trickster was getting married, of course. When this food was ready they put it in a dish, cooled it, and placed it in front of Trickster. He devoured it at once. There she (Trickster) remained.

Not long after that, Trickster became pregnant. The Chief's son was very happy about the fact that he was to become a father. Not long after that the Trickster gave birth to a boy. Then again he became pregnant and gave birth to another boy. Finally, for the third time he became pregnant and gave birth to a third boy. 


\section{Chapter Three: The Alternate}

No Indian was ever a homosexual or sex crazed person there were no rapes or other sexual things that we find today among people. ${ }^{140}$

Norval Morrisseau (1965)

...a homosexual is one of the most gifted persons there is. I think all shaman are homosexual or anyway bisexual. ${ }^{141}$

Norval Morrisseau (1979)

These two quotes both uttered by Morrisseau and seemly contradictory, are both loaded statements if voiced separately. By juxtaposing them I seek to bring forward both a communal history and the effects of that history on the lived reality of an individual. Although Morrisseau has never openly identified himself as being homosexual, can we infer from them that his self-identification as a shaman also presupposes his homo or bisexual sexual orientation? Additional evidence of this is provided by the body of erotic images he has created which depict sexually intimate interactions between men. ${ }^{142}$ For lack of a more culturally accurate term these works of art would be classified as being homoerotic. Some may view his reluctance to identify himself as a homosexual as homophobic, and that would certainly seem to be the case when we

\footnotetext{
140 Morrisseau. Legends of My People. typed manuscript, 10.

141 Lister Sinclair and Jack Pollock. The Art of Norval Morrisseau, 42.

142 although the author was given the opportunity to view these and take digital photography for her own research purposes. Morrisseau's

representatives have requested that these images no be made public at this time.
} 
considered another statement from Morrisseau's book Legends of my People the Great Ojibway, in which he states, "no Indian was ever homosexual or sex crazed. ${ }^{.143}$ Historical records from a number of sources indicate the existence of the berdache ${ }^{144}$ among many Aboriginal communities. The berdache was an alternative gender role that was considered neither male nor female but rather, a third gender. If Aboriginal communities accepted these individuals as members of the community, we might ask why would Morrisseau be reluctant to embrace this identity and deny the existence of homosexuality within the Aboriginal community? Is Morrisseau's statement the result of internalized homophobia and a desire to negate the stereotype that, to this day, curator Lee Ann Martin characterizes as a view of the Aboriginal person seen as "being wanton in body and sexual"? ${ }^{145}$ If this is true, Morrisseau's reluctance could be attributed to the attitudes non-Aboriginals have held towards an Aboriginal person who did not conform to the gender dichotomy construct of western society which resulted in Aboriginal informants and communities often denying the existence of Berdache person. This factor would have been combined with the impact of the missionization, which had often resulted in the internalization of Judeo-Christian beliefs and attitudes that classified the berdache person as a homosexual, and thereby considered both an abomination and sin against nature. In light of these

\footnotetext{
143 Morrisseau. Legends of My People, 10.

144 Berdache is a French word that when translated means prostitute. This term was ascribed to Native Americans who are biological male but participate within the community performing the gender roles of a female by early ethnographers and social scientists. The term has come under criticism. Will Roscoe reports that contemporary Aboriginal gays and lesbians adopted the term Two Spirits as a reflection of the non-western origins of their identities, and to recover the traditions of alternative genders. See the Introduction to Changing Ones: Third and Fourth Genders in Native North America and Sabine Lang's Two-Spirit People: Native American Gender Identity, Sexuality and Spirituality.

145 Lee Ann, Martin. Personal communication March 19, 2004
} 
circumstances, it is understandable than Morrisseau would feel reluctant to openly declare his sexual orientation. It is evident in his work and his words that the Roman Catholic Church has had a significant impact on his life. The doctrine of the Church was a source of conflict for Morrisseau, which was compounded by his having being sexually abused as a child by priests, when he attended a Roman Catholic residential school. One can only imagine the confusion that would result from this abuse. Consequently, it is not surprising that as an adult, years later Morrisseau would state, "When I was a Christian I was often guilty. But that changed as soon as I came back to my Indian beliefs. There was no sin with the Indian people." ${ }^{146}$ Not only was homosexuality a sin against the church, it was also illegal in Canada. Until 1969, homosexual acts between two men were considered a criminal offense that could result in a sentence of life imprisonment. ${ }^{147}$

The question then becomes what occurred within that fourteen year span between 1965 and 1979 that would result in Morrisseau seemingly doing an about face to the point where he could declare that the orientation of the shaman is neither homosexual or heterosexual but rather bisexual. Was this a personal revelation influenced by the historical attitudes about sex in Canada and the United States? The impact of the New York's Stonewall riot in June of 1969

\footnotetext{
146 "The Pride of Norval Morrisseau." Weekend Magazine. July 21. 1979. Nation Gallery of Canada Artist Files. Norval Morrisseau. 147 In 1965 Everett Klippert was interrogated by the police as part of an arson investigation in the Northwest Territories. Klippert was arrested after admitting that he had had sex with other men. When psychiatrists determined that Everett Klippert was unlikely to stop having sex with men, he was declared a dangerous offender and sentenced to life in prison. He was released from prison in 1971. for more information see http://archives.cbc.ca/IDC. 1-69-599-3226/life_society/gay_lesbian/clip2. Accessed 01.04.2006
} 
reverberated across the border into Canada's major urban centers, providing impetus for Gays and Lesbians to organize and lobby the federal government for changes in the criminalization of homosexual acts between men. Toronto and Vancouver, two of Canada's largest urban centres, became centres for Gay and Lesbian political and social activity. In the large urban centres the cover of anonymity existed, and it appears that during this time Morrisseau, living in Toronto, experimented and explored his sexuality. Jack Pollock, Morrisseau's agent during his early years of success in Toronto, described Morrisseau's sexuality as "extremely explorative, and dangerously experimental." ${ }^{148}$ In an article written for Weekend Magazine in July of 1979, the author quotes Morrisseau as saying that "As far as sex was concerned that he had tried everything under the sun." ${ }^{\text {149 }}$ Although attitudes regarding sexuality had been relaxing in the 1980's, the expression of sexuality that deviated from the norm still met with a great deal of opposition. To accept these explanations as a way of resolving the apparent contraction between what Morrisseau wrote in 1965 and what he said in 1979 seems plausible enough. However, it is important not to ignore the importance of a traditional Anishnaabe worldview, with in which, as we have seen a gender and sexuality are not defined exclusively in terms of male and female, nor for that matter in terms of heterosexuality or homosexuality. These dichotomies are western social constructs in which Aboriginal people were forcibly indoctrinated by institutions such as churches and schools. Gabor Vadas, paraphrasing Morrisseau, stated in an interview for the recent film, $A$

148 "The Pride of Norval Morrisseau." Weekend Magazine. July 21. 1979. Nation Gallery of Canada Artist Files. Norval Morrisseau. 149 Paul Carvalho. A Separate Reality: The Life and Times of Norval Morrisseau. Perception Films INC. 2004 
Separate Reality: The Life and Times of Norval Morrisseau "Norval sees no reason he should apologize for anything sexual." He continues by stating further, "He made it very clear to me that he is neither gay, straight or bisexual. Everybody could be all of that from Norval's point of view." 150 Gabor's statement not only reveals Morrisseau's rejection of labels, but, I contend, questions the authority and universality of a construct in which sexuality, gender and identity are based on one's biological sex. This view is extremely important for understanding Morrisseau's erotic artwork, allowing us to reclaim an understanding based in an Anishnaabe worldview. Furthermore, according to anthropologist Sabine Lang, a similar worldview is shared by many Native American cultures, which also accepts gender variant individuals. As Lang writes, they "realize and appreciate transformation, change, and ambiguity in the world at large, as well as individuals. ${ }^{151}$ From this perspective Morrisseau's assertion that "no Indian was ever a homosexual..." is accurate from an Anishnaabe point of view.

Ojibwa worldview included a berdache concept known as the agokwa. This is the Anishnaabe term for the biological male that preformed the gender roles of a woman. The term for female is okitcitakwe or warrior woman. ${ }^{152}$ The agokwa was not a homosexual because the Anishnaabe did not consider the agokwa as being a 'deviant' male, they were neither male of female; they belonged to a third

150 Paul Carvalho. A Separate Reality.

151 Sabine Lang. "Various Kinds of Two-Spirit People: Gender Variance and Homosexuality in Native American Communities." In Two - Spirited People: Native American Gender identity, Sexuality and Spirituality, 114.

152 Roscoe. The Changing Ones, 214. 
gender. As Lang points out, early ethnographers represented the relationships between an agokwa and a man as homosexual in their field work because they failed to see that, from an Aboriginal perspective, these relationships involved two people of the same sex but of differing genders. As anthropologist Will Roscoe observes, "Because berdaches were considered members of a distinct gender, native epistemologies classified relationships with them differently. ${ }^{153}$ As Sabine Lang writes so succinctly "If you are a man and you have a sexual relationship with a 'berdache,' you are not having sex with another man. You are having sex with a 'berdache'. So the partners of the berdaches technically are never homosexual because they are not having sex with their same gender." ${ }^{154}$ Roscoe also adds that, generally, there is a distinction between reproductive and non-reproductive sexual acts, and he writes that non-reproductive sex was valued in its own right and was engaged in for pleasure and emotional rewards; sexual acts, were, therefore not relegated only to the procreative function. In some instances it was believed that that through sexual intercourse a man could obtain desirable attributes possessed by the agowka. Such is the case of Objiway agowka and accomplished warrior known as Ozaw-wen-dib. Men believed that by having an intimate connection with him, one could acquire the famous agowka's courage and fighting ability. ${ }^{155}$ However, sexual activity was only a very small part of the agokwa's gender role. As among many other tribes, among the Ojibwa, these individuals enjoyed special respect or status within the

\footnotetext{
153 Roscoe. The Changing , 10.

154 Lang. "Various Kinds of Two-Spirit People," 205.

155 Roscoe. The Changing Ones, 9.
} 
community because of the role visions or dreams played in determining the agowka's identity. Their identity as agokwa was viewed as a result of the divine intervention of other- than-human-beings. ${ }^{156}$ Anthropologists Callender and Kochems, report that among the Ojibway another factor that contributed to becoming an agokwa was by the child choosing to participate in female activities over male activities. ${ }^{157}$ Historian Bobbalee Ann Shuler has explored differences in interpretation of sexual behavior between Europeans and traditional Aboriginal people. She writes that in many Aboriginal communities, one's gender classification was not determined on the basis of sexual activity but rather by the person's spirit, character and desire, because the body is recognized as a temporary state and houses the soul-spirit. ${ }^{158}$ In a culture in which metamorphosis and the instability of the outer form is so prevalent in the oral traditions, it is evident that the inner reality is, as Southcott has observed, “ paramount and the outward appearance is only an incidental attribute of being." 159 This notion is central to understanding Morrisseau's assertion regarding his sexual identity and his rejection of western constructs and labels. His images of sexual intimacy among males not only embody these notions but also often speak of a spiritual sanction of the relationships between the agokwa person and male lovers.

The image Indian Erotic Fantasy, which was included in the Lee Ann Martin and

156 Roscoe. The Changing Ones, 14.

157 Charles Callender and Lee M. Kochems. “The North American Berdache.” Current Anthropology. Vol 24. No.4 (Aug- Sept 1998 ), 452. 158 Bobbalee Ann Shuler. "More Sin than Pleasure: A Study in Cultural Conflict." (PhD dissertation., University of Wyoming. 1994$), 33$. 159 Southcott. The Sound of the Drum, 38. 
Morgan Wood, "Exposed" exhibition, is one of the images that make visible both the sexual and the spiritual connections between two people. (figure 4.1) Enclosed within a cocoon, the two male figures exemplify the notion of metamorphosis in both a figurative and a literal sense. A number of visual elements underline the interconnections between these beings. Their sexual desire for one another is indicated by their mutual state of arousal, as both figures are depicted with an erection. The background of two shades of blue, (a colour whose significance has already been discussed) speaks of both protection and of a spiritual sanction of this relationship. The two nude figures are shown in profile, their bodies outlined with heavy black lines. Although they are represented as two distinct persons they appear conjoined at the shoulder. Each figure is filled with different opaque colours, indicating the differing racial backgrounds of these individuals. The figure on the left depicts an Aboriginal male against the darker shade of blue, the colour that Morrisseau has explained as representing the night sky. From his neck hangs a necklace composed of circles and ovals outlined with a black form line, using the light blue, dark blue, yellow, red and orange to form the design, this same graphic treatment is repeated in the formation of this individual's ear lock. He also wears an armband and two wristbands, outlined in the characteristic black form line. These differ from the necklace and ear lock in that the shapes are elongated, mimicking an ovoid, while the colours used are a combination of the two shades blue with the addition of lavender. The second figure is white and nonAboriginal. Morrisseau employs a number of visual elements to emphasize the 
interconnection between these two individuals; a connection that is physical, emotional, mental and cognitive. These small black undulating lines are like electric circuits passing between these figures tracing an exchange of energy. It is an image that portrays more than physical attraction as one figure reaches upward to touch the beating heart of the second male figure, who offers no resistance as his own hand is seemly supporting and welcoming the intimate act.

Between the two figures near the bottom of the frame is a series of concentric circles of lavender, turquoise, yellow, and red colours respectively. These circles are enclosed by a black form line which also acts as a hub for a number of lines radiating outward and connecting the two figures. Following an ascending line along the posterior of the male figure on the right, the patterning of the concentric circles is repeated with minor variations in both the colour and size. The larger of these circles runs parallel to the non-Aboriginal male's calf, buttocks, torso and neck. These larger concentric circles, Martin and Woods inform us, signify the "five stages of life one must pass through in order to free the soul." ${ }^{160}$ A series of seven small concentric circles of yellow and blue do not follow a pattern but are randomly placed on the body of the fair skinned male; on the shaft of his penis, his buttock, wrist, bicep, shoulder and chin. The seventh one differs from the others in that the colour blue has been added which along with it's placement - in the centre of this male figure's heart, indicates that it is more significant than the others. 
In his depiction of the caterpillar whose body curves around the lovers, and physically encases them; Morrisseau creates a narrative rich in symbolism. Its presence speaks of transformation and metamorphosis. In a sense it represents death as a temporary state that evolves into a different state of being. Similarly, the two male figures seem to merge together physically forming a symbiotic existence. Morrisseau's Indian Erotic Fantasy visually illustrates a Platonic ideal, and his thoughts concerning the nature of love so eloquently expressed in the verbal sparing between Aristophanes and Eryximachus, in The Symposium;

Do you desire to be wholly one; always day and night to be in one another's company? for if this is what you desire, I am ready to melt you into one and let you grow together, so that being two you shall become one, ...there is not a man of them who when he heard the proposal would deny or would not acknowledge that this meeting and melting into one another, this becoming one instead of two, was the very expression of his ancient need. ${ }^{161}$

Whether or not Morrisseau was cognizant of Plato writings on the nature of love, his image expresses the same need for two to meld into one, a notion that has transcended time, as evident in popular culture phenomena from Hallmark cards to Hollywood movies. The title of the image may betray its overall sentiment, for Morrisseau's use of the word "fantasy" maybe intended to imply, an unattainable state.

In contrast to Indian Erotic Fantasy (nd) the image Life Figures (1985) (figure 4.2 ) is much more graphic in its depiction of sexual intimacy between members of the same sex. Although both images illustrate similar Anishnaabe notions regarding transformation and metamorphosis, Morrisseau captures an

160 Martin and Morgan Wood. Exposed, 41. 
impassioned moment between lovers, whose urgency is made apparent by their semi-clothed state. This image is devoid of the romantic sentiment of the previously discussed image. My question however, is what does this narrative reveal in relation to an Anishnaabe worldview and how does it reflect Anishnaabe attitudes towards sexuality? I would argue that it disrupts western society's social construction of homosexual pairings that reinforce a patriarchical and heterosexual ideal in which sexual partners consist of an active (male) and a passive (female).

Although, Morrisseau relies on the use of colour to inform the reading of this image, namely his use of the two shades of blue in creating the backdrop to denote spiritual sanction, what becomes evident in this image is its depiction of instability of one's outer form - the notion of transformation. Unlike Indian Erotic Fantasy the metamorphosis in this image is literal rather than implied. This acrylic painting shows two biological males engaging in the sexual act of anal penetration. However, one of the figures displays physical characteristics that are both human and those other-than-human; it is a composite body melding together persons that inhabit the sky world, the underworld, and earth world. He appears human but from his lower back the thunderbird emerges, while one wing morphs into the head of a fish— together these other-than-human shapes form this unusual beings torso, while the hands that embrace his human lover are those of a bear. Bodies contort as the lovers exchange a kiss. In the lower right portion of the image another fish grazes against the human lover, its open jaw 
and menacing show of teeth is perhaps a reminder of the unpredictability of relationships.

Although, this image seems to be very a straight forward depiction of two biological males engaging in a sexual act, it is complicated by the fact that Morrisseau has chosen to portray one of the males as having the ability to transform himself, which is often associated with the supernatural. Is this otherworldly being a shaman? If we consider the assertion Morrisseau makes regarding the inherent bisexual nature of the shaman, what gender category does the shaman occupy? In a western social construct the male takes on the active role while the passive role is associated with the female. How does the positioning of the individuals in this image disrupt or confirm expectations in terms of active and passive roles? We need to consider the recorded accounts of individuals who describe how the power to perform certain ceremonies were given to them. In Legends of My People: The Great Ojiway Morrisseau recorded a story in which a man received the power to perform the shaking tent ceremony by allowing "the devil" [sic] blow the power to conduct this ritual into him through his rectum. He wrote: "I felt the power going though me and coming out my mouth. I could not describe how I felt but when it was all over I was told I was a full-fledge conjuror and [sic] that I am now." 162 If this is an indication of how one obtains power, it suggests how the Objiwa agowka Ozaw-wen-dib passed on his attributes as an accomplished warrior. It suggests that the agokwa, who was 
biological male but took on the gender roles of woman, was not confined by those roles, but rather, that circumstances dictated whether the agokwa fulfilled an active/male role or passive/female role. From historical accounts we know that an agokwa person was active in pursuing male sexual partners, ${ }^{163}$ but we have no information as to whether the agokwa person occupied the active or passive role in sexual acts. Nevertheless, it is apparent that the western construct in which sexual pairings consist of an active/male partner (penetrator) and a passive/female partner cannot fully explain the profusion of sexual pairings that occur in Morrisseau's work.

The question also arises of whether this is a self-portrait of Morrisseau as shaman, and provides insight into how he interprets the Anishnaabe notion of the fluidity of gender. Perhaps the title in its simplicity is the key to unlocking Morrisseau's intent to depict one's biological sex as an incidental attribute of being. Although it is difficult to explain the contemporary identity of Aboriginal Gays and Lesbians because of the influence western ideologies have had on the formation of these identities, however the adoption of the term Two Spirit by contemporary Aboriginal gays and lesbians reflects the non-western origins of their identities, and desire to recover the traditions of alternative genders. ${ }^{164}$ Morrisseau through his imagery reveals that the roots of these identities are founded within the Anishnaabe culture.

163 John Tanner. A narrative of the captivity and adventures of John Tanner (U.S. interpreter at the Saut de Ste. Marie) during thirty years residence among the Indians in the interior of North America / prepared for the press by Edwin James. Publisher. Minneapolis, Minn: Ross and Haines, 1956.90. 164 According to Sue Ellen Jacobs et al the term "two spirited" was coined in 1990 during the Winnipeg Native American /First nations gay and lesbian conference. See Two-Sprit People, 2. 
Life Figures, as we have seen, explores themes of transformation, change and the ambiguity of form. A number of images from series of pen and ink drawings completed in 1999 and earlier in the decade explore these themes in great depth. These images are very graphic in their portrayal of sexual acts between men and between men and other-than-human-beings. At first glance it would be easy to label these as images of bestiality and homoerotic. However, as the discussions of Indian Erotic Fantasy and Life Figures have illustrated, such a label would fail to recognize the Anishnaabe construct regarding the fluidity of gender and its expression in terms of sexual pairings.

These untitled ink drawings visualize the very complex relationships between other-than-human-being and the Anishnaabe. Unlike Morrisseau's paintings, where his skilful use of colour, strong arabesque form lines and ovoid shapes create abstract forms and patterns, these images expose and capture a raw essence that borders on the transgressive. In one drawing on paper (see figure 4.3), we see an example of Morrisseau's visual exploration of the complexity of these relationships. This image depicting anal penetration between two biological males is confrontational yet, it engages the viewer on many levels.

These are not ordinary beings. Like Life Figures, these figures meld together two types of beings displaying physical characteristics that are both human and those-other-than-human. Their metamorphoses allude to the spiritual power of 
these creatures'. The drawing expresses pictorially, the principle observed by Overhalt and Calicotts in their examination of Anishnaabe oral traditions that "appearances can be deceptive, for power resides not in a tangible outward form, but rather in some intangible inner essence." 165 In this image Morrisseau brings together the sacred and the profane. On the right side of the image a male figure inserts his disproportionately large erect penis into the anus of the second male figure. This male figure appears to be human in form, as well as possessing physical characteristics of an otherworldly being; the thunderbird. He is of the sky world, the protector who possesses supernatural powers, the Medicine pouches he wears around his neck augment the suggestions of powers. Unlike his early paintings in which his subjects exhibit elaborate headdresses, in this drawing Morrisseau adorns the crown of the figure's' head with a scaled down version of a thunderbird headdress, consisting of a birds head and neck. In the far right hand corner adjacent to this kneeling being are two small, almost caricatured renderings of a bear standing on it hind legs looking down on a bird. The presence of these other-than-humans is balanced by the two flowers in the opposite bottom corner and a small butterfly. Their placement is perhaps an afterthought, and they seem insignificant in comparison to the second male figure, whose splayed legs, and position identify him as occupying the passive positioning in this sexual act. Unlike the shape-shifting thunderbird, the other worldliness of the second male figure is implied, by enclosing the representation of a human male within the image of a bear, it is a variation on the $x$ ray graphic

165 Thomas Overholt, and J Baird Callicott. Clothed -In - Fur and Other Tales: An Introduction to an Ojibwa Worldview. (Washington, D.C.: University Press of America,1982), 142. 
technique that is so prevalent in Morrisseau's early paintings. This graphic treatment enables Morrisseau to depict simultaneously both an interior and an exterior reality.

The bear and the thunderbird; as other-than-human-beings both play very significant roles in his life. They are sources of power and identity; while Morrisseau's name is Copper Thunderbird, the bear is his spirit guide or personal guardian spirit. Within the Anishnaabe worldview both of these beings are held in very high esteem. Anthropologists Joan and Romas Vastokas write that among the Algonquian speaking people, the thunderbird is deemed the "supreme fighter," ${ }^{166}$ an attribute affirmed by Morrisseau in Legends of My People the Great Ojibway, where he writes that thunderbirds were the protectors of the Ojiway. ${ }^{167}$ The bear, as we have seen in previous chapters, occupies a principal role in the Anishnaabe mythology, as the being that brought both the Midèwiwin ceremony and medicine to the people, while also being endowed with the characteristics of strength and courage. If then, this drawing depicts an exchange of power, who is receiving the power? As mentioned previously, anthropologist Will Roscoe points out that non-reproductive sex was engaged in for pleasure and emotional rewards. Consequently, one can extrapolate that this image simply depicts an agowka with his lover, and the presence of the other-than-human-being elements are there to provide clues to the identity of these individuals. Perhaps this image is autobiographical. While we can only speculate about the meaning and

166 Joan and Romas Vastokas. Sacred Art of the Algonkians; A Study of the Peterborough Petroglyphs. (Peterborough: Mansard Press. 1973), 91. 167 Morrisseau. Legends of My People, 11. 
Morrisseau's source of inspiration for this image, to reduce this image solely to homoerotism would be simplistic and too narrow in interpretation.

Overhalt and Calicotts assert that in the oral traditions of the Anishnaabe people, animals representing other-than-human-beings are portrayed as having the same emotional and cognitive capabilities as human beings. A number of Anishnaabe stories relate instances where other-than-human-beings enter intimate relationships with humans, as well as instances in which sexual intimacies occur. They reinforce the notion that our external manifestation, whether human or other-than-human-being is inconsequential, and that it is the quality of our inner being or essence that is of importance. Although this image along with a number of images in the Vadas collection are very explicit in sexual content, the basic premise is that the categories of human and other-than-human and biological sex are open and not categorically exclusive.

Sexual couplings between humans and those other-than-human are a common theme of many Anishnaabe legends. As Franchot Ballinger, observes in her examination of sex and gender in Native American trickster stories, sexual pairings between humans and those other-than-human "reaffirm our relationship to the world of non human." 168 These stories illustrate how deeply embedded these notions of interdependence are, while often displaying the superiority of those-other-than-humans to humans. The difficulty in accommodating this notion

168 Franchot Ballinger. "Coyote, He/She Was Going There: Sex and Gender in Native American Trickster Stories." Studies in American Indian Literatures. Series 2. Volume 12, Number 4 Winter 2000. endnote \#6 
in mainstream Canadian society was indicated by the revisions Morrisseau was asked to make to the commissioned mural for Expo '67 Indian Pavilion. Originally, he envisioned a mural depicting a scene from a legend of a human mother suckling her offspring; a human child and a bear cub. However, in the end the bear cub was conspicuously placed to the side, while only the human child remained at the mother's breast. Although the image was not overtly sexual, it implied a sexual pairing between a human and a bear. This illustrates the notion that the hierarchical division between the human and other-thanhuman is absent from the Anishnaabe understanding of the world.

In dealing with this subject matter is important remind oneself that very few cultures have defined individuals solely in terms of their sexual orientation or sexual behavior. ${ }^{169}$ The Anishnaabe are not an exception to this, sexual behavior was a very small part of the agokwa role within the Anishnaabe community. The agokwa individual took on the role of a woman, and in many instances this also included choosing a same sexed person as their sexual partner. As Roscoe informs us this was not always the case. In some tribal communities under certain circumstances a male berdache had relationships with women, whereas other berdaches were not sexuality active at all. ${ }^{170}$ Morrisseau's erotic depictions call into question the usefulness of what can be defined as the categorically exclusive terms in which identity is delineated. His images question the binary constructs of homosexual and heterosexual even if

169 for more information on other non western cultures see Dominique Fernander. A Hidden Love: Art and Homosexuality pages 158-181, or James Smalls Homosexuality in Art. Chapter 4 
they do not resolve it. Morrisseau's reluctance to identity himself in terms of these western constructs is not only a rejection of these labels, but as I stated earlier firmly establishes the roots of his identity within an Anishnaabe worldview. It is a worldview that recognizes and appreciates ambiguity, transformation and the instability of one's outer form. 


\section{Conclusion:}

When two worlds collide there is always the possibility that only one world will survive. Fortunately in the body of art I have considered in this thesis, this has not been the outcome. Morrisseau's erotic imagery has left us a legacy that enables us to critique the depiction of the nude and question the social hierarchies embedded in depictions of the nude and sexuality.

In the first two chapters of this inquiry I examine the archetypes of the female nude and male nude. In comparing and contrasting the narratives that are embodied in these social constructs, I contend that very different ideas and beliefs emerge regarding sexuality and gender. For example in the chapter examining the depiction of the female nude by western male artists I assert that the female nude has historically been utilized to propagate an ideology that subjugates and controls women's sexuality. This becomes evident by comparing and contrasting the narrative embodied by the female nude created by western male artists with the narratives that Morrisseau's female nude embodies.

I made a similar argument about the male nude. Socially sanctioned depictions of the male nude speak of a sexuality that is defined in terms of a binary construct. Western representations delineate the male nude as being the virile heroic male or the feminized youth. Morrisseau's depiction of the male nude 
speaks of masculinities that transcend the active/ passive binary construct found in the western historical construction of the male nude. These constructs like those of the female nude embody an ideology. It is an ideology that defines sexuality in terms of a strict differentiation of heterosexual from homosexual. Morrisseau's depiction of the male nude merges and blurs these boundaries.

In the final chapter on alternative genders, we begin to fully appreciate the Anishnaabe belief in the body as in a contingent state that is capable of change and transformation. Morrisseau's imagery illustrates the interrelations between human and other-than-human-beings. Equally, his depictions express one of the basic tenets of the Anishnaabe worldview that the essence of a being is paramount, that one's sexuality is not determined solely by their biological sex, nor are other sexualities defined in terms of the binary construct that reinforces the notion of active/ passive. Morrisseau's feminized androgyny is shown as actively participating in intimate exchanges, offering an alternative to the strict delineation presented by western constructs. Gender and how one expresses their sexuality are much more fluid.

Throughout this study I have stated that Norval Morrisseau's erotic images speak of a different understanding regarding the body, gender and desire. His erotic imagery challenges widespread notions in western society by putting forward alternatives grounded in an Anishnaabe worldview. I have argued that by examining Morrisseau's erotic artwork from an Anishnaabe perspective that his 
erotic depictions challenge the meta-narratives of the mainstream regarding sexuality, gender and the body. ${ }^{171}$ Western notions regarding the body, gender and sexuality are often touted as expressing the innate nature of human beings, I believe what Morrisseau makes evident is how unstable these notions are. His depictions demonstrate that the authority of the meta-narratives are not absolute nor are they universal.

This study only begins to explore the erotic depictions of Norval Morrisseau, there remains a large body of erotic images that has not been discussed and deserves consideration. I also continue to receive information regarding exotic images in private collections which explore themes that I did not develop in this thesis, for example, Morrisseau's erotic depictions of heterosexual couplings.

During this project the importance of community-based knowledge and in particular its place with in the academic realm became increasing evident to me. This study is indebted to the exhibition Exposed : the Aesthetics of Aboriginal Art and the exhibition the Art of Norval Morrisseau, the Writing of Basil Johnston. Their use and awareness of community-based knowledge demonstrates how important it is for Aboriginal perspectives and an Aboriginal voice to be apart of the discourse within the discipline of art history. It has been my intent that this thesis would become a part of this discourse.

171 Barthes. Mythologies, 129. 
When the subject of a thesis is a living artist there is always a challenge that is absent when the subject is a concept, or idea. It is not a sense of added responsibility to get it right but rather to connect with that person on some level, to reach an understanding, and acknowledge what they have chosen to share with you through their imagery. I am reminded of my meeting with Morrisseau, Gabe and Michele. After spending the day together, Gabe and Morrisseau kept me company, while I waited in the queue for the ferry that would take me back to the mainland. We talked about my thesis and I shared my thoughts with them. I was especially excited about the images I was shown earlier in the day, images I felt embodied an Anishnaabe worldview regarding sexuality, gender and the body. Our discussion was interrupted when both Gabe and I saw Norval motioning that he wanted to say something. Gabe leaned down towards Norval, so he could hear what Norval so urgently wanted to say. Gabe moved his head up and down as he listened to Morrisseau. I had trouble understanding what Morrisseau was trying to say. Gabe must have noticed that I did not understand, because he turned to me and said "Norval just wants to say that he thinks you are on the right track." I looked at Norval sitting in his wheelchair and I smiled at him, and for a moment I thought I saw Coyote smiling back at me. 


\section{Appendix A}




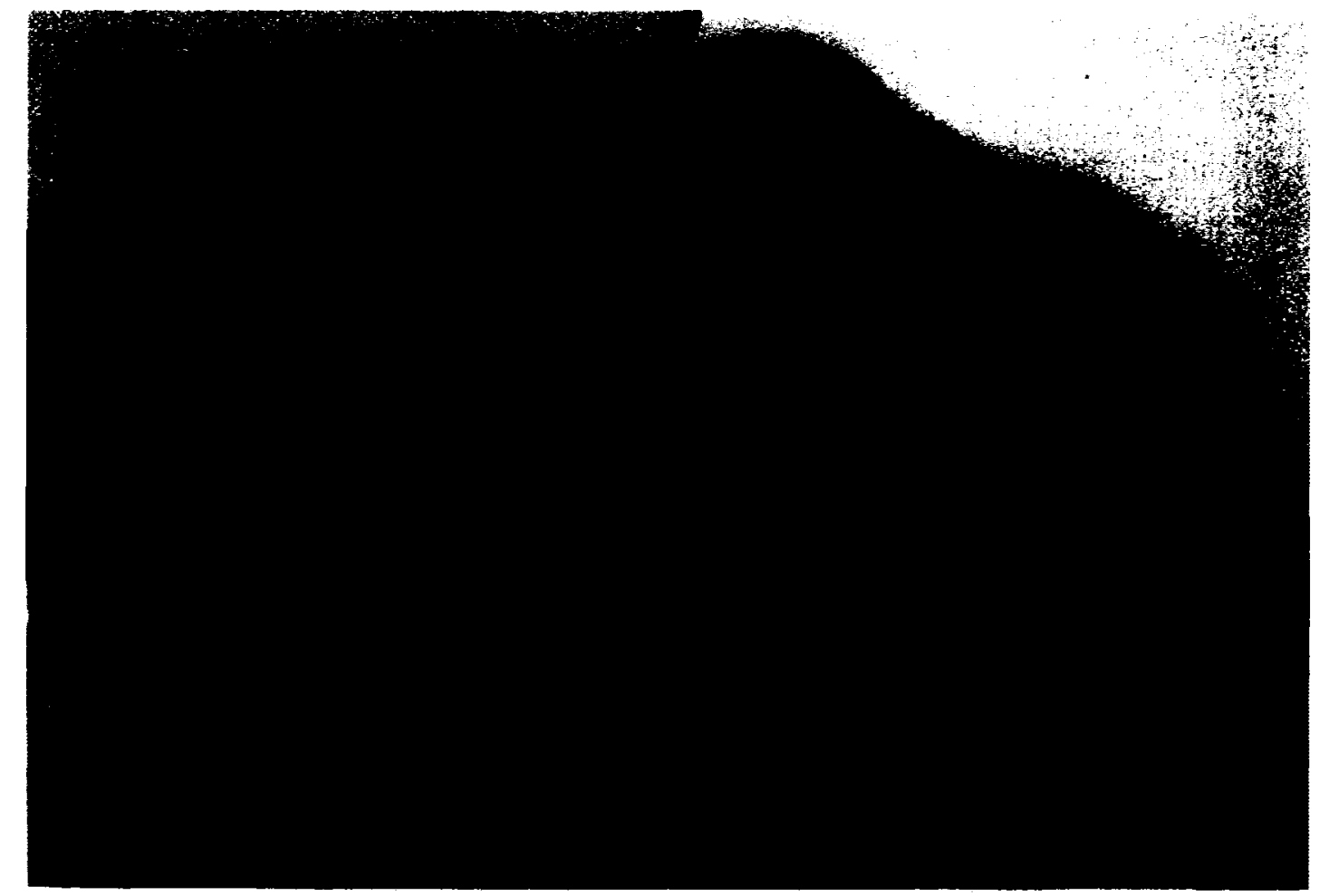

Figure1.1

Artist in Union with Mother Earth

1972

$77.5 \mathrm{~cm} \times 116.8 \mathrm{~cm}$

Acrylic on canvas

Private Collection M. Mason

Toronto, Ont. 


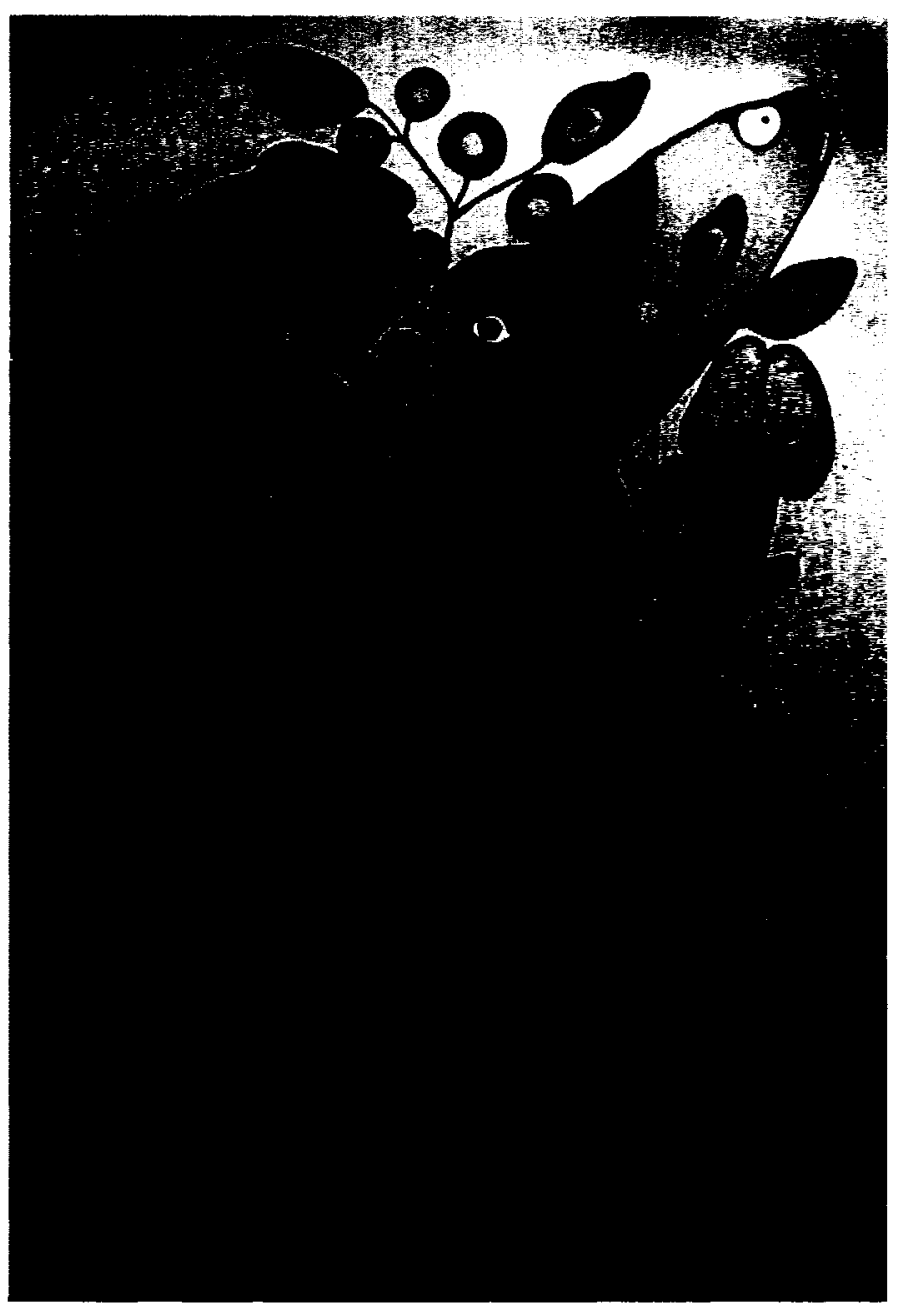

Figure1.2

Man and Woman

n.d.

$187.9 \times 137.2$

Acrylic and Canvas

Glenbow Museum Collection

Calgary, Alberta

986.226.16 


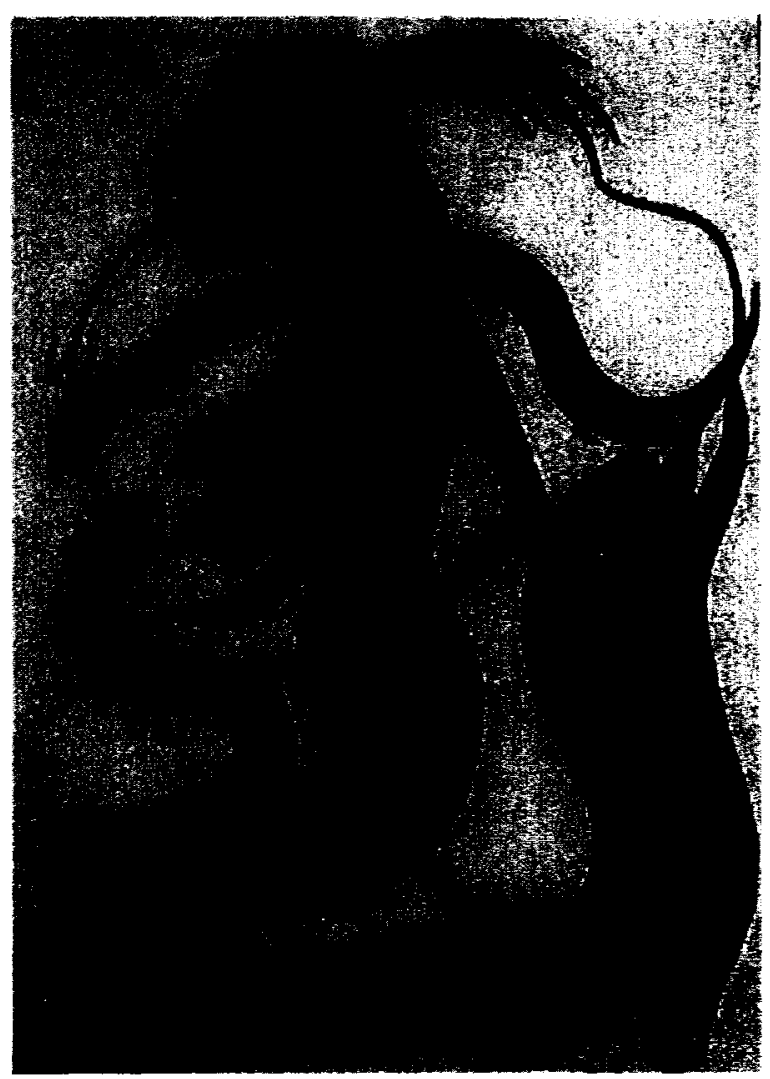

Figure 2.1

The Great Spent Mother: Mother of All Serpents

1972

$37.8 \times 50.2 \mathrm{~cm}$

Acrylic on paper

Royal Ontario Museum Collection 


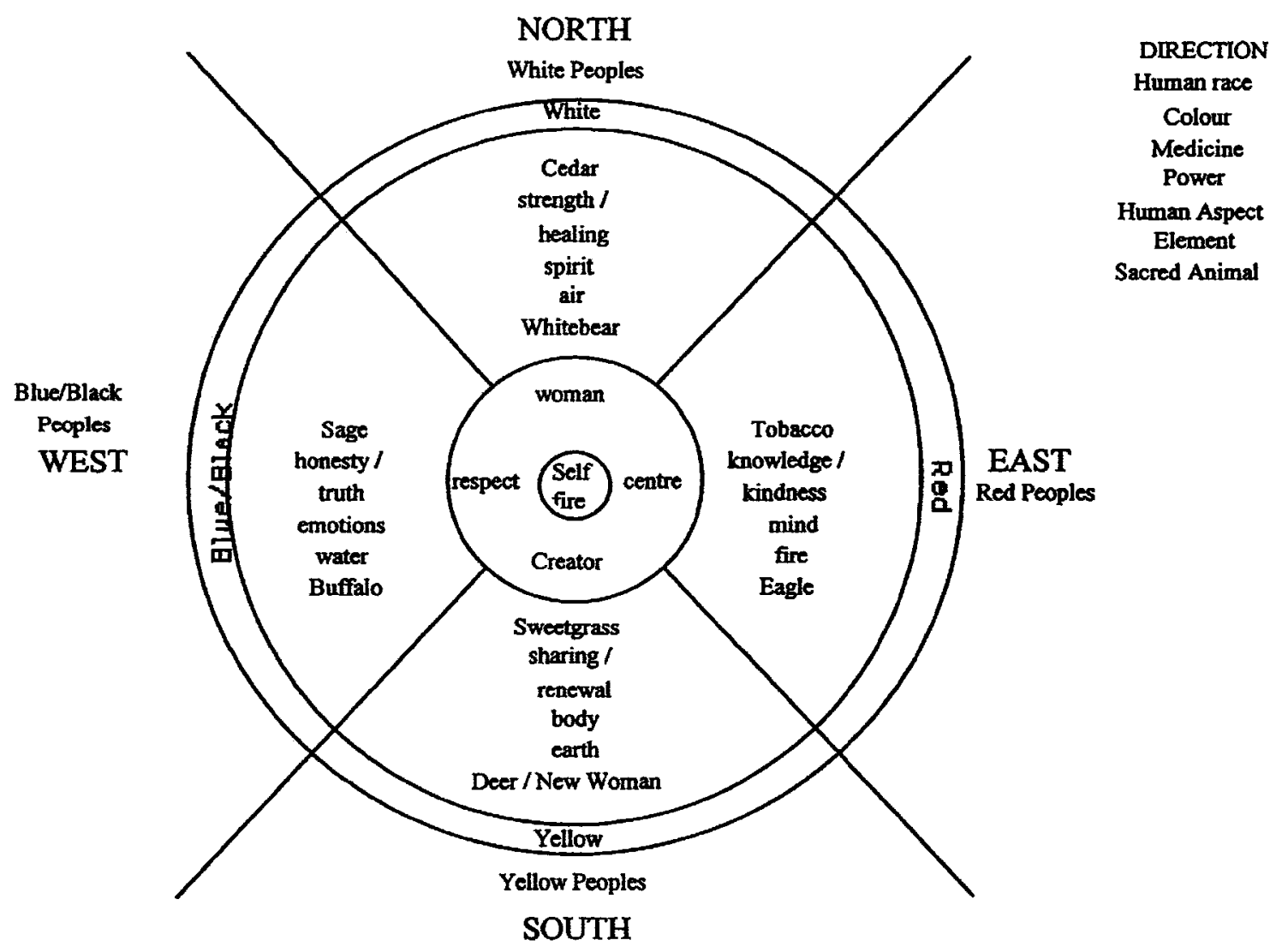

Figure 2.2

Medicine wheel

Reproduced From D'Arcy Rheault. Midéwiwin Organization of Knowledge Unpublished FC 500 Paper

Trent University, January 1997. 


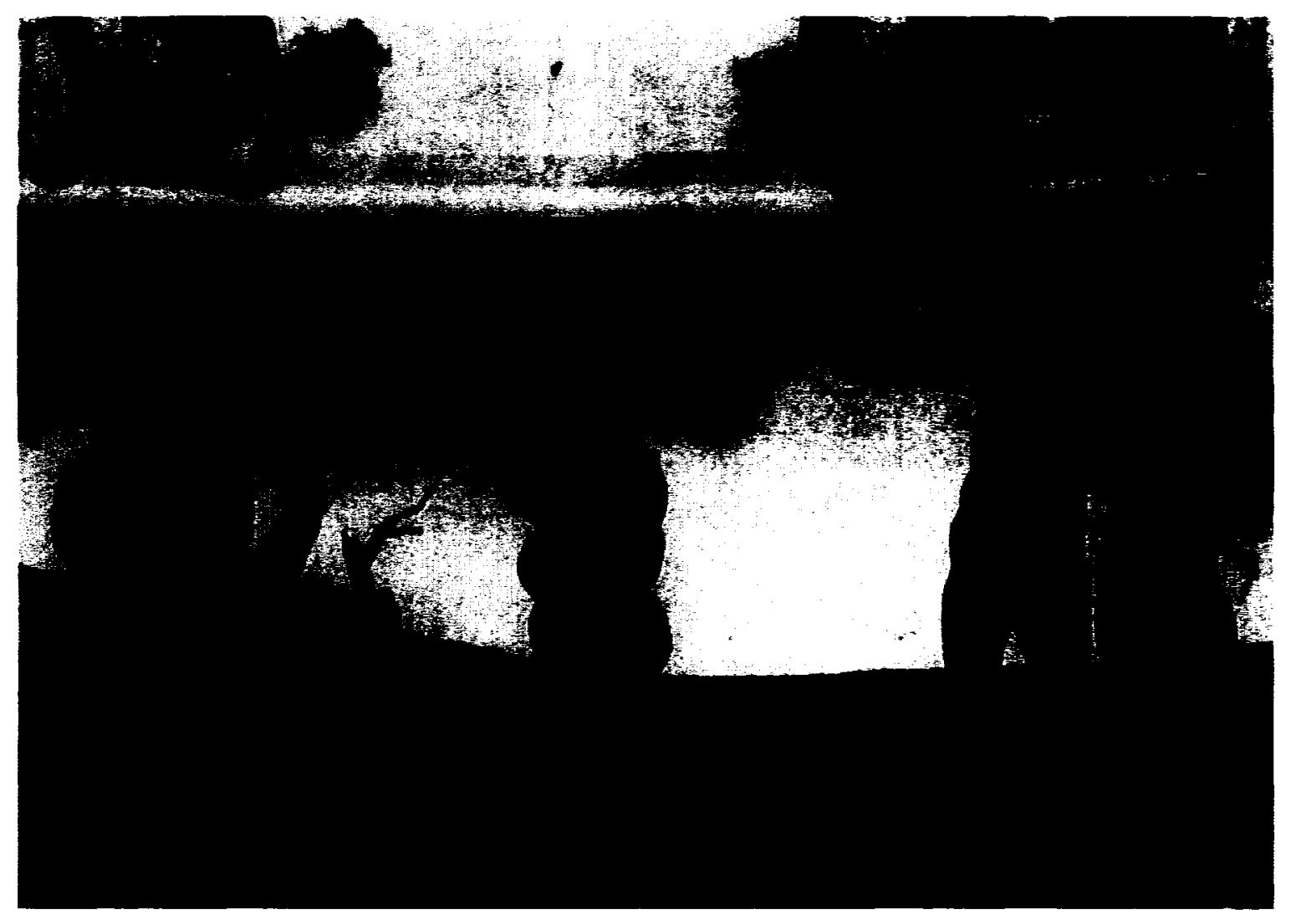

Figure 2.3

Temptation and Fall

1510

Fresco,

Michelangelo.

Sistine Chapel, Vatican, Rome 


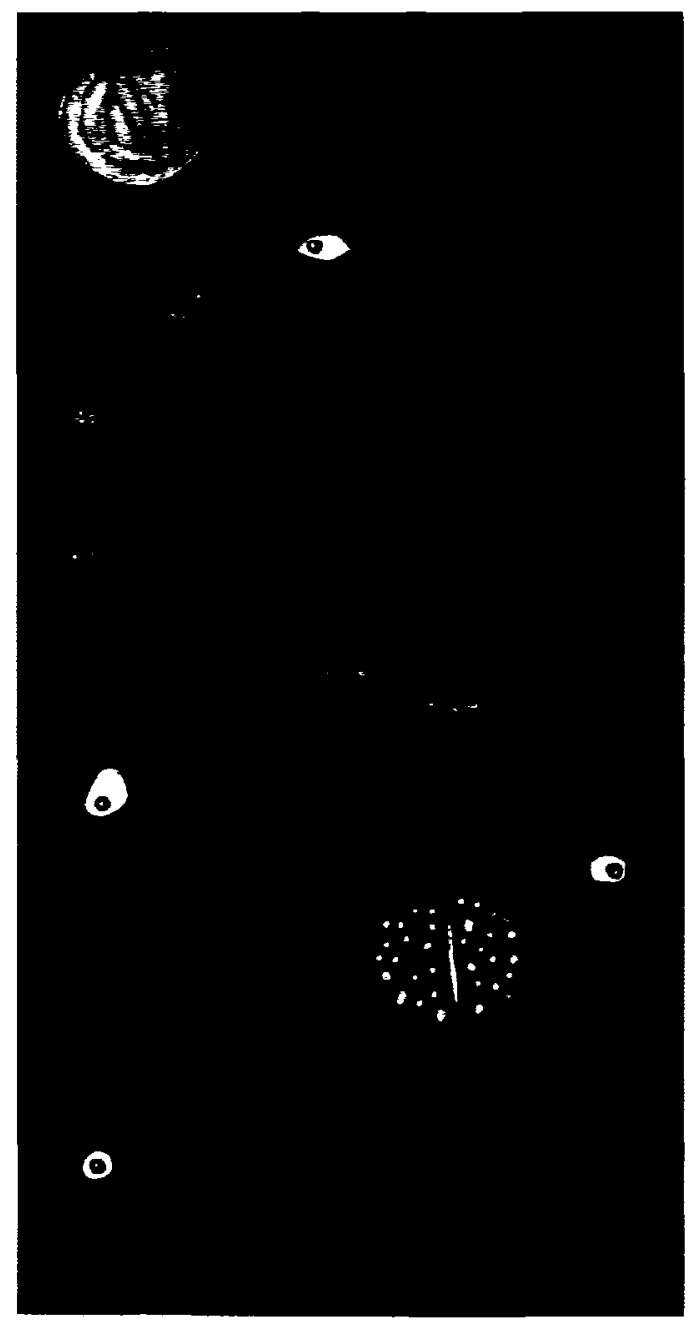

Figure 2.4 Mother Earth 1975

$203.2 \times 104 \mathrm{~cm}$ Acrylic on canvas Private Collection

Reproduced from Lister Sinclair and Jack Pollock The Art of Norval Morrisseau. Page 124 


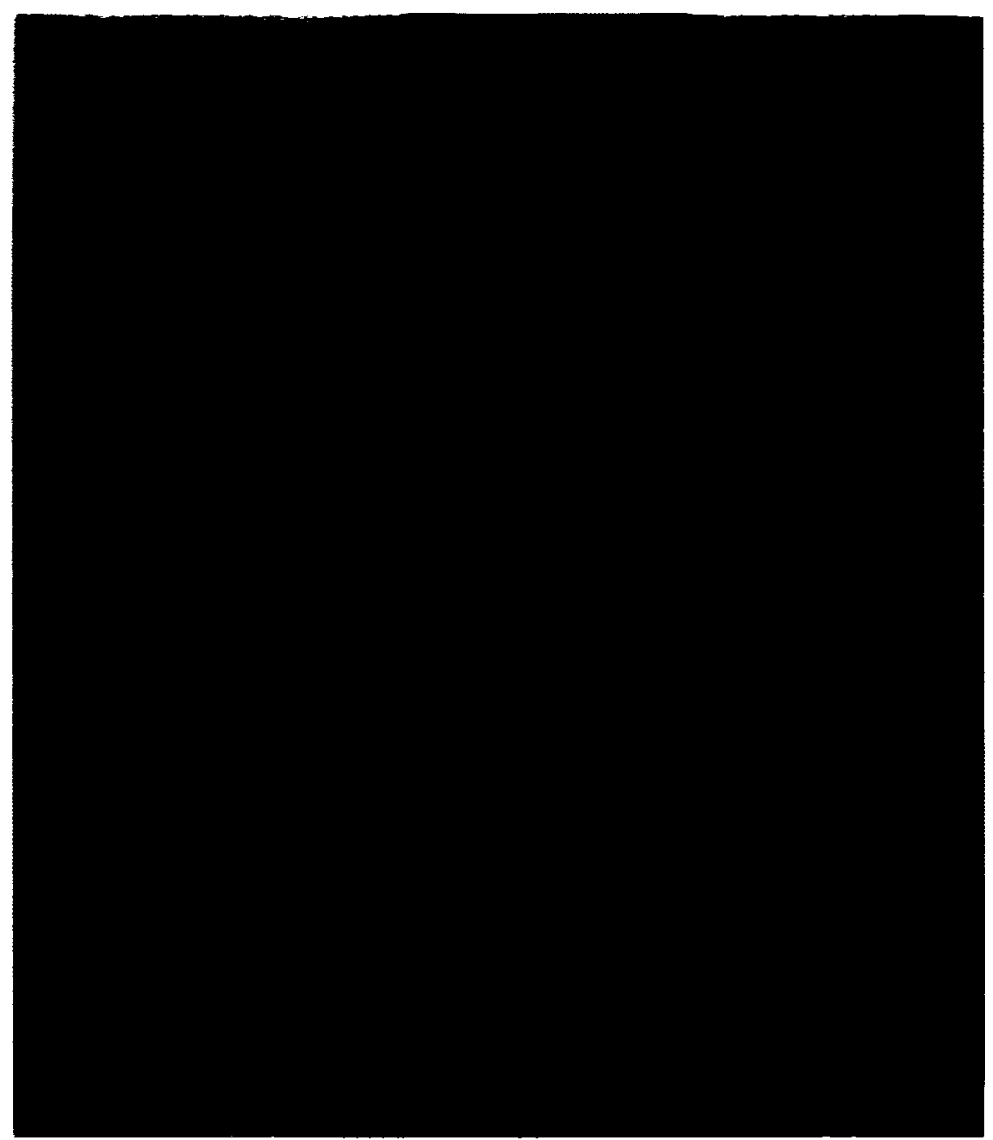

Figure 2.5

Virgin Mary with Christ Child and St. John the Baptist

1973

$101.6 \mathrm{~cm} \times 81.3 \mathrm{~cm}$

Acrylic on Canvas

Department of Indian Affairs Indian Art Centre

Reproduced from the book The Art of Norval Morrisseau. Page 101 


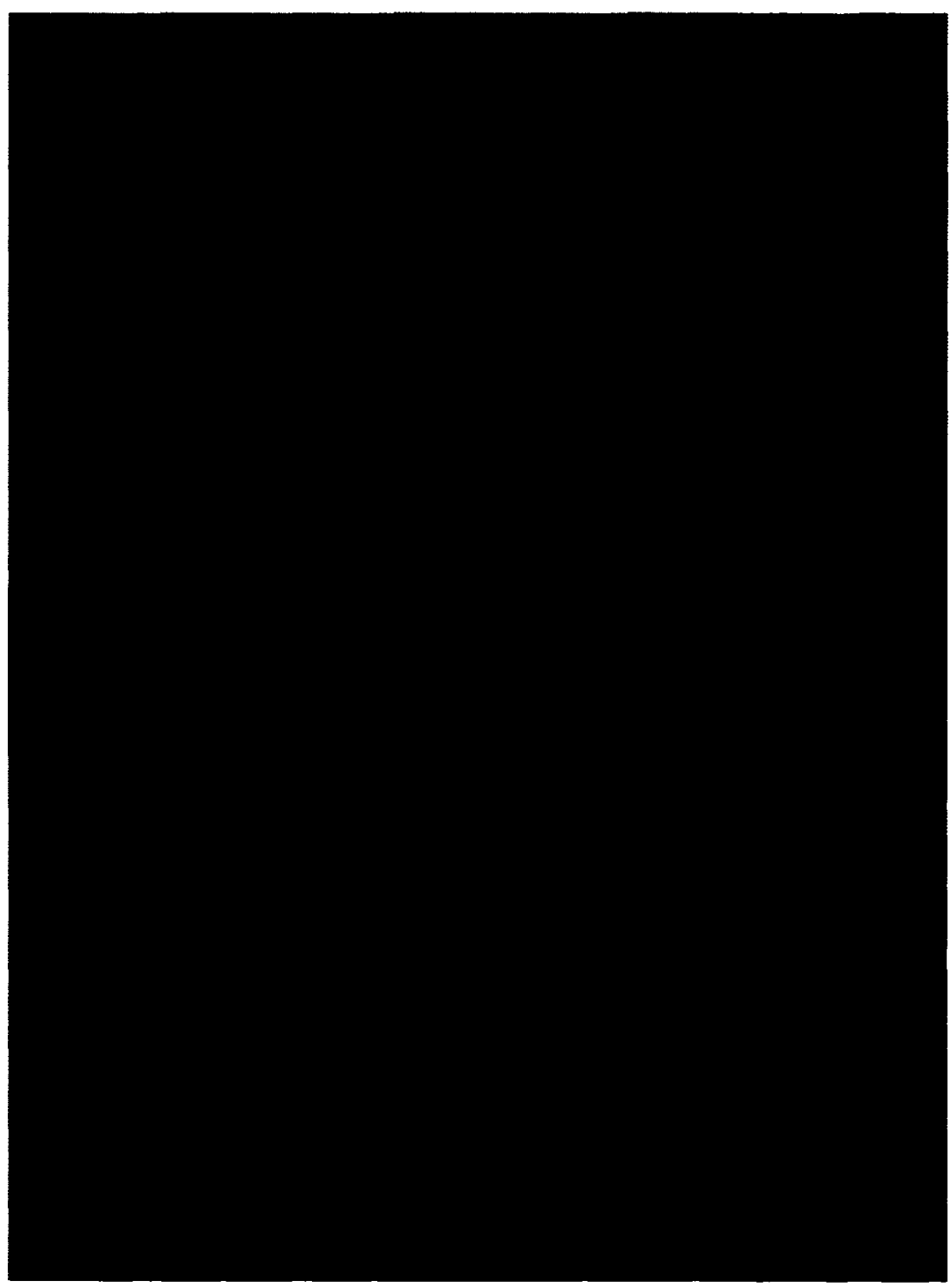

Figure 2.6

Artist Wife and Daughter 1975

$101.6 \mathrm{~cm} \times 81.3 \mathrm{~cm}$

Acrylic on masonite

The McMichael Collection

Kleinburg, Ontario

Reproduced from the book The Art of Norval Morrisseau. Page 123 


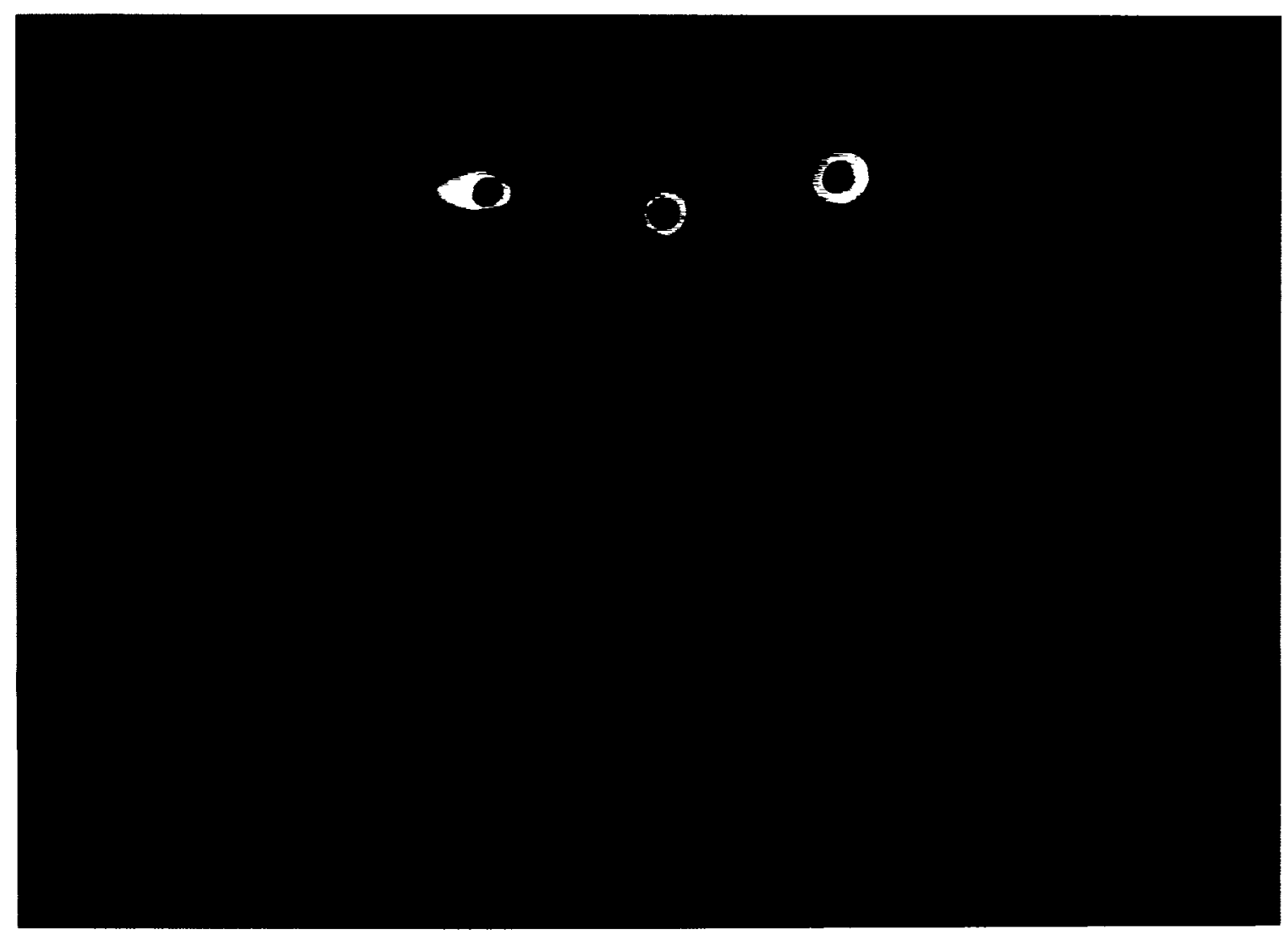

Figure 2.7

Woman

Circa 1960

Acrylic on canvas

Reproduced from the exhibition catalogue

Norval Morrisseau and the Development of Woodland School of Painting

Maslak McCleod Gallery 2000. Page 17 


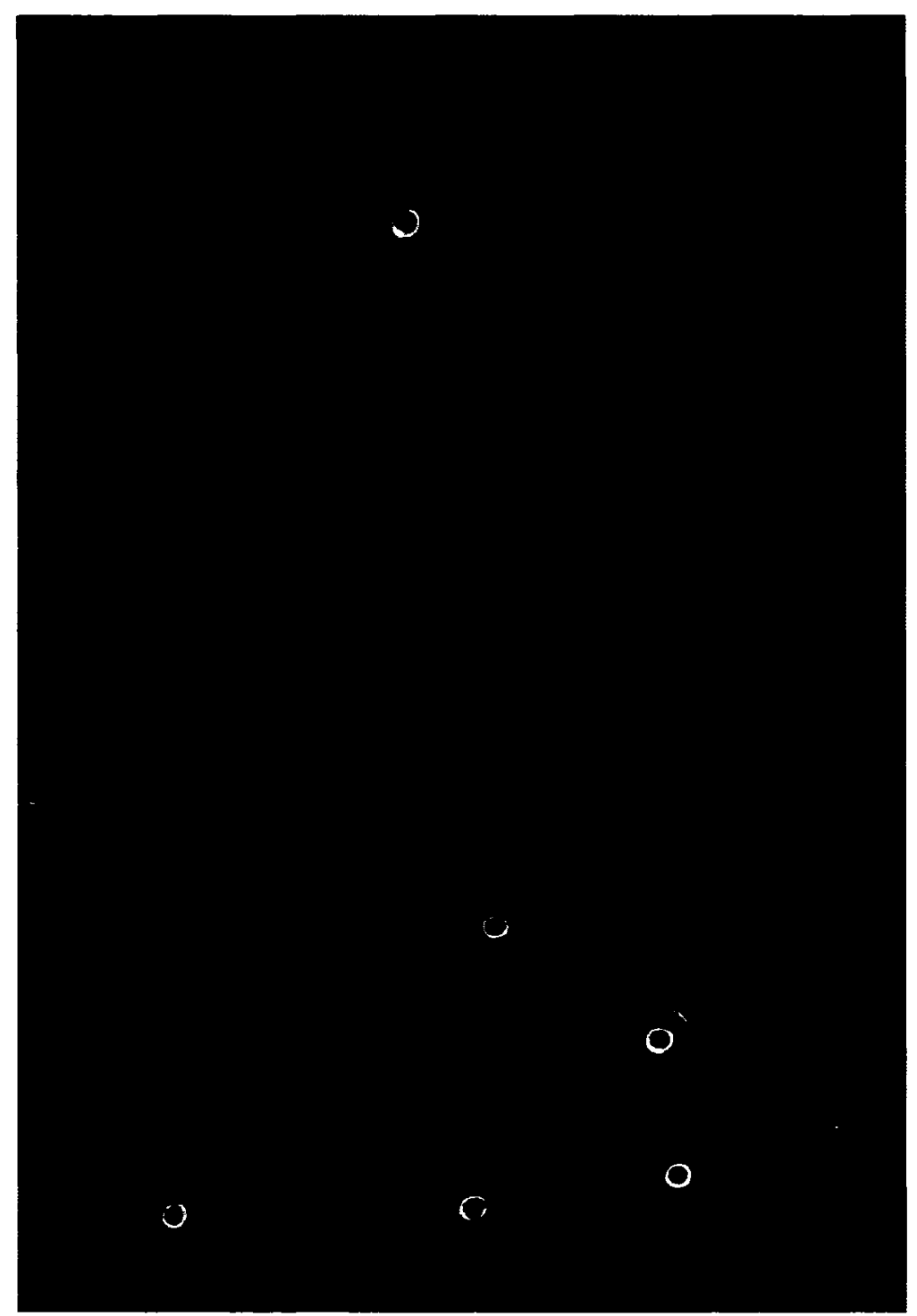

Figure 3.1

Self Portrait of Indian Artist

1985

Acrylic on canvas

Art Gallery of Hamilton Collection

85MOR114 \#87 


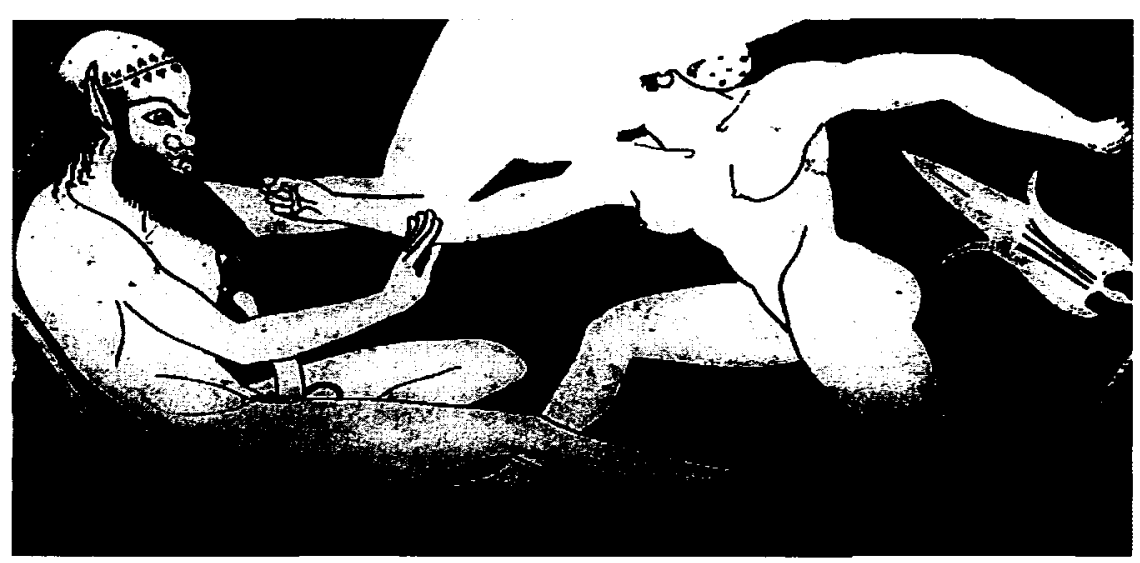

Figure 3.2

Phintias Satyr and Nymph

c510

Detail of red figure cup

Badisches Landesmuseum, Karlsruhe

Reproduced from Abigial Solomon-Godeau's Male Trouble: A Crisis in Representation. Page 181 


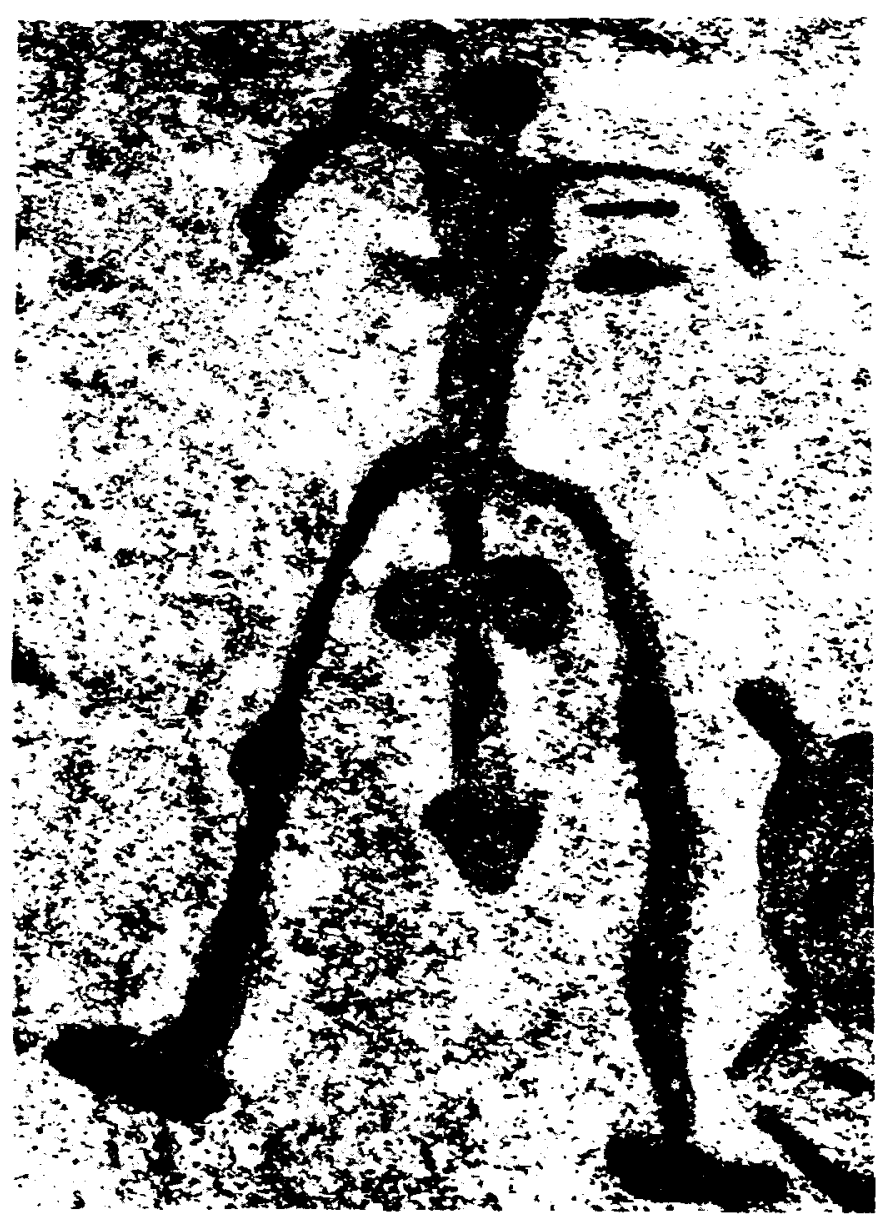

Figure 3.3

Phallic Figure

Petroglyph

n.k.

Reproduced from the book Sacred Art of the Algonkians: A Study of the

Peterborough Petroglyphs

by Joan and Romas Vasokas

Page 84 


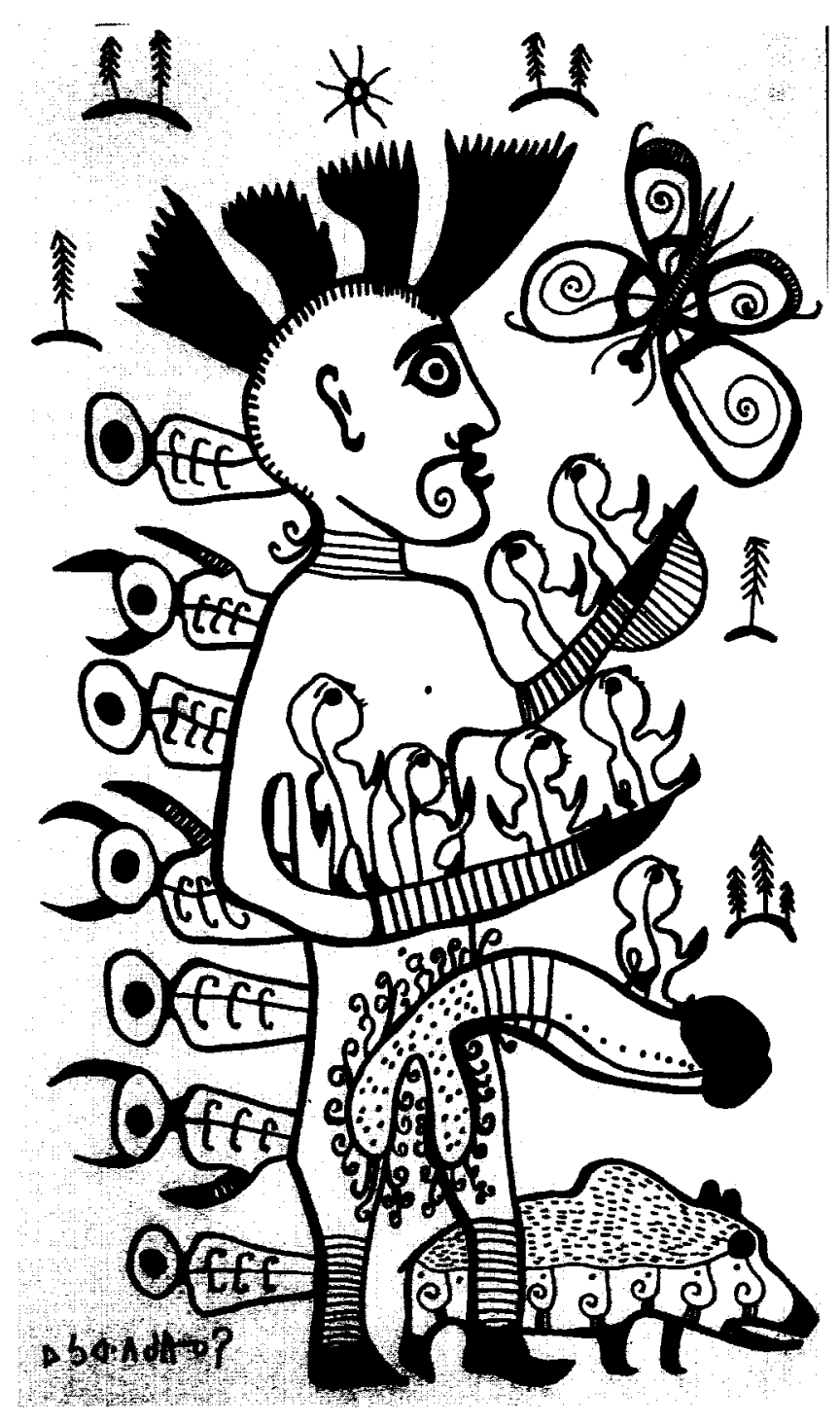

Figure 3.4 Untitled 1990's n.k. Ink on paper

Private Collection of Gabor and Michele Vadas Nanaimo, B.C. 

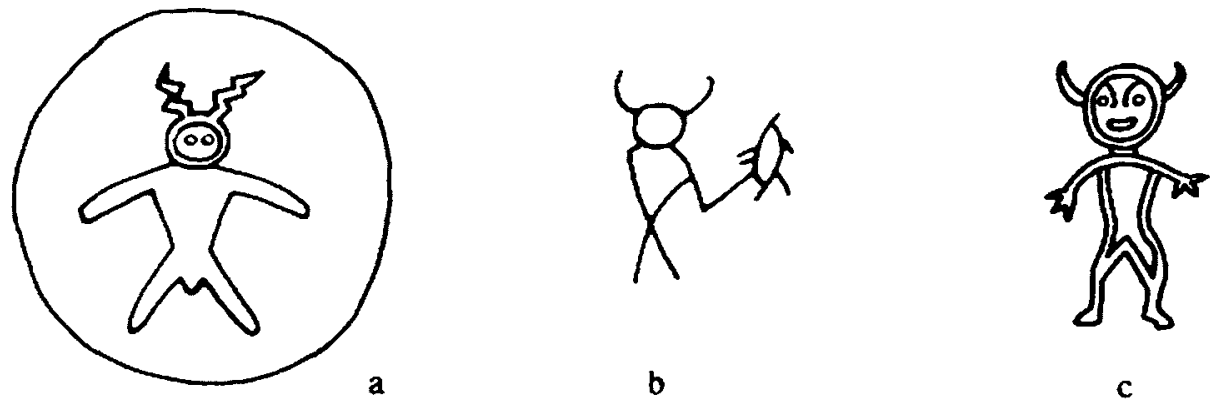

c

Figure 3.5

Petroglyphs

Shaman

n.k.

from the book Sacred Art of the Algonkians: A Study of the Peterborough

Petroglyphs

by Joan and Romas Vasokas

Page 91 


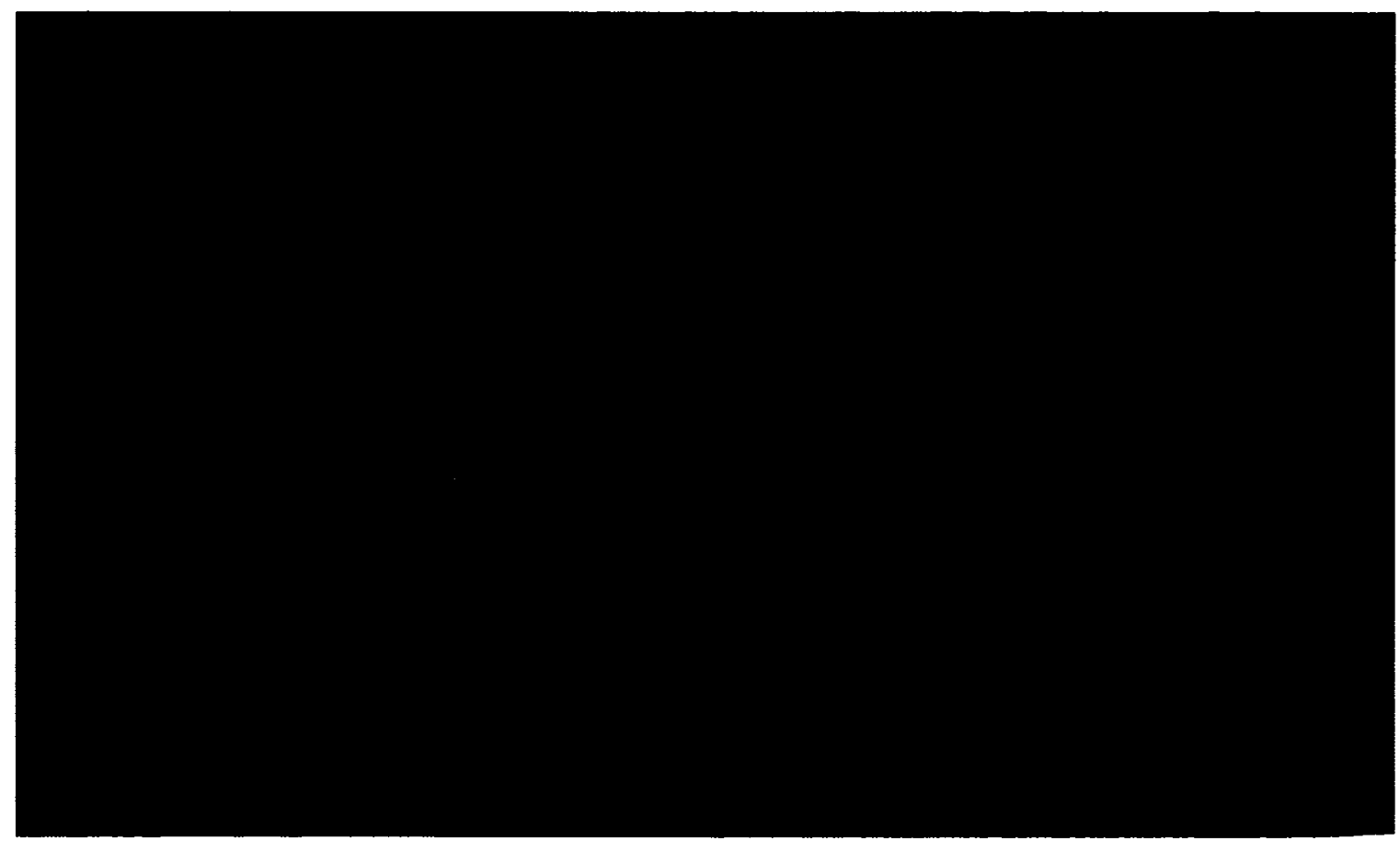

Figure 3.6

Man Changing into Thunderbird

1958-60

$63 \mathrm{~cm} \times 101.3 \mathrm{~cm}$

Watercolour and ink on birch bark

Canadian Museum of Civilization

Hull, P.Q.

III-G-1099 


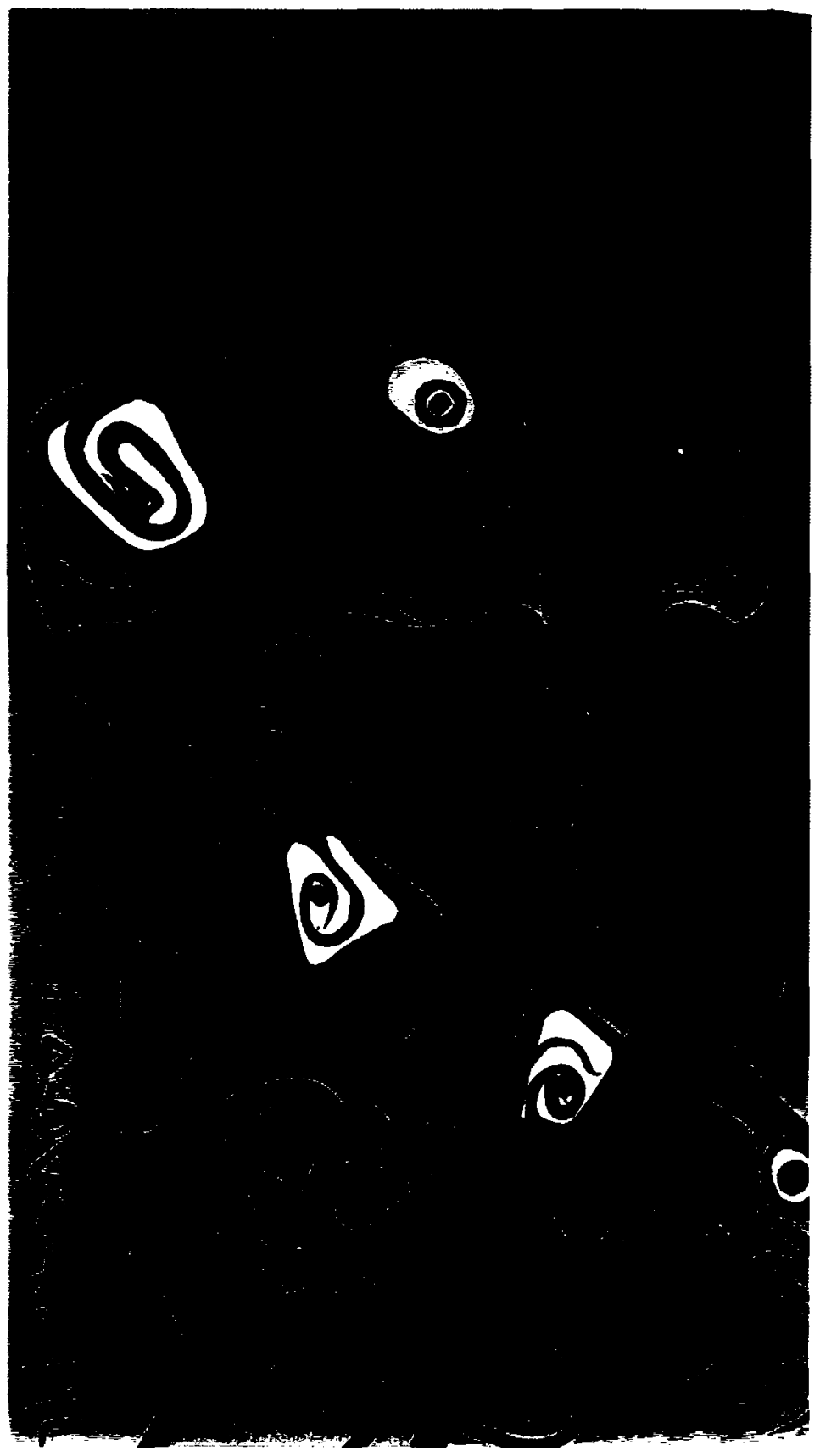

Figure 3.7

1972

Phallic God in Disguise

Acrylic on canvas

Reproduced from the book The Art of Norval Morrisseau

Page 69 


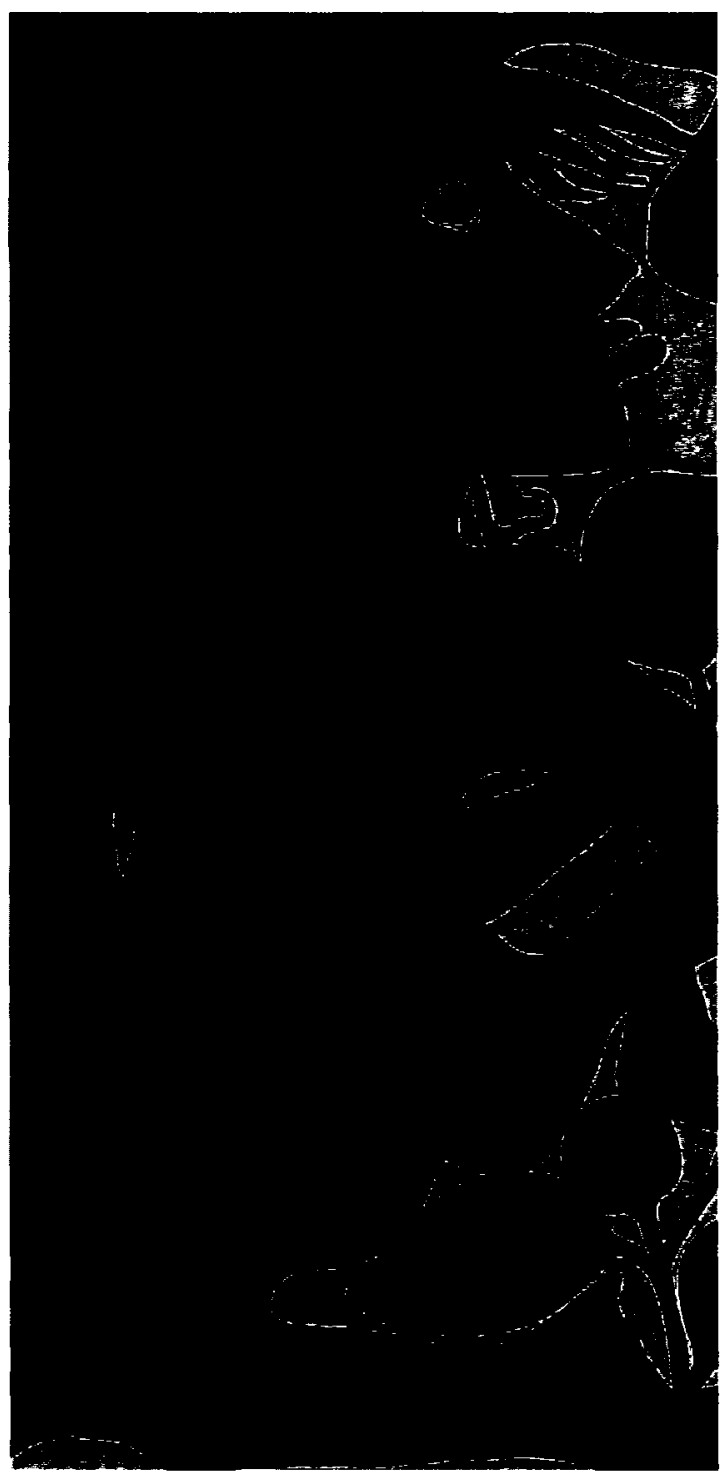

Figure 3.8

Untitled (detail)

n.k

Acrylic on canvas

Private Collection of Gabor and Michele Vadas Nanaimo, B.C. 


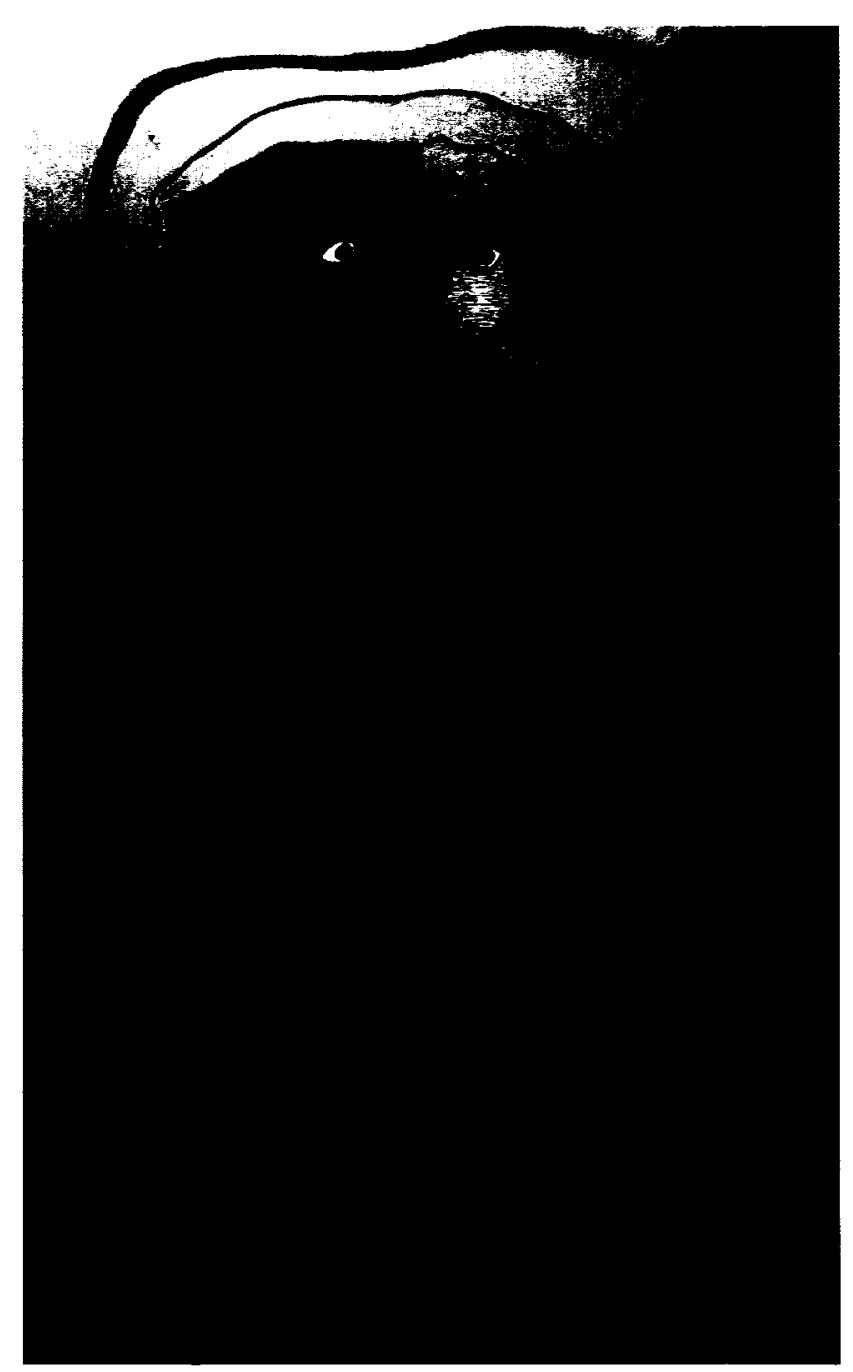

Figure 4.1

Indian Erotic Fantasy

n.d.

$257.8 \mathrm{~cm} \times 152.4 \mathrm{~cm}$

Acrylic on canvas

Glenbow Museum Collection

Calgary, Alberta

986.226.35 


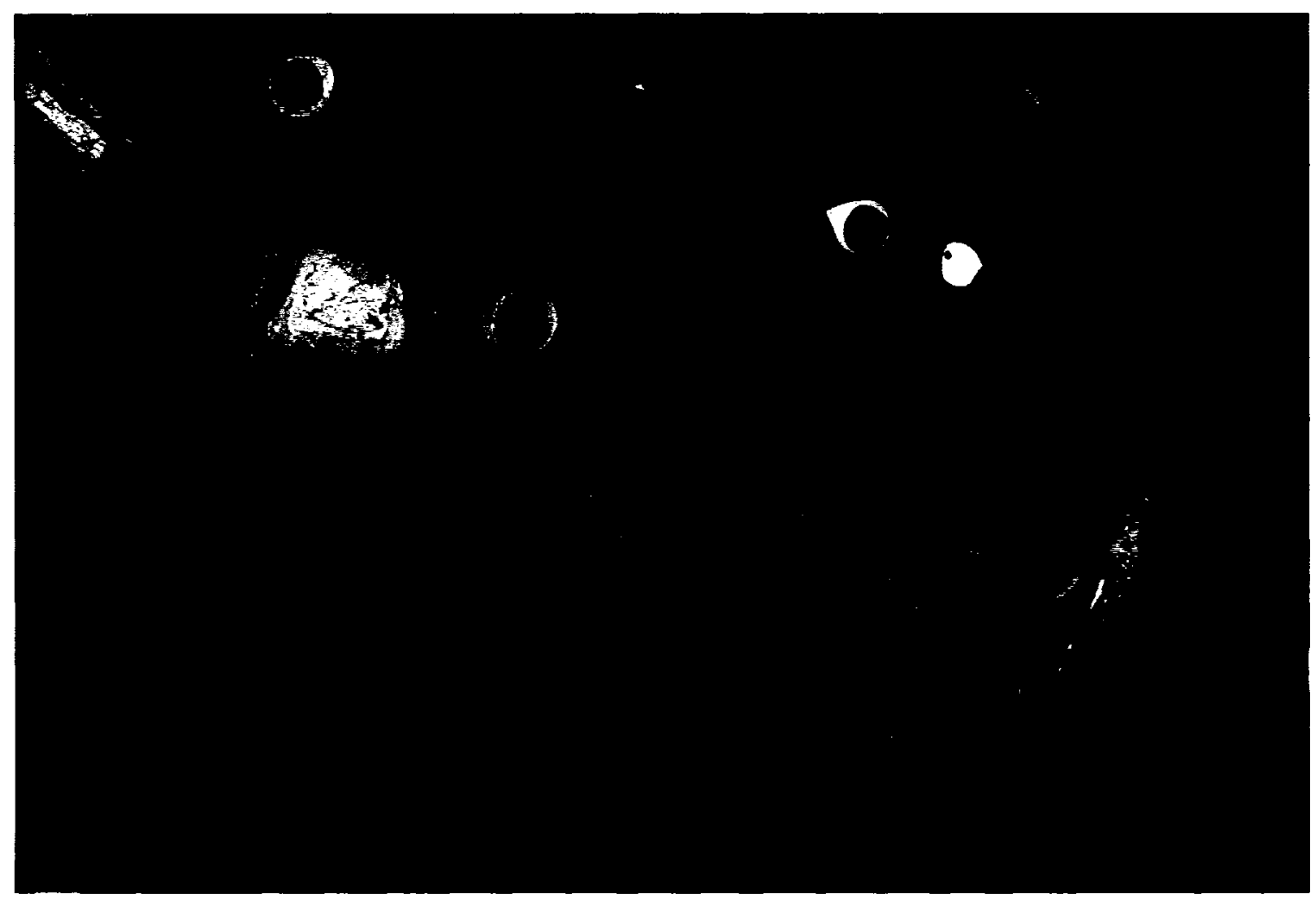

Figure 4.2

Life Figures

n.k.

Acrylic on canvas

Art Gallery of Hamilton

85MOR117 \#81 


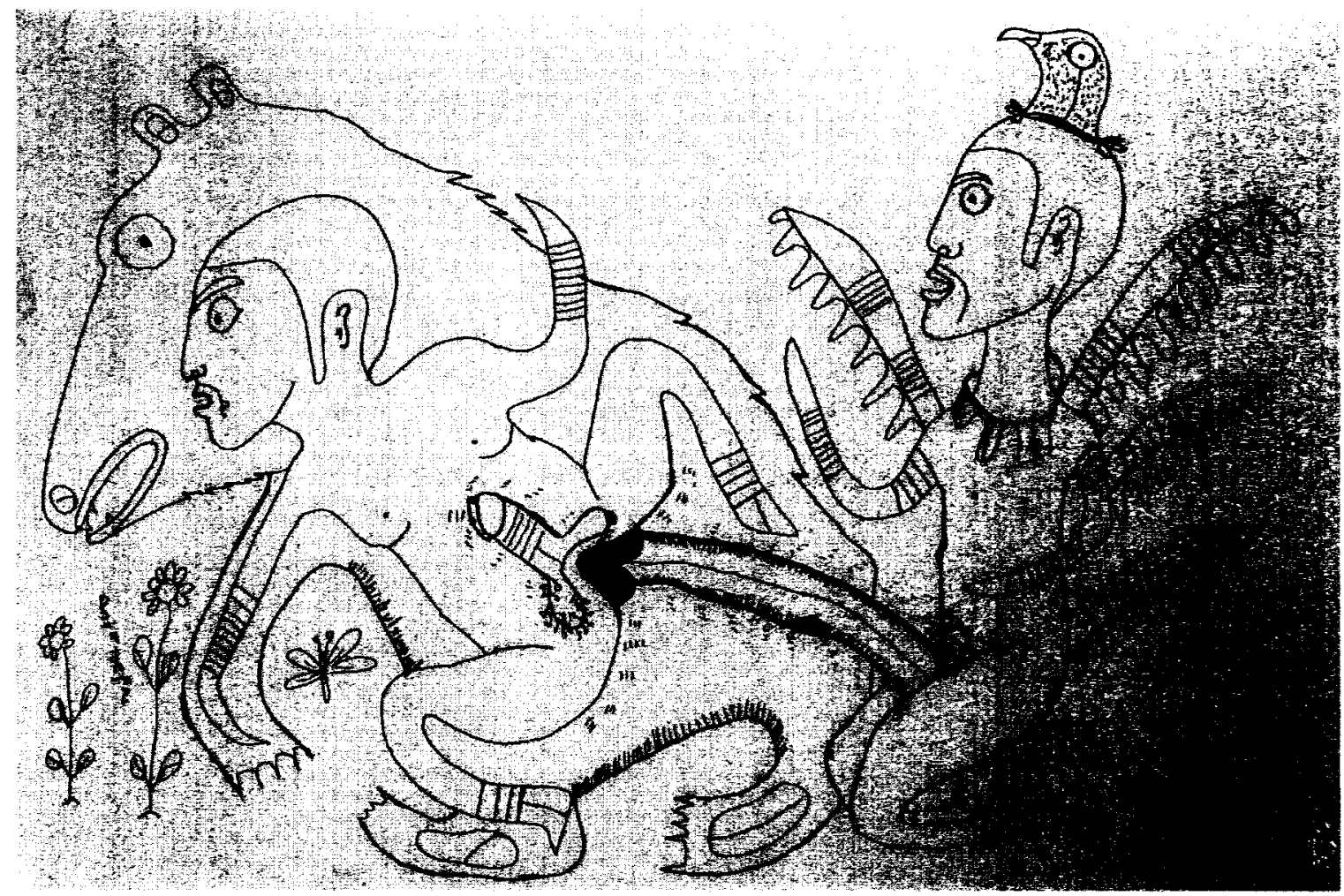

Figure 4.3

Untitled

1999

Ink on paper

Private Collection of Gabor and Michele Vadas

Nanaimo. B.C. 


\section{Bibliography}

Ballinger, Franchot. "Coyote, He/She Was Going There: Sex and Gender in Native American Trickster Stories." Studies in American Indian Literatures Series 2. Volume 12, Number 4 Winter 2000.

Barthes, Roland. Mythologies. 1957. London: Vintage. 1993.

Barnouw, Victor. "Wenebojo and the Chief's Son." Wisconsin Chippewa Myths and Tales And Their Relation to Chippewa Life. Madison: University of Wisconsin Press. 1977.

Benton-Banai, Edward. The Mishomis Book. St. Paul, MN. Indian Country Press. 1981.

Berger, John. The Art of Seeing, London: BBC/Pelican, 1972.

Butler, Judith. Gender Trouble: Feminism and the Subversion of Identity. New York: Routledge Press, 1999.

Callender, Charles and Lee M. Kochems. "The North American Berdache." Current Anthropology, 24:4, Aug-Sept 1998. 443-470.

Carvalho, Paul. A Separate Reality: The Life and Times of Norval Morrisseau. Perception Films INC. 2004.

Canadian Broadcast Corporation Archives. "Jailed for Homosexuality." Life and Society. Gay and Lesbian Emergence in Canada: Out in Canada.

http://archives.cbc.ca/IDC-1-69-599-3226/life_society/gay_lesbian/clip2 Accessed 04. 01.2006.

Clark, Kenneth. The Nude: A Study in Ideal Form, London, Murray,1956.

Collins, Curtis. Janvier and Morrisseau: Transcending a Canadian Discourse. M.A. thesis. Montreal, Concordia University. 1994.

Daniel, Ann. "Norval Morrisseau: Myth and Reality." The Challenge. Montreal. Dec 11, 1996.

Dickson, Olive. Indian Art in Canada, Ottawa: Department of Indian and Northern Development, 1972. 
Dieterle, Richard L. "The Tricksters Penis." The Encyclopedia of Hotcâk (Winnebago) Mythology. http://www.hotcakencyclopedia.com/ Accessed 10.12.2005.

Dijkstra, Bram. Idols of Perversity. Fantasies of Feminine Evil in Fin-de-Sielcle Culture. New York: Oxford University Press, 1986.

Doherty, Joanna. An Examination of the sources of Ojibwa and non-Ojibwa Elements in Norval Morrisseau's art. M.A. Thesis. Ottawa, Carleton University 1982.

Erodes, Richard and Alfonso Ortiz. "Old Coyote Man and Coyote Woman." American Indian Trickster Tales. New York: Penguin Books.1999. 61-63.

Fernander, Dominique. A Hidden Love; Art and Homosexuality. Prestel Verlag. English Edition 2002. 158-181.

Foucault, Michel. History of Sexuality: An Introduction, vol 1, translated from the French by Robert Hurley, New York: Vintage Books, 1990.

Grant Peter "The Sauteux Indians About 1804." In Les Bourgeois de la Compagnie du Nord- Quest Recits de Voyages, letters et rapports inedits relatifs au nord-ouest canadien. Vol.2, Ed. L.R. Masson, New York: Antiquarian Press. 306-66.

Grosz, Elizabeth. Sexual Subversions: Three French Feminists. Sydney: Allen \& Unwin Press,1989.

Hallowall, A. Irving. The Ojibwa of Berens River, Manitoba Ethnography into History. Ed. Jennifer H Brown. Toronto: Harcourt Brace College Publishers, 1992.

"Ojibwa Ontology, Behavior and Worldview." in Irving Hallowell Contributions to Anthropology. ed Stanley Diamond. Chicago: University of Chicago Press, 1976. 353-391.

Henry, Alexander. New light on the Early History of the Greater Northwest: the Manuscripts Journals of Alexander Henry and David Thompson, 1799-1814 Vol.1 Ed. Elliot Coues. New York: Frances P Harper.

Hill, Greg. A. "Norval Morrisseau: Shaman Artist." Norval Morriseau Shaman Artist. Ottawa: National Gallery of Canada. 2006. 
Hill, Tom and Elizabeth McLuhan. Norval Morrisseau and the Emergence of the Image Makers. Toronto: Art Gallery of Ontario, 1984.

Hume, Christopher. "The New Age of Indian Art." Maclean's Magazine. January 22, 1979.

Jacobs, Sue Ellen et al. Two-Spirit People: Native American Gender Identity, Sexuality and Spirituality. University of Illinois Press. Urbana and Chicago. 1997.

Johnston, Basil. Ojibway Heritage. Toronto: McClelland and Stewart Limited, 1976. of Indian Affairs, 1987. Ojibway Language Lexicon for Beginners. Ottawa. The Department The Manitous; The Spiritual World of the Objiway New York : HarperCollins Publishers, 1995.

Jones, Ameila. "Representation." Introduction to Part Two: in The Feminism and Visual Cultural Reader. London: Routhedge Press, 2003.

Landes, Ruth. Ojibwa Religion and the Midéwiwin. Madison: University of Wisconsin Press.1968.

1938. The Ojibway Woman. New York: Columbia University Press,

Lang, Sabine. "Various Kinds of Two-Spirit People: Gender Variance and Homosexuality in Native American Communities." Two - Spirited People: Native American Gender identity, Sexuality and Spirituality. Urbana:University of Illinois Press.1997.

Lewis Johnson, Jone. “Adrianne Rich Quotes." Women's History. http://womenshistory.about.com/cs/quotes/a/qu_adriennerich.htm Accessed 10.02.2006.

Lucie-Smith, Edward. Adam: The Male Figure in Art. Rizzoli. New York.1998

Mackinnon, Kenneth. Uneasy Pleasure: The Male as Erotic Object, London: Cygnus Arts of Golden Cockerel Press, 1997.

Martin, Lee Ann and Morgan Wood, Exposed: Aesthetics of Aboriginal Erotic Art. Regina. McKenzie Art Galley. 1999. 
Maslak McCleod Gallery, Norval Morrisseau and the Development of the Woodlands School of Art, 1960-1980. Toronto: 2002.

Merchant, Carolyn. The Death of Nature: Women, Ecology and the Scientific Revolution. San Francisco: Harper, 1980.

Morrisseau, Norval. Legends of My People: The Great Ojibway. Typed manuscript) Glenbow Museum Archive. Calgary, Alberta.

Legends of My People; The Great Ojibway. Handwritten

manuscript. Glenbow Museum Archives. Calgary, Alberta.

Artist Files. National Gallery of Canada. Ottawa

McLuhan, Elizabeth and Tom Hill. Norval Morrisseau and Emergence of the Image Makers. Toronto: Methuen, 1984

Mulvey, Laura. "Visual Pleasure in Narrative Cinema" in The Feminism and Visual Cultural Reader. Ed. Amelia Jones. London: Routhedge Press, 2003, Pages 44-52

Nead, Lynda. Female Nude; Art, Obscenity and Sexuality. London: Routledge Press, 1992.

Overholt, Thomas and J Baird Callicott. Clothed -In - Fur and Other Tales: An Introduction to a Ojibwa Worldview. Washington, D.C.: University Press of America, 1982.

Paper, Jordon. "Through the Earth Darkly: The Female Sprit in Native American Religions." in Religion In Native North America. Ed. Christopher Vecsey Moscow, Idaho: University of Idaho Press, 1990.

Paterson ,Nancy Lou. "Shaking Tents and Medicine Snakes: Traditional Elements in Contemporary Woodland Indian Art." Artsmagazine. Summer 1976.

Phillips, Ruth. B. “Morrisseau's Entrance: Negotiating Primitivism, Modernism and Anishnaabe Tradition." Ed. Greg Hill. Norval Morrisseau: Shaman Artist. Ottawa: National Gallery of Canada. 2005.

"Invoking Magic; Norval Morrisseau Art and Discursive Constructions of Art, Anthropology and the Postcolonial." Eds. Brigitte Derlon and Michele Coquet. Anthropologie, Objets, et Esthetiques, Paris: Centre National de Recherche Scientifique. 2005 
Plato. Symposium.Translated by BejaminJowett.

http://classics.mit.edu/Plato/symposium.html. Accessed 10.12.2005.

Plumwood, Val. Feminism and the Mastery of Nature. London: New York: Routledge,1993.

Pollock, Griselda "Screening the Seventies." In The Feminism and Visual Cultural Reader. Ed. Amelia Jones. London: Routhedge Press, 2003, 81-93.

Radin, Paul. Winnebego Hero Cycles: A Study in Aboriginal Literature.

Baltimore, Indiana: Waverly Press. 1948.

Rheault, D'Arcy. Midéwiwin Organization of Knowledge. Peterborough: Trent University FC. 500 Unpublished paper.1997.

Roscoe, Will. Changing Ones: Third and Fourth Genders in Native North America. New York: St Martin's Press. 1998

Robinson, Donald. Norval Morrisseau Honoring First Nations. Toronto: Kinsman Robinson Gallery. 1994. "Tales of Copper Thunderbird." Norval Morrisseau Travels to the House of Invention. Toronto: Key Porter. 1997.

Ruffo, Armand "Norval Morrisseau: Man Changing into Thunderbird," in Norval Morrisseau: Shaman Artist. Ed. Greg Hill. Ottawa: National Gallery of Canada. 2006.

Sagi, Douglas. " 'Pulling Images Out of the Bear.' Recent Paintings: Norval Morrisseau." The Art Emporium Exhibition Review. Artists Files National Gallery of Canada.

Schick, Irvin C. The Erotic Margin: Sexuality and Spatiality in Alteritist Discourse. London: Verso.1999.

Sedgwick Kosofsky Eve. Epistemology of the Closet. Berkeley: University of California Press, 1990.

Shuler, Bobbalee Ann. More Sin than Pleasure: A Study in Cultural Conflict. Unpublished PhD dissertation. History. University of Wyoming. 1994.

Sinclair, Lister and Jack Pollock. The Art of Norval Morrisseau. Toronto: Methuen Publications, 1979.

Smalls, James. Homosexuality in Art. Parkstone Press, New York. 2003. 
Solomon-Godeau, Abigail. Male Trouble: A Crisis in Representation. London: Thames and Hudson. 1997.

Southcott, Mary E. The Sound of the Drum; The Sacred Art of the Anishnabec. Erin: Boston Mills Press, 1984.

Stephens, James. "Interview with Norval Morrisseau." Art Magazine. 5:18. 1974.

Stoler, Ann Laura. Race and the Education of Desire: Foucault's History and the Colonial Order of Things. Durham: Duke University Press, 1995.

Tanner, John. A narrative of the captivity and adventures of John Tanner (U.S. interpreter at the Saut de Ste. Marie) during thirty years residence among the Indians in the interior of North America / prepared for the press by Edwin James. Minneapolis, MN: Ross and Haines, 1956.

Transcripts of sound roll four, Norval Morrisseau Artist Files, National Gallery of Canada

"The Pride of Norval Morrisseau." Weekend Magazine. July 29. 1979.

Vastokas, Joan and Romas Vastokas. Sacred Art of the Algonkians; A Study of the Peterborough Petroglyphs. Peterborough: Mansard Press. 1973.

Wissler, Clark. and D.C. Duvall. Mythology of the Blackfoot. Lincoln: University of Nebraska Press. 1995 